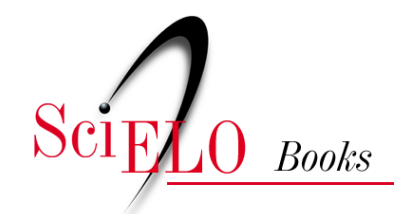

\title{
A família real no Brasil política e cotidiano (1808-1821)
}

\author{
Juliana Gesuelli Meirelles
}

MEIRELLES, J.G. A família real no Brasil: política e cotidiano (1808-1821) [online]. São Bernardo do Campo: Editora UFABC, 2015, 91 p. ISBN: 978-85-68576-96-0.

https://doi.org/10.7476/9788568576960.

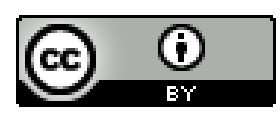

All the contents of this work, except where otherwise noted, is licensed under a Creative Commons Attribution 4.0 International license.

Todo o conteúdo deste trabalho, exceto quando houver ressalva, é publicado sob a licença Creative Commons Atribição $\underline{4.0}$.

Todo el contenido de esta obra, excepto donde se indique lo contrario, está bajo licencia de la licencia $\underline{\text { Creative Commons }}$ $\underline{\text { Reconocimento } 4.0 .}$. 
A Família Real no Brasil

política e cotidiano (1808 - 1821) 


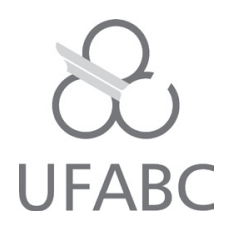

UNIVERSIDADE FEDERAL DO ABC

Prof. Dr. Klaus Werner Capelle - Reitor

Prof. Dr. Dácio Roberto Matheus - Vice-Reitor

\section{Editora da UFABC}

Profa. Dra. Adriana Capuano de Oliveira - Coordenação

Cleiton Fabiano Klechen

Marco de Freitas Maciel 


\section{Juliana Gesuelli Meirelles}

\section{A Família Real no Brasil política e cotidiano (1808 - 1821)}

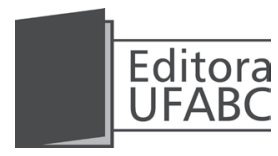

São Bernardo do Campo - SP 2015 
(c) Copyright by Editora da Universidade Federal do ABC (EdUFABC)

Todos os direitos reservados.

\section{Produção editorial}

Maíra Nassil

Capa e projeto gráfico

Ana C. Bahia

\section{Diagramação}

Luisa Helena Ribeiro

\section{Revisão de textos}

Lucas Morais

\section{Impressão}

Gráfica e Editora Copiart

CATALOGAÇÃO NA FONTE

SISTEMA DE BIBLIOTECAS DA UNIVERSIDADE FEDERAL DO ABC Responsável: Roberta Kelly Amorim de França CRB: 7660

981.03

MEIRf

MEIRELLES, Juliana Gesuelli

A família real no Brasil : política e cotidiano (1808-1821) /

Juliana Gesuelli Meirelles — São Bernardo do Campo: EdUFABC, 2015.

$92 \mathrm{p}$.

ISBN: 978-85-68576-26-7

1. História do Brasil 2. Corte Portuguesa no Brasil - política e sociedade 3. Corte Portuguesa no Brasil - reestruturação administrativa da corte I. MEIRELLES, Juliana Gesuelli. 


\section{SUMÁRIO}

INTRODUÇÃO 7

I A CHEgADA DA FAMÍLIA REAL E AS MUDANÇAS SOCIOPOLÍTICAS 9

II Sociabilidade e Conflito no Rio de Janeiro joanino 35

III A elevação do Brasil a Reino Unido e a Aclamação de D. JoÃo VI 43

IV Revolução do Porto e a volta da Família Real para Portugal 55

Considerações Finais 79

Bibliografia Comentada 81

Fontes E RefERÊNCIAS Bibliográficas 87 


\section{INTRODUÇÃO}

A vinda da Corte portuguesa para o Brasil aconteceu em meio a uma conjuntura política europeia muito delicada: as guerras napoleônicas que assolavam a paz no Velho Mundo (1805-1815). Nesse período, Napoleão não apenas destituiu dinastias e refez o mapa da Europa, como também insuflou um povo inteiro com a mística da nação. Já nos territórios conquistados, implantou uma série de valores da Revolução Francesa, cuja contribuição foi decisiva para o nascimento da política no sentido moderno.

O Bloqueio Continental decretado por Bonaparte, em novembro de 1806, tinha como meta o enfraquecimento da economia inglesa, um obstáculo fundamental aos objetivos expansionistas da França. O bloqueio exigia - sob ameaça de invasão militar - que todos os países da Europa se fechassem ao comércio britânico a fim de que a economia inglesa entrasse em colapso. Se o Acordo de Tilsit, firmado com o Czar Alexandre I da Rússia em julho de 1807, garantia a Napoleão o encerramento do extremo leste da Europa, era mister a conquista a oeste, que circunscrevia os portos das cidades de Lisboa e do Porto.

Portugal, porém, encontrava-se em uma situação deveras complexa. Se, por um lado, em setembro de 1807 , dom João acatava as ordens de Napoleão, fechando os portos aos navios ingleses - o que consolidava a ruptura com a Inglaterra -, por outra via, postergava na prática tal atitude, uma vez que mantinha com a Inglaterra uma relação de grande dependência econômica, que o impedia de acatar integralmente as ordens francesas. A forte aliança com os ingleses colocava a situação do país em xeque.

Portanto, fez-se urgente uma tomada de posição, sobretudo depois do ultimato de Napoleão que, em outubro de 1807 , ordenava a invasão francesa em território luso. À "medida que os rumores [da invasão] cresciam, ao longo de novembro de 1807 , o governo português buscou entabular negociações com a Inglaterra, através de uma convenção secreta, em que se previa a transferência da Família Real para o Brasil, protegida pela esquadra britânica, em troca da ocupação da Ilha da Madeira, enquanto perdurassem as operações militares no continente", contextualiza a historiadora Lúcia Neves (2008: 56).

Foi diante dessa crise geopolítica do continente europeu que a Dinastia de Bragança - com D. Maria I, o Príncipe Regente dom João e grande parte da Corte portuguesa -, embarcou para o Brasil, em 29 de novembro de 1807. No dia seguinte, as tropas francesas, sob a liderança de Junot, entravam em território português. Pouco mais de três meses depois, a realeza pisava em solo fluminense. 
A transferência da Família Real para o Brasil não foi uma medida tomada às pressas. Ao contrário, já era um projeto político arquitetado pela monarquia portuguesa desde o século XVI, que ganhava força sempre nos momentos de instabilidade política da Coroa (Schwarcz, 2002: 194-197). Em 1808, por fim, os planos de transladação do governo português para a sua mais importante colônia se tornavam realidade: o Rio de Janeiro emergia como nova capital do Império Português, impulsionando, dessa forma, transformações políticas de grande impacto nos dois lados do Atlântico durante os treze anos em que a Família Real permaneceu em nossas terras.

As guerras napoleônicas (1808-1815), o fim do apogeu de Bonaparte com a restauração do Antigo Regime na Europa (1815), a elevação do Brasil a Reino Unido de Portugal e Algarves (1815), a Revolução Pernambucana como um movimento contestatório ao poder absoluto de dom João (1817), a aclamação de dom João VI no Brasil (1818), a Revolução do Porto e as consequências desse processo com a volta do Rei à Europa (1820-1821) todos esses fatos históricos, descritos e analisados neste livro, foram cruciais nas grandes mudanças que delineavam a nova ordem política no jogo das relações luso-brasileiras.

Este livro trata especificamente das interfaces entre a política e o cotidiano no Rio de Janeiro no período joanino em meio a tantas transformações políticas e aos muitos conflitos e desafios da nova sociedade que se formava nos trópicos e que, invariavelmente, foram permeadas por um projeto político de sustentação do Império Português nas duas margens do Atlântico. Os temas abordados perpassam desde a estruturação das novas instituições régias que surgiam na América Portuguesa e delineavam a nova governabilidade da monarquia portuguesa, com sede no Rio de Janeiro, a partir de 1808, à volta de Dom João VI para Portugal, em 1821, quando as consequências da crise do Antigo Regime Português já apareciam de forma mais patente no universo público, ao fim do período, mais precisamente entre 1817 e 1821 . 
A CHEGADA DA FAMÍLIA REAL E AS MUDANÇAS SOCIOPOLÍTICAS

No dia 14 de janeiro de 1808, o brigue Voador trazia ao porto do Rio de Janeiro a notícia de que a Família Real estava a caminho do Brasil. Desde então, os ânimos da sociedade carioca fervilhavam. Três dias depois, em 17 de janeiro, o desembarque das sete naus portuguesas e dos três barcos ingleses no cais do porto despertava a imensa curiosidade da população que aguardava ansiosamente a chegada do Príncipe Regente e sua corte em terras americanas. Para desapontamento da maioria da casta real, entretanto, chegavam apenas as duas irmãs da rainha D. Maria I: d. Maria Benedita e D. Maria Ana, além das duas infantas, Maria Francisca de Assis e Isabel Maria.

Sem saber o que havia acontecido com os demais membros da dinastia de Bragança, as nobres senhoras e senhoritas da família real não aceitaram o convite do conde dos Arcos para aportarem em terra firme. Preferiram ficar a bordo dos navios à espera de notícias, que só chegariam ao Rio um mês depois. Enquanto isso, os demais tripulantes circulavam pela cidade em busca de acomodação.

Esse momento, ainda tão singelo perto do que viria a ser o dia 7 de março, já prenunciava as importantes transformações que ocorreriam na sociedade luso-brasileira. Novas etiquetas, rituais e solenidades começavam a ser vivenciados pelas ruas da sede da Colônia que, em 22 de fevereiro, ficava ciente de que a Família Real - juntamente com a nobre comitiva portuguesa - encontrava-se em Salvador e, tão logo fosse possível, estariam no Rio de Janeiro. A tônica das conversas girava em torno da chegada em carne e osso da Rainha, do Príncipe Regente, seus familiares e acompanhantes. Todos se preparavam para a pompa que enfeitaria a grande ocasião...

Enfim, em 7 de março, a esquadra real aportava no porto da baía de Guanabara. A cidade estava em festa e o espetáculo da chegada foi um momento único: as salvas de canhões, os tiros de fuzis e as badaladas dos sinos das igrejas anunciavam a entrada triunfal da família real que recebia as homenagens por toda a parte. D. Maria, dom João e Carlota Joaquina foram recepcionados pela elite política da cidade, composta, sobretudo, pelo Conde dos Arcos, os membros do Senado da Câmara, além de renomados eclesiásticos, civis e militares. Com olhares curiosos, o restante da população se amontoava pelas praias e morros assistindo atentamente ao entourage, que ganharia contornos mais efusivos no dia seguinte. Em suas memórias, 
o padre Luiz Gonçalves dos Santos, mais conhecido como padre Perereca, registrava sua emoção ao ver a entrada da realeza na América Portuguesa.

Rio de Janeiro, Cidade a mais ditosa do Novo Mundo! Rio de Janeiro, ai tens a tua Augusta Rainha e o teu excelso Príncipe com a sua Real Família, as Primeiras Majestades que o Hemisfério Austral viu e conheceu. Estes são os teus soberanos e senhores, Descendentes e Herdeiros daqueles Grandes Reis que te descobriram, te povoaram, te engrandeceram ao ponto de serem de hoje em diante Princesa de América e Corte dos Senhores Reis de Portugal; enche-te de júbilo, salta de prazer, orna-te dos teus mais ricos vestidos. Sai ao encontro dos teus Soberanos e recolhe com todo o respeito, veneração e amor o Príncipe ditoso, que vem em nome do Senhor visitar o seu Povo. (Santos, 1825: 16)

Apesar da chegada triunfal, os membros da realeza só desembarcariam efetivamente em solo carioca no dia seguinte, em 8 de março, por volta das quatro horas da tarde. Os júbilos de apreço popular pela presença das personalidades reais se faziam sentir nas diversas manifestações. Foguetes, salvas de artilharia e repiques de sinos em meio às chuvas de folhas e flores atenuavam temporariamente as angústias do príncipe regente por ter deixado o Reino invadido à mercê dos franceses.

Enquanto dom João se deixava inebriar pelas congratulações de boas vindas e pela belíssima geografia da Baia de Guanabara, D. Carlota Joaquina chorava convulsivamente: tinha seu orgulho ferido por ter que aceitar a condição - para ela degradante - de ser uma princesa e futura rainha de possessões coloniais.

O amor de dom João e o repúdio D. Carlota pelo Brasil foi uma diferença central nos olhares e sentimentos que cada um cultivou pelo país ao longo dos treze anos de permanência nos trópicos. Se essa percepção já se fazia presente logo nos instantes iniciais da chegada da corte, também foi no primeiro contato da realeza com seus súditos da Colônia que os rituais cortesões se manifestavam de modo a marcar a singularidade dos novos tempos e costumes. "Uma extensa parada militar tomava a praça e formava alas para a Rua do Rosário e Rua Direita até ao adro da Catedral. O cortejo progredia com lenta, imponente majestade", expõe Luiz Norton (1938: 52).

Já na Catedral, a missa que os recepcionava enchia de pompa a cidade. Com grande instrumental, os súditos mais ilustres cantavam entre outras músicas o hino de Graça, ao mesmo tempo em que suas altezas concediam um beija-mão geral, um ritual público da realeza que teve importância central nas relações sociopolíticas entre o soberano e seus súditos no período joanino. "Era uma cerimônia que punha o monarca em contato direto com o vassalo, que lhe apresentava as devidas vênias e suplicava por alguma mercê. 
Reforçava-se nele a autoridade paternal do soberano protetor da nação", relata Jurandir Malerba (2000: 184). Finda a recepção, a realeza seguia em coches próprios para o Palácio, sempre acompanhados da multidão curiosa para saber o que aconteceria dali em diante.

Se a beleza do cenário geográfico da cidade encantava a maioria da corte portuguesa que desembarcava no porto do Rio, os primeiros dias mostrariam a precariedade da estrutura da nova capital. "Numa pequena área espremida entre a praia e a montanha, formada por escassas ruas paralelas e mais algumas transversais, rodeadas por matas e logradouros desertos, mais de dez mil pessoas foram alojadas às pressas, com a chegada da Família Real, transformando a pequena cidade dos vice-reis em capital do império português na América", descreve a historiadora Leila Mezan Algranti (1988: 26).

Para acomodar os acompanhantes da corte, o conde dos Arcos instituiu o sistema de aposentadorias que, na prática, requisitava as casas dos moradores locais para aconchego da nobreza. Na porta de muitas casas foram pregadas as letras $P R$ - Príncipe Regente -, interpretadas pela população como Ponha-se na Rua. "O afluxo de uma grande quantidade de pessoas agravou os problemas urbanos. Além da falta de moradia, havia carência no abastecimento de água, saneamento, segurança pública", descreve o historiador Paulo de Assunção (2008: 88). Essa situação causou um enorme rebuliço tanto para a população que ficava desabrigada, quanto para a nobreza portuguesa que considerava as moradias desconfortáveis, mal construídas e sem o luxo das suas residências em Lisboa. Já a população mais pobre ficou marginalizada à região norte da cidade, circunscritas aos bairros de Catumbi e Mata-Porcos. Nesse espaço, as habitações se restringiam a choças aglomeradas entre os morros e o mar, o que já marcava a profunda desigualdade social no especo geográfico (Lima, 2000: 106).

Aos poucos, no entanto, as transformações urbanas foram modificando a estrutura da cidade. Para além das quatro freguesias já existentes - Sé, Santa Rita, São José e Candelária -, foi criada o Engenho Velho. Novas ruas foram pavimentas e as estradas alargadas. A iluminação, saneamento, abastecimento de água potável e, consequentemente, a higiene também foram aspectos que sofreram importantes melhorias na cidade. Ou seja, entre os anos de 1808 e 1822, a área do Rio de Janeiro havia triplicado. Mas como bem adverte a antropóloga Lilia Schwarcz, "Se a vila se modificou para se vestir como capital do império português, as permanências são evidentes. Suas casas e traçados coloniais, suas festas tomadas por costumes africanos, seus hábitos alimentares orientais... nada permite duvidar de um universo obrigatoriamente plural" (Schwarcz, 2008: 6). A pluralidade de universos 
se fez sentir nos mínimos detalhes. A rotina da vida no Rio de Janeiro se transformava por completo.

A começar pelo crescente número de habitantes entre os anos de 1808 e 1821. Se até 1808 o Rio de Janeiro era uma cidade com cerca de 60.000 habitantes, o censo de 1821 já apontava para uma população em torno de 79.321 pessoas, contando o alto número de estrangeiros que fixaram residência (em torno de 10.000 mil pessoas), escravos, libertos e população livre (Martins, 2008: 107).

Esse aumento populacional está intimamente relacionado às alterações socioeconômicas advindas da transferência da Família Real para o Brasil. Porém, se desde o final do século XVIII, a importância do Rio como centro importador de escravos já era notável, nos treze anos em que a Corte permaneceu no Brasil houve a predominância da capital no cenário internacional, sobretudo devido à abertura dos portos e o processo de transição de uma economia fechada e monopolista para uma economia aberta. O porto do Rio de Janeiro se tornava o principal centro econômico do país.

$\mathrm{O}$ crescimento da cidade provocou uma ampliação significativa na demanda de serviços urbanos, o que refletia diretamente na valorização do tráfico negreiro. "A crescente necessidade de mão de obra fazia com que os olhos se voltassem para a África. Após 1809, o volume de tráfico de escravos para o Rio de Janeiro aumentou sensivelmente", complementa Algranti (1888: 33). Por volta da década de 1820, a cidade chegou a ter 34 mil escravos por ano, uma estatística bem acima daquela vigente em 1809, que apontava uma entrada anual do número de negros na cidade entre $5.839 \mathrm{e}$ 10.536 (Klein, 1978: 54-55).

População total da cidade do Rio de Janeiro em 1808 e 1821

\begin{tabular}{|c|c|c|c|c|c|}
\hline Ano & Fogos & $\begin{array}{c}\text { População } \\
\text { Livre }\end{array}$ & Libertos & Escravos & Total \\
\hline 1808 & 4.000 & 47.090 & 1000 & 12.000 & 60.000 \\
\hline 1821 & 10.151 & 43.139 & -- & 36.182 & 79.321 \\
\hline
\end{tabular}

(Fontes: 1808: Luccock. Notas sobre o Rio de Janeiro e partes meridionais do Brasil. Belo Horizonte, 1975, p. 28. 1821. Censo de 1821. RIHGB, t.33, parte.1, 1870, p. 135-142)

A nova estrutura da cidade despertava os holofotes, senão do mundo, pelo menos dos europeus, ávidos por receberem as notícias da Corte portuguesa e conhecerem as transformações implementadas pelo Príncipe Regente dom João na nova capital do Império. Viajantes, cientistas, 
estrangeiros de toda parte chegavam ao Rio de Janeiro senão com o objetivo de fixar moradia, pelo menos de explorar as faces ainda desconhecidas da América Portuguesa. Tal foi a transformação que, em 9 de junho de 1811, foi publicado um edital da Intendência da polícia que já enunciava claramente a posição adquirida pela cidade como capital do Império Português, agora com sede nos trópicos.

(...) Havendo se elevado esta cidade a alta hierarquia de ser hoje Corte do Brasil (...) não pode nem deve continuar a conservar (...) antigos costumes que apenas podiam tolerar-se, quando era reputada com uma Colônia e que desde muito tempo não sofrem em povoações cultas e de perfeita civilização (...) testemunhos da antiga Condição de Conquista e Colônia, concorrendo para estabelecer a sua Corte e fazê-la mais notável aos olhos das Nações Estrangeiras. (ANRJ - CÓD.323, v.1. fl. 88-88v.)

Como bem explicitava Paulo Fernandes Viana, intendente da polícia, desde 1808 que os novos rituais ditos civilizados passaram a fazer parte do cotidiano da cidade. O calendário oficial imposto pela realeza colocava em cena datas comemorativas que se intercambiavam entre os dias santos da religião católica e os fatos políticos da monarquia. Celebrações religiosas, cortejos e aniversários reais, paradas militares. Enfim, uma ampla gama de solenidades públicas passou a ocorrer quase todo mês. Cada festejo, contudo, tinha uma finalidade específica. "Determinados eventos eram lembrados com uma missa cantada; outros eram assinalados pelo "beija-mão" no Paço e havia as grandes comemorações que articulavam uma série de eventos festivos, como as Aclamações reais", explica o historiador Emílio Lopes (2004: 30). Apesar das diferenças, todas as comemorações tinham como eixo a presença da Família Real, fosse de corpo presente ou por meio de retratos. "Era fundamental que os signos e sentidos da realeza circulassem pelo tecido social, fossem comunicados e, de alguma forma, apreendidos", elucida a historiadora Iara Lis C. Schiavinatto (1999: 53).

Durante as mais diversas festividades, era valorizada a fé dos indivíduos que vivenciavam nesses momentos formas diferenciadas de aprofundamento do espaço destinado à interlocução social e ao debate político. Nas comemorações que exteriorizavam as práticas monárquicas, os projetos políticos da realeza se faziam notar com mais intensidade: a aura paternal e amorosa do Rei para com os seus súditos era exaltada, numa clara tentativa de minimizar as faces da crise vigente no Antigo Regime Português. "A cidade era o local onde se desenrolavam as grandes cenas da vida cotidiana de seus habitantes, mas também era o espaço de representação do poder", afirma Paulo de Assunção (2008: 96). 


\section{A reestruturação administrativa da Corte}

Desde 1808, as medidas reais já apontavam para uma mudança de cenário na Corte. A manutenção e o bom funcionamento da burocracia estatal da monarquia portuguesa deste lado do Atlântico pressupunham a transladação de importantes instituições régias cuja lógica, segundo a historiadora Leila Algranti, "inseria-se na antiga política colonial de fortalecer no Brasil um Estado extremamente dependente, vinculado às organizações de Lisboa, sem autonomia ou criatividades próprias" (1988: 35). Apesar disso, as instituições régias aqui instituídas alterariam significativamente a prática das decisões políticas no Império Português e também a vida cotidiana da cidade.

A Intendência-Geral de Polícia da Corte, uma das principais instituições que garantiam a segurança pública, foi criada em 5 de abril de 1808. Com amplos poderes, o desembargador carioca Paulo Fernandes Viana assumiu o cargo de intendente, ocupando-o até fevereiro de 1821. Responsável pela guarda pessoal da família real, também tinha como atribuições fiscalizar a construção dos teatros, manter a "ordem" das festas públicas, deter escravos fugidos, prender pessoas "perigosas" ao governo, vigiar a cidade para que não houvesse badernas ou crimes, registrar a entrada e saída de estrangeiros, assim como cuidar da reestruturação da cidade, que crescia e se transformava a olhos vistos.

Houve momentos, no entanto, que a sua autoridade foi publicamente contestada. Em 1811, ao prender pessoas consideradas inocentes pelo Príncipe Regente, Viana recebeu um comunicado na seção noticiosa da Gazeta do Rio de Janeiro que ordenava a soltura dos presos. ${ }^{1} \mathrm{O}$ aviso foi assinado por D. Rodrigo de Souza Coutinho, Conde de Linhares, ninguém menos que o ministro de maior proeminência no governo até 1812.

Com a transladação da Família Real para o Brasil, D. Rodrigo ficou responsável pelo Ministério dos Negócios Estrangeiros e da Guerra, órgão de suma importância política na estruturação administrativa do Império deste lado do Atlântico. Entre os anos de 1808 e 1812, o ministro foi febril na tentativa de implantação de atividades reformadoras a fim de consolidar o seu projeto político de um novo império, que fosse capaz de evitar as explosões revolucionárias no Brasil. Ao defender tenazmente a aliança com

\footnotetext{
1 Para uma análise mais detalhada sobre a Gazeta do Rio de Janeiro ver: MEIRELLES, Juliana Gesuelli, Imprensa e poder na corte joanina: A Gazeta do Rio de Janeiro. Ed. Arquivo Nacional: Rio de Janeiro, 2008; CARDOSO, Tereza Maria Rolo Fachada Levy. A Gazeta do Rio de janeiro: subsídios para uma história da cidade (1808-1821), Dissertação de Mestrado, UFRJ, RJ, 1988 e SILVA, Maria Beatriz Nizza da, Gazeta do Rio de Janeiro (1808-1822): Cultura e Sociedade: Rio de Janeiro: Eduerj, 2007.
} 
os ingleses, acreditava primar pela alta consideração de Portugal entre as nações europeias o que, para ele, garantiria também a unidade do vasto império colonial, já abalada pelos ventos das novas ideias revolucionárias. "Construir uma unidade nacional luso-brasileira era a ideia central da nova política proposta pelo ministro, demonstrando o quanto o governo ilustrado estava atento às questões cruciais daquele momento vivido", explicita a historiadora Maria de Lourdes Viana Lyra (1994: 72).

Sua morte súbita, em janeiro de 1812, gerou uma onda de boatos pela cidade do Rio de Janeiro. Ainda segundo Lyra, esta situação bem demonstrava "o clima de tensão gerada entre os distintos grupos envolvidos diretamente no processo de implementação do projeto de um novo império lusitano com sede no Brasil" (Lyra, 1994: 145), cujas divergências políticas giravam em torno da defesa de ideais antagônicos: os interesses nacionais, entre portugueses que defendiam os interesses do Reino e a parte de um grupo ilustrado, que defendia a preeminência do Brasil no cenário nacional. Tal foi a importância de D. Rodrigo que, em 29 de janeiro de 1812, era publicada uma pequena biografia do ministro nas páginas da gazeta oficial. A retórica laudatória do redator o considerava uma das figuras mais importantes do governo, "um dos mais firmes esteios da monarquia portuguesa" que muito contribuíra para "o aumento e prosperidade da Nação". 
Aviso so Jutendense Geral dis Policia.

Havenda subido à Augusta Presença de S. A. R, - Priscipe Regente Nosso Sexhon a Conta, e Processos Inquisitorios, que V.S. me remettêo em dita de 27 de Setembro, das Pessoass que fôtạa acçcusadas, como suspeitas, e vendo S. A. R. que a accusaçáo náo procede, , antes sq mostra pelos exames 2 que se procedeo, que rodas as Pessons accusadas e detidas náo só estéo innocentes, mas derio em toda a parte decididas provas da spa fidelidade e amor para o seu Soberano, o Melhor dos Principes: He - Mesmo Augusto Senhor Servido que V. S. náo só mande pôr .em libendade os que estáo aqui detidos, mas que, tambem mande praticat o mesmo com hum dos Navarros, que ficou ainda na Babia, e thes déchaie, que $S_{i} A . R$. ficou inteiramente convencido da sua innocencia ; e que ao Pio e Virtuoso Coraḉo de hum táo Benigno Soberano, foi bem doloroso, que, a necessidade, as criticas circumstuncias imperiosas do mopento, e puma denuncia, que parecia fundada, thes exusassem huma desagradavel detençáo, de que com tudo thes náo deve resuitar maior ineommodo, logo que fica justificada a sua innocencia, e restitcuidos a Graça do seu Soberano. O mesmo Ordena S. A.R., que V.S. pratique a respeito do Fespanbol Harrecbe, pondo-o em inteira liberdade, dendo-lhe Passaporte para poder seguir a sua viagem para a Babia e Havanna, depois de se the rescituir tudo o que the foi aprehendido.

\section{Deos guarde a V.S. Palacio do Rio de fanciro} em 28 de Setembro de 1811 .

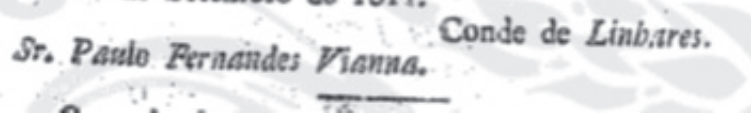

(Fonte: Gazeta do Rio de Janeiro, 9 de Novembro de 1811, n.81, p.2)

Apesar das controvérsias políticas no âmbito imperial, a preponderância do intendente da polícia - no aspecto local - fazia-se presente em múltiplos aspectos no governo joanino: das diversas ocorrências da vida cotidiana às decisões referentes à política imigratória, Viana mantinha um canal de comunicação direta com D. João, que o encontrava três vezes por semana a fim de ter ciência de tudo o que se passava na cidade. A maioria das pessoas o considerava uma autoridade terrível, já que a sua figura repressora tinha o aval e a confiança do monarca. ${ }^{2}$ Ao deixar o cargo de intendente em 1821,

2 BNRJ. MORÃES, Alexandre José de Melo, Dados sobre a chegada ao Rio de Janeiro 
Viana se vangloriava de seus feitos, ressaltando os benefícios que trouxera para o processo de urbanização do Rio.

"Aterrei imensos pântanos da cidade com que se tornou mais sadia (...), fiz calçada na rua do Sabão e de S. Pedro, na Cidade Nova: na R. dos Inválidos (...) fiz o cais do Valongo (...) Por não haver na cidade abundância d’água para o uso público consegui (...) conduzir água até para beber em uma légua de distância... 'criei' e fui sempre aumentando a iluminação da cidade" (Viana, 1892: 374-375.)

Um mês depois da criação da Intendência da Polícia - que marcava sua centralidade dentre as instituições diretamente relacionadas à vida cotidiana -, dom João implantava a primeira tipografia na Colônia, denominada de Impressão Régia. O decreto que oficializava a publicação de papéis públicos e particulares, em 13 de maio de 1808, era produzido nos moldes retóricos do Antigo Regime português:

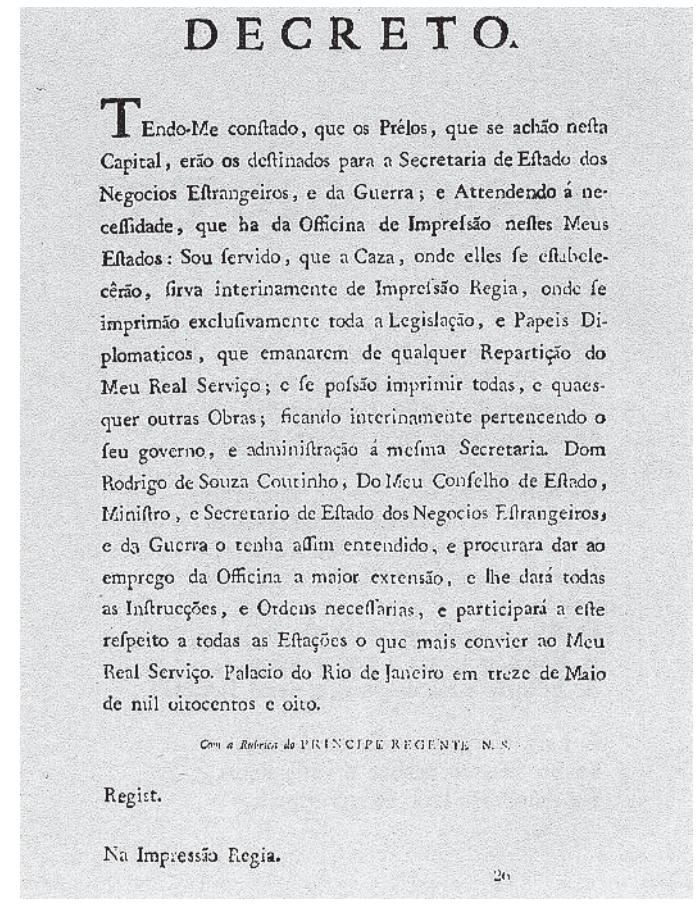

da Família Real, problemas de habitação para a comitiva, vida social e política, hábitos da familia real, volta para Portugal, falecimento de D, João VI e Pedro I como imperador, S.l, s.d, Original (transcrição feita por Cecília Coelho, maio de 2001). Divisão de Manuscritos, II-30, 23, 6,7. 
A data que institucionalizava o nascimento da palavra impressa no Brasil não foi, de forma alguma, uma escolha aleatória; ao contrário, o decreto era publicado exatamente no dia do aniversário de dom João, um dia muito significativo no calendário da realeza. Marcar as medidas estatais nas datas natalícias da família real também fazia parte da política absolutista, pois o "controle do tempo era fundamental para perpetuar uma memória das ações do Rei e dar legitimidade ao seu poder", afirma o historiador Emílio Lopes (2004: 89).

Em 24 de junho de 1808, pouco mais de um mês depois da publicação do decreto real de 13 de maio, era divulgado um regimento que delimitava ainda mais as funções da junta administrativa da Impressão Régia e do intendente da polícia Paulo Fernandes Viana diante da produção e circulação de papéis públicos e privados. Dizia o documento que competia aos diretores da tipografia "examinar os papéis e livros que se mandassem publicar e fiscalizar para que nada se imprimisse contra a religião, a moral e os bons costumes", tendo o intendente da polícia total autorização para prender aqueles que transgredissem a "segurança pública", ao veicularem escritos impressos ou manuscritos que fossem considerados sediciosos pelos censores da realeza, sobretudo aqueles cujas ideias fossem contrárias ao governo. Quem ousasse ultrapassar esse limite estava sujeito a pagar uma multa de duzentos mil réis, que poderia ser cobrada mesmo que o acusado não estivesse ciente da acusação, já que a polícia admitia e incentivava denúncias em segredo.

Peça-chave no processo de comunicação interatlântica, intimamente associado à veiculação da propaganda do Estado e, consequentemente, à sustentação do Império Português nos dois lados do Atlântico, a Impressão Regia tinha numerosas funções que extrapolavam a impressão exclusiva de todos os papéis ministeriais e diplomáticos do serviço real de todas as repartições. Ficava sob a sua responsabilidade também imprimir as obras de particulares, tanto quanto produzir e fazer circular a Gazeta do Rio de Janeiro. ${ }^{3}$ Mesmo sob constante atuação da censura, como editora a Impressão Régia publicou até 1822 muitos livros de amplo valor cultural. Nesse período, foram impressos 720 títulos que versavam sobre diversas temáticas: opúsculos, sermões, prospectos, obras literárias e científicas

3 Sobre a importância da Gazeta do Rio de Janeiro, ver: CAMARGO, Ana Maria de Almeida e MORAES, Rubens Borba de, Bibliografia da Impressão Régia do Rio de Janeiro, Edusp, São Paulo, 1993. MEIRELLES, Juliana Gesuelli, Imprensa e poder na corte joanina: A Gazeta do Rio de Janeiro.Ed. Arquivo Nacional: Rio de Janeiro, 2008. CARDOSO, Tereza Maria Rolo Fachada Levy, A Gazeta do Rio de janeiro: subsidios para uma história da cidade (1808-1821), Dissertação de Mestrado, UFRJ, RJ, 1988 e SILVA, Maria Beatriz Nizza da, Gazeta do Rio de Janeiro (1808-1822): Cultura e Sociedade: Rio de Janeiro: Eduerj, 2007. 
sobre matemática, história, ciência política, economia e filosofia, teatro, romances, dramas, entre outros. Já em relação à documentação oficial, no mesmo período foram contabilizadas 1.427 publicações (Schwarcz, 2002: 251).

Os censores régios eram personagens importantes nesse processo de comunicação que cotidianamente delineava a nova sociabilidade da Corte. Escolhidos a dedo entre os membros da elite, foram nomeados 13 homens da órbita seleta da família real. Entre os anos de 1808 e 1819, sete exerciam o sacerdócio, quase todos tendo alcançado posição de destaque. Quanto aos leigos, todos eram formados pela Universidade de Coimbra. Dentre eles, um era membro dos Reais Exércitos; dois eram médicos; e três, advogados. Posteriormente, alcançaram títulos de nobreza ou, pelo menos, mercês de ordens militares (Silva, 1994: 158). Na dinâmica da vida social, ao ocuparem cargos públicos cuja função era, antes de tudo, fiscalizar o bom andamento da "ordem", esses leais servidores da monarquia conquistavam status e prestígio, valores que dignificavam os indivíduos em uma sociedade de corte concebida pela ótica do Estado absolutista, na qual todos eram naturalmente desiguais perante a lei. As obras de responsabilidade desses homens eram encaminhadas para a Mesa do Desembargo do Paço - organismo censor no Brasil responsável por expedir todas as licenças de circulação/proibição das obras literárias que chegavam à alfândega -, a fim de que eles analisassem o conteúdo considerado pertinente ou não à leitura em sociedade.

Essa atividade, contudo, era altamente complexa. A liberação de uma obra nem sempre transcorria de forma cristalina, sendo a "ausência de procedimentos isentos e de normas claras, tanto dos que exerciam a censura, quanto dos interessados na liberação das listas" um fator intrínseco à prática da censura (Algranti, 2004: 140). Os censores tinham em suas mãos uma enorme gama de títulos e autores, o que tornava praticamente impossível o conhecimento do conteúdo de todas as obras. Nesse sentido, esses homens ilustrados exerciam a censura baseados mais em seus saberes particulares e em consonância com os valores políticos e religiosos da época do que em critérios previamente definidos. "Assim, a falta de critérios claros, a dificuldade de acesso aos róis de livros proibidos e as listas mal elaboradas desencadeavam não apenas dúvidas, mas também desavenças e disputas entre os homens de confiança do monarca", elucida Leila Algranti (2004: 144).

Com o advento da tipografia na Colônia, portanto, há uma crescente variedade de gêneros e títulos, inclusive com um aumento significativo do interesse dos leitores pelas ideias dos filósofos iluministas, como Voltaire, Rousseau e Montesquieu. Apesar da curiosidade, as obras mais famosas eram consideradas "sediciosas" pelos censores de dom João que vedavam constantemente a sua circulação. "O Sistema da Natureza, de Holbach, best seller entre as obras proibidas na França nessa época, parece também 
ter sido desejado pelos leitores da Colônia, pois os livreiros estrangeiros e portugueses tentavam introduzi-lo com frequência no país" (Algranti, 2004: 149). Inserido nesse complexo movimento, há o florescimento do romance como gênero literário, fato que contribuiu tanto para a mudança de sensibilidade dos leitores como para uma estruturação do mercado editorial no Brasil, nas primeiras décadas do século XIX.

Se, por um lado, os censores tinham especial atenção na entrada dos livros proibidos, a exemplo das obras francesas, com destaque para Émile, de Rousseau, Historie philosophique, do abade Raynal e Os direitos do Cidadão, de Mably, por outro também escolhiam e incentivavam a produção de livros muito procurados ou populares à época, como os 23 volumes de $A$ sagrada Bíblia, traduzida em português pelo padre Antonio Pereira, ao preço de 28 mil réis, vendida na loja de Paulo Martin Filho (Gazeta do Rio de Janeiro, $1810, \mathrm{~N}^{\circ} 71$ ), a nova edição em prosa da Carta de Heloísa á Abelardo; vendida por 320 réis nas lojas de Manoel Joaquim da Silva Porto e na Gazeta (Gazeta do Rio de Janeiro, 1812, N 97 ) e também o Índice da $1^{\mathrm{a}}$ parte das Preleções Filosóficas, de Silvestre Pinheiro Ferreira, dispostas em ordem alfabética, vendido nas lojas de livros de Francisco Luis Saturnino, onde podiam ser facilmente comprados nas casas livreiras da cidade (Gazeta do Rio de Janeiro, 1818, $\mathrm{N}^{\circ} 65$ ).

Com o passar do tempo, o anúncio das obras que saíam a público na cidade se tornou parte da política editorial dos diretores da Gazeta do Rio de Janeiro, que os inseriam na seção denominada Avisos. Da mesma forma que os editores utilizavam esse espaço para divulgar os livros produzidos pela tipografia real, também a sociedade fez desse espaço um locus ativo de interação social. Ao anunciarem seus interesses particulares na Gazeta do Rio de Janeiro a partir de narrações ou relatos do cotidiano, as pessoas transmitiam suas impressões coletivas no jornal de modo a conquistarem suas vozes que, pouco a pouco, tornavam-se públicas.

Desde 1809, a educação foi um tema de destaque na sociedade joanina: na seção de Avisos da Gazeta, muitas pessoas ofereciam seus préstimos educacionais. Das aulas particulares de alfabetização ao conhecimento da gramática das línguas portuguesa, francesa, inglesa, latina, perpassando a fundação de colégios exclusivos para moços ou meninas, vemos o quanto a preocupação com o enriquecimento cultural se tornava presente no cotidiano dessa sociedade, agora imersa nas mudanças culturais ocorridas na Corte.

Em 1811, o professor de primeiras letras Jordão Reinaldo, chegado como sua família de Lisboa, convidava as pessoas a fazer parte de suas aulas que, segundo ele, ensinariam "tudo o que é preciso para ser um bom hábil negociante e um útil cidadão". As aulas aconteceriam na rua dos pescadores, na casa do coronel Manoel Caetano Pinto (Gazeta do Rio de Janeiro, 1811, 
$\mathrm{N}^{\circ}$ 62). Ainda em 1811, um senhor de nome Lírio fundava um colégio de educação pública, no Catete, "onde solidamente se ensinam todas (sic) as ciências com o método mais fácil [e] novo". O local propunha-se a ensinar em pouco tempo as "melhores conveniências para a instrução de qualquer menino bem nascido", que teria a sua disposição um extenso plano acerca da solidez da casa, sob a direção de um reitor (Gazeta do Rio de Janeiro, $1816, \mathrm{~N}^{\circ} 89$ ).

A prática da escrita e leitura também fez parte dos interesses da população. Escrever com maior agilidade por meio do aprendizado da "Stenographia Portuguesa (sic), ou arte de escrever com a rapidez da palavra", foi um serviço que certamente despertou interesse de muita gente. Segundo o professor, tal prática era uma convenção adotada em todos os idiomas e que poderia trazer muitas vantagens para a interiorização da língua e gramática (Gazeta do Rio de Janeiro, 1817, $\mathrm{N}^{\circ} 50$ ). Outro aviso inusitado foi a venda de uma livraria especializada em obras jurídicas, consideradas pelo anunciante próprias e muito úteis para qualquer advogado ou magistrado (Gazeta do Rio de Janeiro, 1809, N 99).

Os constantes anúncios literários e as vendas de livros, folhetos e impressos publicados na Gazeta do Rio de Janeiro nos revelam as possíveis preferências do público leitor/consumidor da época que estava em consonância com a tradição literária herdada desde finais do século XVIII, como as belas letras, teologia, ciências e arte, história e jurisprudência.

O enraizamento do hábito da leitura, assim como as novas formas de educação nascentes, seja em âmbito público ou privado, marcam o significativo processo de transição cultural pela qual passava a sociedade joanina no início do Oitocentos. Nessa passagem, pode-se verificar o hibridismo nas formas de leitura que mesclavam as características predominantes no Antigo Regime - como as exposições de cartazes impressos ou manuscritos nas ruas e as leituras coletivas feitas geralmente em voz alta - e a formação de um novo espaço público, cujo centro será a imprensa compreendida como uma arena de debates já intimamente associada a uma prática de leitura individual feita em ambientes privados. Essa mudança é tão expressiva que, ao final do período joanino, a sociedade já manifestava suas potencialidades de leitura crítica da realidade também na esfera política.

\section{INSTITUIÇÕES REAIS E SOCIABILIDADE NA COLÔNIA}

A força dessas transformações estava vinculada também à reestruturação do espaço público imposto pela monarquia portuguesa por meio da criação de estabelecimentos régios de caráter eminentemente político e cultural. Em 
1808, foram criados o Jardim Botânico, a Academia Real da Marinha e a Impressão Régia, juntamente com os demais setores político-administrativos importantes referentes à atuação do Estado, como a polícia, a justiça, a fazenda e a área militar (Schwarcz, 2002: 247). A Casa de Suplicação, o Desembargo do Paço e a Mesa de Consciência e Ordens também foram instituições judiciais que se sobrepuseram à antiga estrutura colonial, atos que marcavam a centralidade do Rio de Janeiro como a nova capital do Império Português.

A criação do Jardim de Aclimatação (futuro Jardim Botânico), em 13 de junho de 1808 , foi um momento sui generis na constituição de um espaço público voltado para o cultivo das ciências naturais. Destinado ao cultivo de plantas exóticas, esse jardim ficou sob a responsabilidade de João Gomes da Silveira Mendonça. A partir de então foram feitos estudos para determinar as propriedades úteis das numerosas plantas que adentravam ao território. O intuito era a aplicação prática desses novos cultivos, culturas e plantações que criaram raízes na cultura brasileira pela iniciativa do Príncipe Regente. Com o interesse de multiplicar o alcance do comércio pela fabricação de substâncias úteis, introduziu-se no Rio árvores de especiarias como canela, cravo, pimenta, noz-moscada, além do plantio de chá que, vindo diretamente da China, teve cuidados especiais do monarca.

Em 13 de julho de 1811, o redator da Corte fazia um comentário muito curioso na seção Rio de Janeiro, a parte opinativa da folha. O tema contemplado foi a chegada de plantas exóticas e medicinais no Brasil, vindas da cidade de Caiena, na Guiana Francesa. Dizia o escrito que as novas plantas podiam ser cultivadas pelos lavradores que se interessassem em plantar novos gêneros, considerados muito úteis para o aumento das riquezas do Brasil. O curioso dessa passagem é que o redator não perdeu a oportunidade para utilizar o espaço com o intuito de "informar" os leitores do periódico sobre a situação política da região de Caiena, que já não mais estava sob as rédeas do "monstro" Bonaparte, assim como exaltava as atitudes "paternais" de D. João. 
Rio de Zanelio 83 de Z̈rlbo.

Com muito prazer fazernos corhecer ao Público, que pela Escuna que veio ie Cayenna, denominada Princeza D. Maria Teres $a$, , remettea o Intendente Geral daquella Coloniz, o Desemb.r jador Fo.io Severiano Maciel da Cos:a; segundo as Re.tes Ordens que havia recebido, muicas plantas de especiarias, quaes o Giroflier, ou cravo da India, e o Muscadicr, ou Noz Muscada, com muitas outras pinntas exoticas, medicinaus, e de uso, quaes a $\mathrm{Ja}$ lapa, e Arvore do Păo, a Barbedine, \&cc., pa$\mathrm{ra}$ se introduzirem no Brazil , havendo já ficado muitas das mesmas plantas em Pernambuco, onde tocuu a Escuna, e chryado aqui as outras que trouxe hum habi cuitivador de Cayenna, $M$. Germain, e que por Ordem de S. A.R. váo ser plantadas no Jardim da Lagaa de Freitas para serem dali distribuidas pelos Lavradores, que quizerem cultivar táo interessantes plantas. Estas uteis culturas, que muito podem augmientar as producçóes, e a riqueza do Brazil, sáo novos beneficios que este Imperio recebe das benignas, luminosas, e pias Mảos do seu Suberano, que náo descança hum só momento de proniovèr a felicidade dos seus Povos, e que deixara impresso no coraçáo de todos elles hum momento eterno da sua beneticencia, ja que nảo ha dia que náo seja assignalario por novos bens, procurados a favôr cos seuś Vassallos, e de quem a posteridade dirá, como de outro Tito, que viveo para numerar os seus dias pelos das graças com que felicitou os seus Povos; do que o Brazil he o mais evidente testemunho; pois no breve espaço de poucos annos, vê lançados os mais solidos fundamentos da sua futura felicidade.

Por esta occasiấo se recebècio noticias seguras de que Cayenna florecia debaixo do paternal foverno de S. A. R., e se lembrava com gosto que jả náa pertencia ao monstro Bonaparte, usurpador do Throno Francez, e que ranto opprime os que rege cont inandita tyrannia. O habil, zeloso, e fiel Intenden: te Geral tem completamente desempenhado as paternaes, e luminosas Ordens de que S. A. R. foi sero vido encarrega-lo, e se tem feito bem merecedor das graças que S. A. R. náo céssa de derramar sobre os seus fiéis servidores.

Con?

(Gazeta do Rio de Janeiro, 13 de julho de 1811, N. 56)

Entre 1808 e 1815, os anos das guerras napoleônicas, a Coroa praticou uma política baseada em um rígido controle sobre a entrada de estrangeiros, sobretudo de origem francesa e espanhola. Diante dessa conjuntura, a atenção 
e atuação dos censores estavam voltadas para proibir a circulação de obras de origem francesa, consideradas "sediciosas", razão que muito estimulou a Imprensa Régia a publicar numerosos livros, folhetos e panfletos políticos de caráter antinapoleônico, como o Manifesto da razão contra as usurpações francesas, publicado em 1809, Memórias em que se examina qual seria o Estado de Portugal se por desgraça os franceses o chegassem a dominar, A verdadeira vida de Bonaparte, ambos de 1810.

Além disso, os diretores da Gazeta praticaram um nítido processo de edição das notícias francesas, cuja linha editorial não só exaltava a figura de Napoleão como o Anticristo, como também ressaltava publicamente as desconfianças das informações editadas em periódicos franceses, como aconteceu em dezembro de 1813, ainda em meio aos conturbados ventos da guerra peninsular. Ao anunciar as notícias da guerra pela ótica francesa, o redator comentava com seus leitores:

(...) daremos alguns extratos dos jornais de França bem próprios para mais e mais nos convencermos do pouco, ou nenhum crédito que merecem as notícias que nos vem por tão má parte. Como é possível faltar a verdade com tanto descaramento? Persuadir-se-ão por ventura aqueles noveleiros, que ainda podem atormentar a Europa com fantásticos e pomposos contos? Felizmente para ela, já lá vai o lamentável tempo de prestígios! (Gazeta do Rio de Janeiro, 1813, N. 98)

Já a partir de 1815, com o fim do apogeu napoleônico, Portugal e França reatavam as relações comercias. Há então uma visível mudança de enfoque em relação tanto às notícias de origem francesa veiculadas na folha oficial quanto à política cultural da Coroa no universo luso-brasileiro (Meirelles, 2008: 130-132). A vinda da Missão Francesa para o Brasil, por exemplo, representava os aspectos "louváveis ou desejáveis" dos valores que a civilização francesa representava de positivo nas relações entre os povos europeus. Pouco depois da chegada da Missão Artística, em meados de 1816, o governo criou a Escola Real de Ciências, Artes e Ofícios, um projeto que, apesar de não ter se consolidado, estava em consonância com a nova política cultural da Coroa. ${ }^{4}$ Dois anos depois, em 1818, era fundado o Museu Real que, sob a direção do Frei José Batista da Costa Azevedo, franciscano e professor de botânica e zoologia da Academia Real Militar, tinha como objetivo estimular os estudos de botânica e zoologia no local. Mesmo não possuindo um rico acervo, dom João in persona doou uma coleção particular "composta de

4 Atualmente há uma discussão importante na historiografia se realmente houve um projeto cultural acerca da vinda da Missão Francesa para o Brasil. Maiores informações ver Schwarcz (2008). 
peças de arte, gravuras, objetos de mineralogia, artefatos indígenas, animais empalhados e produtos naturais" (Schwarcz, 2002: 256-257). O Museu também foi concebido como um local onde a memória da nobreza portuguesa se perpetuaria ao longo das gerações (Malerba, 2000: 165).

Quanto ao cuidado das finanças, a preocupação também foi visível. A fundação do Banco do Brasil, em 1808, sinalizava o nascimento de novos tempos: a força de um banco nacional dava à Colônia um novo status político e econômico não só dentro dos limites imperais da monarquia portuguesa, mas também diante dos comerciantes internacionais, especialmente europeus e norte-americanos. Desde o alvará de 28 de janeiro de 1808 , que decretava a abertura dos portos às nações amigas, o Brasil vivenciava na prática uma nova realidade: a decisão rompia definitivamente com o Pacto Colonial ou Exclusivismo Metropolitano, já que a lei permitia a importação de gêneros e mercadorias estrangeiros, sobretudo das potências que mantinham boas relações com a Coroa Portuguesa, notadamente a Inglaterra.

\section{Criação do Banco do Brasil.}

\section{Alvará do Príncipe Dom João (12 out. 1808)}

Eu, o Príncipe Regente,

Faço saber aos que este meu Alvará com força de lei virem que, atendendo a não permitirem as atuais circunstâncias do Estado, que o meu Real Erário possa realizar os fundos de que depende a manutenção da Monarquia, e o bem comum dos meus fiéis vassalos, sem as delongas que as diferentes partes, em que se acham, fazem necessárias para a sua efetiva entrada: a que os bilhetes dos direitos das Alfândegas tendo certos prazos nos seus pagamentos, ainda que sejam de um crédito estabelecido, não são próprios para o pagamento de soldos, ordenados, juros e pensões, que constituem os alimentos do corpo político do Estado, os quais devem ser pagos nos seus vencimentos em moeda corrente; e a que os obstáculos, que a falta de giro dos signos representativos dos valores põem ao comércio, devem quanto antes ser removidos, animando e promovendo as transações mercantis dos negociantes desta e das mais praças dos meus domínios, e senhorio, com as estrangeiras: sou servido ordenar que nesta Capital se estabeleça um banco público que, na forma dos estatutos que com este baixam, assinados por Dom Fernando José, de Portugal, do meu Conselho de Estado, Ministro Assistente ao Despacho do Gabinete, Presidente do Real Erário e Secretário de Estado dos Negócios do Brasil, ponham em ação os cômputos estagnados assim em gêneros comerciais, como em espécies cunhadas; promova a indústria nacional pelo giro e combinação dos capitais 
isolados, e facilite juntamente os meios e os recursos de que as minhas rendas reais e as públicas necessitarem para ocorrer as despesas do Estado.

E querendo auxiliar um estabelecimento tão útil e necessário ao bem comum e particular dos povos, que o Onipotente confiou ao meu zelo e paternal cuidado: determino que os saques dos fundos do meu Real Erário, e as vendas dos gêneros privativos dos contratos, e administrações da minha real fazenda, como são os diamantes, pau Brasil, o marfim e urzela (sic), se façam pela intervenção do referido Banco Nacional, vencendo sobre o seu líquido produto a comissão de dois por cento, além do prêmio do rebate dos escritos da Alfândega que em virtude do meu real Decreto de 5 de setembro do corrente ano fui servido mandar praticar pelo Erário Régio, para ocorrer ao efetivo pagamento das despesas de trato sucessivo da minha Coroa, que devem ser feitas com espécies metálicas.

$\mathrm{E}$ atendendo à utilidade, que provém ao Estado, e ao comércio do manejo seguro dos cabedais e fundos do referido Banco; ordeno que, logo que ele principiar as suas operações, se haja por extinto o cofre de depósito que havia nesta cidade a cargo da Câmara dela, e determino que no sobredito Banco se faça todo e qualquer depósito judicial ou extrajudicial de prata, ouro, jóias e dinheiro; e que o competente conhecimento de Receita passado pelo Secretário da Junta do Banco, e assinado pelo Administrador da competente Caixa, tenha em juízo e fora dele todo o valor e crédito de efetivo e real depósito, para se seguirem os termos que por minhas leis se não devem praticar sem aquela cláusula, solenidade ou certeza; recebendo o sobredito Banco o mesmo prêmio que no referido Depósito da Cidade se descontava às partes. E outrossim sou servido mandar que os empréstimos a juros da lei, que pelo Cofre dos órfãos e Administrações de Ordens Terceiras, e Irmandades se faziam até agora a pessoas particulares da publicação deste Alvará, agora em diante se façam unicamente ao referido Banco, que deverá pagar à vista nos prazos convencionados os capitais, e nas épocas costumadas os juros competentes, debaixo da hipoteca dos fundos da sua caixa de reserva; distratando (sic) desde logo aqueles cofres as somas que tiverem em mãos particulares ao referido juro para entrarem imediatamente com elas no sobredito Banco Público debaixo das mesmas condições.

Em todos os pagamentos, que se fizerem à minha Real Fazenda, ser o contemplado, e recebidos como dinheiro os bilhetes do dito Banco Público pagáveis ao portador ou mostrador à vista; e da mesma forma se distribuirão pelo Erário Régio nos pagamentos das Despesas do Estado. 
E este se cumprirá como nele se contém. Pelo que mando à Mesa do Desembargo do Paço, e da Consciência e Ordens, o Presidente do meu Real Erário e Conselho de Fazenda; Regedor da Casa da Suplicação do Brasil, Governador da Relação da Bahia, Governadores e Capitães-Generais e mais Governadores do Brasil e dos meus domínios ultramarinos, e a todos os Ministros de Justiça e mais pessoas a quem pertencer o conhecimento e execução deste Alvará, que o cumpram e guardem, e façam inteiramente cumprir e guardar como nele se contém, não obstante quaisquer leis, alvarás, regimentos, decretos ou ordens em contrário, porque todos e todas hei por derrogados para este efeito somente, como se deles fizesse expresso e individual menção; ficando aliás sempre em seu vigor. E este valerá como carta passada pela Chancelaria, ainda que por ela não há de passar, e que o seu efeito haja de durar mais de um ano, sem embargo da ordenação em contrário; registrando-se em todos os lugares, onde se costumam registrar semelhantes Alvarás.

Dado no Palácio do Rio de Janeiro, 12 de outubro de 1808.

Príncipe

D. Fernando José, de Portugal

Alvará com força de lei, pelo qual Vossa Alteza Real há por bem criar um Banco Nacional nesta Capital, para animar o comércio; promovendo os interesses reais e públicos, na forma que nele se declara.

Para Vossa Alteza Real ver.

João Álvares de Miranda Varejão o fez.

Registrado nesta Secretaria de Estado dos Negócios do Brasil no Livro 1, de Decretos, Leis, Alvarás e Cartas Régias sobre Fazenda a fol. 28. Rio de Janeiro, 14 de outubro de 1808 .

Em 1810, foi criada a câmara de registros das Mercês e a Corporação de Armas, dois espaços que organizavam eficazmente o nascimento de uma classe nobre deste lado do Atlântico. "A concessão de graças honoríficas, como os títulos e os lugares das ordens militares e religiosas foi fartamente utilizada pelos monarcas como capital simbólico fundamental para retribuir a fidelidade de seus vassalos", explica o historiador Jurandir Malerba (2000: 212).

Os laços que aproximavam os súditos do Rei também eram cotidianamente reforçados durante o Beija-mão. $\mathrm{O}$ ato de beijar a mão do monarca era repleto de significados políticos intrinsecamente associados à lógica do Antigo Regime Português. Todos os dias, por volta das oito horas 
da noite (exceto aos domingos e feriados), dom João recebia seus súditos em uma sala especial no palácio de São Cristóvão, sua residência oficial.

O palácio de São Cristóvão, da Quinta da Boa Vista, foi uma doação de Elias Antonio Lopes, um dos mais ricos negociantes do Rio. A alta consideração desse vassalo para com a monarquia foi recompensada por dom João, que gratificou a sua generosa oferta com a sua nomeação como comendador da Ordem de Cristo, Fidalgo da casa real e administrador da mesma Quinta. ${ }^{5}$ As "subscrições voluntárias" dos vassalos portugueses e fluminenses também foram uma forma muito eficaz do Estado português arrecadar grandes fortunas para a sustentação dos cofres públicos. Geralmente, a generosidade desses súditos fiéis da Coroa tinha uma meta muito bem traçada: conquistar as graças de dom João, um status muito caro a uma sociedade de corte cujos valores como honra e prestígio eram fundamentais. A cada doação, a visibilidade pública desses ricos negociantes - seja através da publicação de seus nomes nos folhetos da secretaria dos negócios do Reino, seja pelas páginas da Gazeta do Rio de Janeiro - era colocada diante da possibilidade da conquista de novas mercês.

Durante o beija-mão, os trajes e as nobres qualidades eram essenciais. Quem optasse por cumprir esse ritual tinha plena consciência de que vivia em uma sociedade de corte rigidamente marcada por uma hierarquia dos lugares sociais. Aqueles que não tivessem casta de fidalguia aguardariam na segunda sala enquanto os nobres vassalos beijavam as mãos do monarca na sala principal, onde estavam presentes titulares e ministros reais. Tal era a importância desse ritual para a sociedade de corte que duas vezes por semana o ministro Tomás Antonio Vilanova Portugal recebia os pedidos das mercês.

5 BNRJ. Relação das festas que se fizeram no Rio de Janeiro, quando o príncipe Regente N.S e toda a sua família chegarão pela primeira vez áquella capital. Ajuntando-se algumas particularidades igualmemte curiosas, e que dizem respeito ao mesmo objeto. Lisboa, Impressão Régia, 1810, p.10. Seção de Obras Raras, [36,0,21]. 
N. ${ }^{0}$ I I.

\section{GAZETA Do RIO DE JANEIRO.}

QUARTA FEIRA I9 DE OUTUBRO.

Dwirina . . vim premevet iasitam,

Rectigae cultas pectora reberant.

HORAT.

T OS É Antoninuajāo da sobscrips̆ăo dos Commerciantes.

- Francisco José das Neves.

Manoel Ignacio de Souza Araujo.

$6 \mathrm{~d} 400$

Joáo Antonio de Castro Palma.

Francisco Joaquim de Lima.

José Pereira da Silva Guimaráes.

Manoel Joaquim de Azevedo.

Manuel de Moura Guimaries

Nicoláo Joaquim Perétá da Silva.

Joáo António de Fteitas. -

Rudrigo Jose Lopes. "-

Françisco" Jósé d' Almeida Lima.

Antonio de Söıza Pinto.

Antonio Pinheiro Guimaráes.

Continuar-se-ba.

120800

$4 \otimes \infty \infty$

$4 \$ 000$

60400

6 d 4 co

$4 \$ 000$

$8 d 000$

60400

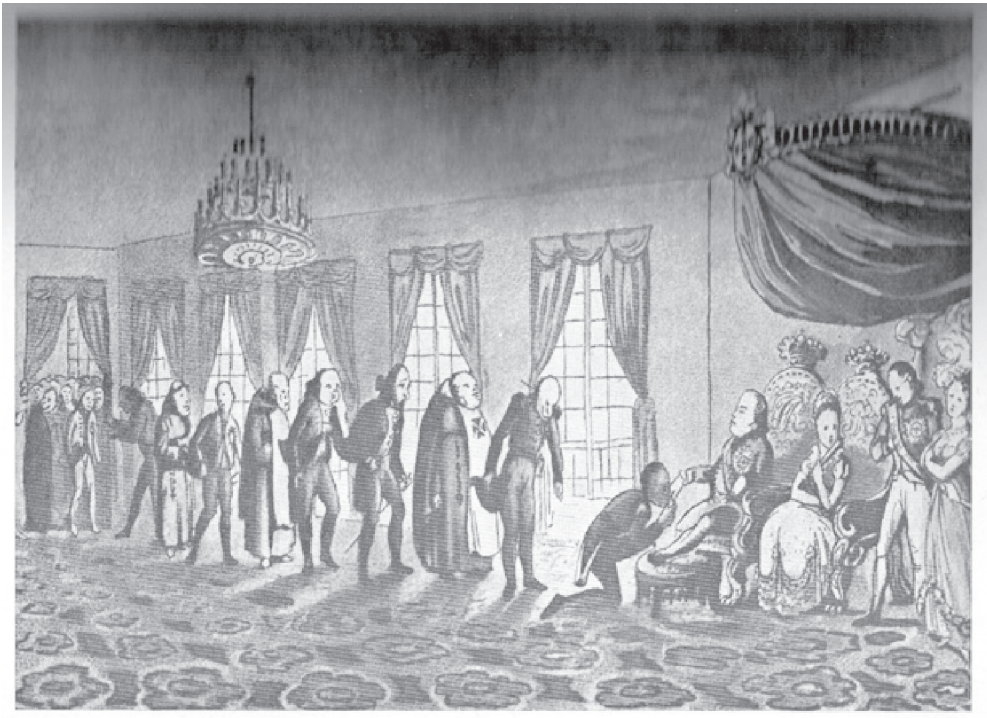


Logo nas primeiras edições da Gazeta, em 1808, era publicada a subscrição e os valores doados pelos vassalos da Coroa em prol do socorro dos súditos portugueses que ficaram no Reino à sorte dos franceses. Esses mesmos vassalos eram aqueles que cortejavam dom João cotidianamente à espera de benesses e também aqueles que patrocinavam os projetos culturais da monarquia nesse lado do Atlântico.

O caso da construção do Teatro de São João é emblemático. Os comerciantes de grosso trato do Rio se mobilizaram a fim de angariar fundos para que a capital do Império tivesse uma casa de espetáculos à sua altura. Para o sucesso do empreendimento, criaram um sistema de loteria - uma contribuição fundamental dos vassalos de dom João para a construção e sucesso do espaço - que ficava sob a responsabilidade de Fernando Carneiro Leão, proeminente negociante que neste caso respondia pelas contas e pelos prêmios.

Continua; äo da Relaçäo das Pessoas, que tem concorrilo para soccorro- dos Vassallos de S. A. R. residentes em Portagal desde 20 de Outubro ate 7 de Novembro.

O Capitáa Francisco José Ignacio da Silva.

O Reverendo Antonio José Escudeiro Ferreira de Souza. Em papel Moeda.

$16 \$ 200$

José Pinco de Miranda.

O Brigadeiro Domingos de Azevedo Coutinho Mello Soares Xinxorro.

O Coronel Joaquim Vicente dos Reis.

Fstacio Gularte Pereira.

Felisberto José de Almeida.

Antonio Pedro Teixeira.
Torcato Soares Loureiro, Official da Secretaria da Meza do Dezem-

bargo do Paço.
Hum Espadim de ouro de filagrana, offerecido por hum Patriota pa-
ra ser dado á pessoa que mais se distinguir na Restautaçáo de Lisboa.

Continuar-se-ba.

(Gazeta do Rio de Janeiro, 23 de novembro de 1808, n.21)

O Teatro São João, inaugurado em 1813, substituía a Casa de Ópera da cidade e foi um empreendimento amplamente noticiado na Gazeta do Rio de Janeiro, que informava sobre as datas do pagamento das loterias. Sob a direção do músico e mestre de empresas teatrais Bernardo José de Sousa e Queiroz, a peça O juramento do numes - de autoria de Gastão Fausto da Camara Coutinho - inaugurava as atividades que ocorreriam a partir de então no teatro. A peça exaltava a bravura do povo português, ainda imerso nas complexas consequências das guerras napoleônicas. A cena final retratava o tempo de heroísmo desse povo que jurava fidelidade ao Príncipe, cujo retrato aparecia ao fundo do palco. 
Perante a vossa Efígie augusta e sacra

Vasto Soberano de Nações diversas,

Cujo braço ostentoso alcança, e rege

Os hemisférios dois com as rédeas fulvas;

Perante a vossa Efígie e sobre as aras

Onde o eterno fulgor as nuvens doura

Juramos pelo escuro Estigio lago,

Nós, do grão Rei dos Reis, família e sangue

Que os Povos de Ulisses esclarecidos

Inquietados serão, mas não vencidos.

(apud Malerba, 2000: 112).

A partir de 1813, portanto, o gosto do Príncipe Regente pelas representações cênicas foi sendo popularizado e, aos poucos, tornou-se acessível a muita gente: peças teatrais, concertos musicais e uma ampla gama de produções artísticas encenadas por artistas europeus acabavam por englobar a sociedade fluminense, agora em estreito contato com valores "civilizados". Como bem observou Jurandir Malerba, havia uma continuidade entre o palco, o púlpito, a rua e o palácio real, uma vez que os mesmos símbolos circulavam por toda a cidade (Malerba, 2000: 93).

Obviamente que o Teatro São João foi um espaço concebido para o divertimento das classes abastadas intelectual e financeiramente: por lá convergiam homens e mulheres da nobreza portuguesa, assim como os ricos comerciantes cariocas e suas famílias. Aos escravos e aos homens livres pobres, o ingresso à nova arena de encenações no campo da arte $\mathrm{e}$ da política ainda era um sonho a ser conquistado. Porém, a despeito das etiquetas e hierarquias da corte, intrínsecas ao Antigo Regime, o fato é que o teatro já nascia como um ponto de reunião mundana que permitia a crítica dos costumes pela evocação de múltiplas vozes.

A consolidação desse espaço foi tão forte que a partir de 1821, sobretudo durante o processo de Independência, já era nítida a teatralização da política nos palcos. "Sem ser lugar de deliberação das autoridades, nem ponto predefinido para encontros políticos, a sala de espetáculos foi tornandose um canal da expressão de diferentes vontades coletivas. Muitas vezes indiferentes à peça teatral representada, os espectadores podiam chamar mais atenção do que os atores no palco", esclarece-nos o historiador Marco Morel (2005: 233).

Ainda em 1813, foi criada a Escola Cirúrgica e, no ano seguinte, era aberta ao público a Real Biblioteca. Ao institucionalizar o acesso à leitura e a um amplo universo cultural vigente no Velho Mundo, também a biblioteca inaugurava novos hábitos e práticas culturais. Mapas, canetas de pena, 
tinteiros, estantes recheadas de livros, papelarias passavam a fazer parte do cotidiano das pessoas. $\mathrm{O}$ conhecimento de um novo universo ao alcance das mãos trazia consigo a possibilidade das ideias de sedição no campo da política. O raiar desse espaço público fazia agora parte de um mundo que transcendia o rigor que a proibição das leis e a atuação dos censores poderiam prever.

Nesse cenário, Silvestre Pinheiro Ferreira redigiu um compêndio publicado entre 1813 e 1820 . Sob o título de Preleções Philosophicas, os escritos do Ferreira (um dos principais conselheiros de dom João no Brasil, além de diretor da Gazeta do Rio de Janeiro e ministro régio) difundiam a importância dada à retórica, concebida como um instrumento cotidiano de argumentação e convencimento. Os interessados em estudar as Preleções tinham a oportunidade de cursar as aulas de Ferreira, ministradas no Real Colégio São Joaquim. O início e conteúdo das aulas foram difundidos na seção de avisos da Gazeta.

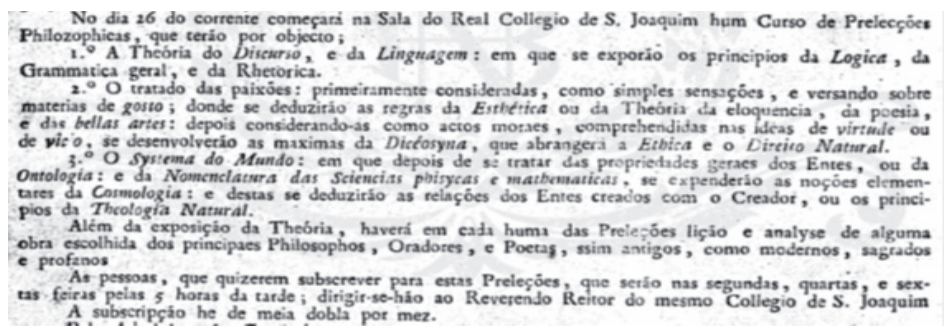

(Gazeta do Rio de Janeiro, 14 de Abril de 1813, n. 30)

As Preleções evidenciam um importante avanço no enraizamento da cultura erudita no Brasil, não só pelo fato de disseminar um conhecimento mais teórico acerca de novas possibilidades de estrutura de pensamento filosófico, mas justamente porque foi produzida por um dos pensadores portuguêses de maior destaque do século XIX, segundo a ótica do escritor e historiador português Alexandre Herculano (1938: 176-177).

Além dessas instituições de grande importância científica e cultural, vemos ainda o florescimento de outras iniciativas reais que muito contribuíram para o debate de ideias no espaço público no período. Manuel Ferreira de Araújo Guimarães, homem de letras de grande expressão do Império Português, lançava, em 1813, o primeiro jornal literário, O Patriota, que circulou até fins de 1814. Os artigos de caráter científico e literário, publicados no jornal, tinham como intuito formar os leitores de uma maneira geral, além de serem direcionados especificamente para agricultores, homens de ciência e escritores. 
Os subscritores e leitores do jornal eram pessoas ilustríssimas da Corte. Se da realeza contam entre os assinantes a princesa Carlota Joaquina e a Infanta d. Maria Isabel, da nobreza pululavam os nomes de grande destaque nos círculos da órbita monárquica, como os barões de São Lourenço e do Rio Seco, os condes dos Arcos, de Bel Monte, Galvêas, os marqueses de Borbas e de Torres Novas, entre tantas outras personalidades da alta nobreza joanina. Mas como bem nos alerta o historiador Marco Morel, o que estava em jogo era a consolidação de uma camada de homens de letras. Como leitores, esses sujeitos davam um passo à frente na formação de um público privilegiado de redatores ou de escritores públicos, como se dizia na época. "Sábios", "literatos", "ilustrados”, “esclarecidos" se colocavam como agentes mesmo sem a legitimidade de se constituírem como força moral e crítica para interferirem nos negócios públicos. Nesse princípio do século XIX, tal posição era uma espécie de nostalgia da República das Letras que brilhara no século anterior, mas acenava para um plano efetivo de relações naquela sociedade" afirma Morel (2007: 32). Pelas páginas de O Patriota, esses ilustrados refletiam sobre os novos (e múltiplos) sentidos da Pátria que nascia nas duas margens do Atlântico luso-brasileiro, concebida também como um lócus de discussão e prática de novas posturas singulares inseridas sob a perspectiva do Iluminismo luso-americano, imerso no universo imperial português (Kury, 2007: 141-142). No prospecto do jornal, Araújo destacava o diálogo cultural com a Europa, a nova ordem que desejava constituir no espaço público. A produção do jornal e a cooperação da sociedade nesse projeto, afirma o editor, "nos vingar[ão] da acusação de ineptos, que nos fazem autores estrangeiros, e por desgraça alguns nacionais."

Se, por um lado, todas essas iniciativas e transformações também apareciam no comportamento político da sociedade joanina que, desde a chegada da corte, tinha um amplo universo cultural ao seu alcance; por outro, a estruturação e funcionamento dessas instituições régias estavam estreitamente vinculados a um projeto político administrativo do Império Português, cujas raízes remontam aos debates do século XVI.? Para além

\footnotetext{
6 Ferreira. BNRJ, OR/ DOC 37,5 1B.

7 Para o debate historiográfico sobre esse tema, consultar, entre outros: PONDÉ, Francisco de Paula e Azevedo, "D João VI e a emancipação intelectual do Brasil", in Revista do Instituto Histórico e Geográfico, Rio de Janeiro, tomo 279, 1968, p.114. LIMA, Oliveira, Dom João VI no Brasil, $3^{\text {a }}$ ed., Topbooks, 1996. ALEXANDRE, Valentim, Os sentidos do Império: questão nacional e questão colonial na Crise do Antigo Regime Português, Edições Afrontamento, Lisboa, 1993; LYRA, Maria de Lourdes Viana. A utopia do poderoso império: Portugal e Brasil:bastidores da política (1798-1822), Rio de Janeiro, Sete Letras, 1994. MAXWELL, Kenneth, Pombal: paradox of the enlightenment, Cambridge University Press, Cambridge, 1995. BITTENCOURT, José Neves, "Iluminando a Colônia para a Corte: o museu real e a Missão Francesa como marcos exemplares da política de
} 
desse propósito, a real transladação da monarquia no início do século XIX também desejava atingir metas culturais mais amplas sob a perspectiva de um "projeto civilizatório" que visava à ocidentalização da América Portuguesa. A tônica seria a importação de padrões civilizatórios europeus como uma tentativa de inserir essa parte do mundo no Ocidente, sendo o Rio de Janeiro transformado em um autêntico laboratório de civilização sob a perspectiva de uma Europa possível (Santos, 2000: 9-10).

administração portuguesa no Brasil", in Seminário Internacional Dom JoãoVI: um rei aclamado na América, Rio de Janeiro, Museu Histórico Nacional, 20oo, p. 114-121. 
II.

SOCIABILIDADE E CONFLITO NO RiO DE JANEIRO JOANINO

A nova sociabilidade vigente na Corte, assim como os conflitos decorridos dessas transformações na organização do espaço público, aparecia nos múltiplos universos dos atores sociais. Das novas práticas alimentares às múltiplas formas do convívio entre o universo escravo e a sociedade de corte que se formava nos trópicos as mudanças são visíveis.

\section{A ALIMENTAÇÃo E A SOCIABILIDAdE COTIDIANA À MESA}

Durante todo o período em que a corte esteve por nossas terras, a alimentação foi uma temática de muita relevância para a população da cidade do Rio de Janeiro. Nos anúncios publicados na Gazeta encontramos uma variedade enorme de venda de alimentos: fosse os importados da Europa ou aqueles produzidos no Brasil, o fato é que, com a ampliação do universo culinário, surgiam novos hábitos culturais que delinearam, ao longo dos anos, novas formas de sociabilidade à mesa.

Preços de Mercadorias no Rio, início do Século XIX

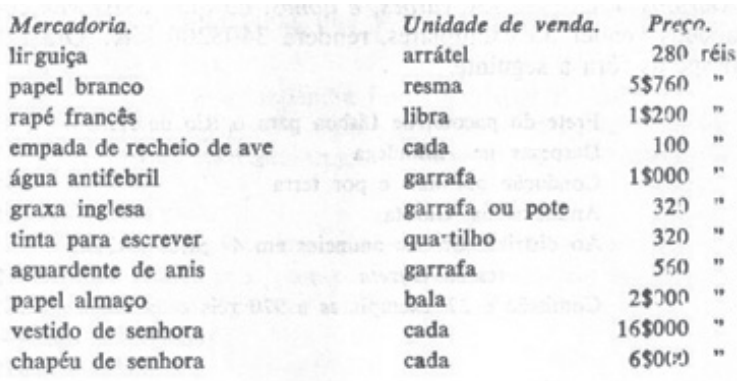

(Fonte: SILVA, Maria Beatriz Nizza da. Livro e Sociedade no Rio de Janeiro (1808-1821). Separata da Revista de História, n. ${ }^{\circ} 94$, São Paulo, 1973.)

Em 18 de dezembro de 1813, por exemplo, eram publicados no jornal os diversos produtos alimentícios que podiam ser encontrados na loja de Luís Zoveti e Cia., na rua do Ouvidor, n. 9. Mostarda, conservas inglesas ditas 
de "qualidade", molhos para peixe, azeite engarrafado vindo de Florença, diferentes vinhos estrangeiros, frutas em aguardente, chás, doces e chocolates eram gêneros anunciados pelo proprietário do estabelecimento. A venda de produtos exóticos também já fazia parte do cotidiano da população. Em novembro de 1814, a Gazeta anunciava a venda de tâmara, fruta até então desconhecida no Brasil e que tinha grande estima nas mesas de sobremesas europeias.

O contato cada vez maior com a cultura europeia também estimulava um novo hábito na Corte: difundia-se o costume de almoçar fora de casa, nas denominadas casas de pasto, que serviam diariamente diferentes cardápios pré-estabelecidos com preços também já previamente fixados pelo comerciante. Tais mudanças na prática incentivam a procura por cozinheiros, um ofício bem remunerado. Em 1808, "um cozinheiro que soubesse trabalhar de caçarolas e massas ganharia por mês $14 \$ 000$ réis, mais do que muitos letrados obtinham em suas aulas", elucida a historiadora Maria Beatriz Nizza da Silva (2007: 35). A sobremesa teve seu espaço garantido. Em julho de 1813, Vicente Ferreira, o ilustre chocolateiro da princesa Carlota Joaquina, abria uma fábrica de chocolate na rua do Ouvidor, n. 28. Para além da venda de todas as qualidades de chocolate, a loja vendia ainda extratos de manteiga de cacau para a produção de outros doces (Gazeta do Rio de Janeiro, 1813, $\mathrm{N}^{\circ}$ 58). A diversidade e a quantidade dos gêneros que foram importados nos Reinos de Portugal e Brasil durante 1816 foram tema de destaque da folha oficial, tamanha era a preponderância do comércio interatlântico de alimentos dentro dos limites do Império Português.

"O comércio ambulante, estimulado pelas feiras livres e as negras quitandeiras, aparecia como modo de abastecimento fundamental nesse período, permitindo enxergar outros alimentos que compunham um rico cenário alimentar (...) Tratava-se, de certa forma, de uma alimentação baseada em tudo o que a terra podia oferecer, embora já adaptada e reelaborada de acordo com os diversos paladares que por ali conviviam", analisa a antropóloga Paula Pinto e Silva (2008: 6). As transformações na vida cotidiana da Corte chegavam para ficar. 
Resumo de todos os effeitos, que no decurso do anno passalo for $\bar{a} 0$ importados dos Reinos de Portugal, do Brazil, $e$ das suas dependencias, no de Hamburgo.

Assucar 17:028 caixas, 109 fechos, 141 batrís, 22 sacas.

Agoardente de cana $3 \mathbf{1}$ pipas, 10 barrís.

Algodāo 1:14t fardos, 2310 sacas. - Dito fabricado 39 volumes.

Amendoas 4 barrís.

Arroz 5 barris, 2:747 sacas.

Anil 16 caizas.
Azeite 3 barrís, 4 caixas com dito enfrascado, I jarro.

Azongue 550 frascos.

Baga 122 sacas.

Balsamo 32 barris. - Dito de Copaiva 6t barrís.

Borra de vinbo 6 barrís.

Cacdo r: 273 sacas.

Caffe 2:580 ditas, 25 fardos.

Canella 4 caixas, $t$ dito.

Casca de lananja 16 ditas, 13 sacas.

Cassia lignea 81 caixas.

Cebollas $4 \mathrm{I}$ cestos.

Cerdas de cavallo 43 fardos.

Cod 3:18t caixas inteiras, meias, a quartas.

Chocolate 7 ditas.

Cobre 287 barris.

Cortiçd 528 quintaes.

Couros 31:377.

Curcuma 29 sacas.

Doces 12 caixis.

Drogaria 22 barris, 6 fatdos, 14 volumes.

Figos passados 40 barrís, 100 ceiras, 300 arrobas. Fulbas de loturo 135 fardos, 767 sacas.

Frata 7078 caixas, 909 meias ditas.

Gengibre 300 sacas.

Gommas 18 barrís, 27 sacas.

Dita elastica 12 ditos, 37 ditas.

Jpecacuanba 1 barril.

bï 6 bilóes:

Licores 43 caixas .com frascos.

Lixa 2 fardos.

Toucta 1 caixa.

Melaço 8 bartis.

Pato amarello 2:200 arrobas, P. m. of m.

Dito Brazil 1:108 trancas.

Dito campecbe huma partida.

Ditonebano if francas.

Pacs diversos de timura $4: 090$ trancas.

Passas 500 caixinhas.

Rimienta 15 fardos, 35 sacas.

Pontas de boi $321: 762$, e 2 partidas. - 6:200 chapas. Pontinhas dito $15: 942$, 50 batris,

Rolbas 8 fardos.

Sal 288 moios, e I partida.

Salsa pitrilba 4 : fardos, 9 sacas.

Sassafraz; 1 partida.

Sebo 80 barris, 110 marquetas.

Tabaco 133 ditos, 5:590 balóes, 776 fardos, e 4:564 rolos.

Dito em pó a caixa.'

Tapioca 135 barris, 700 sacas.

Evas 20 caix 15,6 meias dias, 35 jarros.

Vinbo $17^{8}$ pipas, 170 meias, 111 quartolas, 11 caixas com dito engarrafado, 37 barris vátios.

$V a r i a s$ fazendas e effeitos: anonimos 14 caixas, 16 barrís, 1 fardo, 11 sacas, 4 volumes.

(Fonte: Gazeta do Rio de Janeiro, 19 de julho de 1817, n.58.) 
Paralelamente à formação desses espaços culturais que garantiam um novo locus de sociabilidade, o cotidiano da Corte também era marcado por tensões e conflitos sociais que permeavam a vida dos escravos, que viviam a complexa realidade de habitarem na cidade sob a escravidão urbana.

Ser escravo ou escrava nos centros urbanos do Brasil no raiar do século XIX significava viver sob a forma de ganho, prática que lhes conferiam uma importante - mas relativa - mobilidade pela cidade. $\mathrm{O}$ trabalho sob a condição de ganho era exercido cotidianamente e não tinha a interferência explícita do senhor: este recebia ao final do dia ou do tempo fixado a quantia por ele previamente estabelecida.

No dia a dia, ao disporem provisoriamente de sua força de trabalho, os escravos desempenhavam diversas funções, tais como ama de leite, jornaleiro, sapateiro, doceiro, padeiro, cozinheiro, vendedor ambulante, marceneiro, carpinteiro etc., que eram comumente comercializadas na cidade por aqueles que detinham o seu pátrio poder. Não raro, os proprietários descreviam as "qualidades" de seus escravos quando desejavam vendê-los rapidamente. Em 1813, por exemplo, era anunciada a venda de um cativo dito bom barqueiro e canoeiro com amplas habilidades para marinheiro, que não continha vícios, defeitos físicos ou doenças (Gazeta do Rio de Janeiro, 1813, $\mathrm{N}^{\circ} 27$ ). Escravas cozinheiras, engomadeiras, costureiras e amas de leite também adquiriam grande valor no mercado, já que tinham todos os dotes necessários para realizarem o bom serviço de uma casa (Gazeta do Rio de Janeiro, 1820, $\mathrm{N}^{\circ} 60$ ). Mas independente de praticarem um trabalho especializado, os escravos urbanos - na maioria das vezes - passavam o dia longe das vistas do senhor. "[Essa situação lhes] permitia também um maior contato com os demais grupos da sociedade, o que lhes facilitava estarem continuamente informados sobre os acontecimentos e às vezes conhecerem alguns de seus poucos direitos", elucida a historiadora Leila Mezan Algranti (1988: 20).

$\mathrm{O}$ amplo contato desses cativos com a população livre era um fator de grande temor social. A constante ameaça de rebelião contra o sistema escravista amedrontava os demais grupos sociais que concebiam os negros - cativos ou libertos - como suspeitos ou criminosos em potencial. Apesar do alto policiamento, uma gama enorme de atentados à ordem pública era comumente praticada na cidade. A maioria das ocorrências como os roubos, crimes e assassinatos recaíam sobre os escravos, que não tinham a quem apelar. Ao contrário, tinham seus passos vigiados pelos juízes de crime dos bairros que informavam Paulo Fernandes Viana sobre os "distúrbios" cotidianos. 
Fugas e revoltas coletivas organizadas era uma realidade que deveria ser denunciada a fim de melhor vigiar, controlar e punir esses sujeitos. Diante desse cenário, muitos proprietários publicavam anúncios na Gazeta do Rio de Janeiro com o intuito de reaver "a perda de seus bens"; atitude que conferia ainda mais visibilidade à situação desses escravos.

Em fevereiro de 1817, saía publicado na Gazeta um anúncio sobre a fuga de uma preta de nome Manoela. A narrativa detalhava não só a data da fuga da escrava (20 de outubro de 1816), como também a descrevia por completo: vinda de Moçambique, Manoela contava com 14 anos de idade, tinha feições bonitas, delgadas de corpo, braços longos, pé comprido (sic) e dentes limados. A vestimenta da escrava no dia da fuga foi vivamente rememorada: sumira de vestido branco, com roupinhas de folhos. Àquele que achasse a escrava, José Rodrigues do Orte, seu proprietário, prometia boas recompensas (Gazeta do Rio de Janeiro, 1817, $\mathrm{N}^{\circ} 13$ ).

Três anos depois, em 1820, o desaparecimento de cinco escravos de Moçambique e do Congo, que trabalhavam na fazenda de Santo Antonio, na freguesia de Jacutinga, também foi motivo para a publicação de um anúncio na Gazeta. O texto denunciava a estratégia da fuga que parecia ter sido previamente planejada: os cativos vestiam carapuças encarnadas e mantas brancas de algodão de Minas, o que supostamente os identificariam como fujões. O proprietário garantia boas gratificações para quem deles dessem notícia ou os conduzisse à fazenda (Gazeta do Rio de Janeiro, 1820, $\mathrm{N}^{\circ} 80$ ).

Outro viés muito presente no cotidiano escravista da Corte foi a capoeira, uma prática de defesa e ataque trazidos pelos africanos ao Brasil que muito incomodava a sociedade cortesã carioca. Designada na época como jogo, a capoeira era composta por rápidos movimentos em que o capoeira golpeava seu adversário com a cabeça ou com as pernas. As mãos serviam para o apoio no chão quando o "jogador" atirava os pés na direção do antagonista, atingindo-o em cheio. Foram tantas as inconveniências causadas pelos capoeiras que d. Pedro, em 6 de fevereiro de 1822, escreveu do próprio punho uma carta ao brigadeiro Carlos Frederico Bernardo de Caula. Ao mesmo tempo em que o documento exigia medidas enérgicas e violentas contra os capoeiras, também cedia vantagens aos soldados que conseguissem prender os cativos que estivessem capoeirando.

Meu Caula,

Mande passar uma portaria ao Comandante da Guarda da Polícia em que se lhe estranhe muito da minha parte, o pouco cuidado que tem tomado, em prevenir as capoeiragens pelas ruas que tem chegado a ponto de quebrarem vidros das janelas e na mesma Portaria autoriza-lo para que logo se agarre qualquer capoeira que seja escravo na ação de capoeirar seja logo conduzido 
imediatamente ao moirão mais próximo, e aí surrado com 100 açoites, e depois entregue ao Senhor se na tiver feito mais nada que capoeirar, e na mesma ordenar ao comandante que todo o soldado que apanhar um capoeira terá quatro dias de licença, e assim na proporção de quantos agarrarem capoeirando.

Deste seu amo e amigo

Pedro (apud Prado, 1968: 254).

Geralmente, a habilidade e a rapidez dos golpes era motivo de grande apreensão por parte dos policiais que, na maioria das vezes, tinham dificuldade de se defenderem, o que causava muita correria e grandes tumultos na cidade. A notícia que correu pela cidade em 2 de abril de 1814 mostrava com exatidão a amplitude desses conflitos vividos no cotidiano das ruas. A Intendência Geral da Polícia tornava público que no Calabouço (prisão da cidade) havia 34 escravos fugidos que tinham sido achados em quilombos ou mesmo fora deles. A lista publicada na secretaria da intendência informava aos senhores que a partir daquela data já podiam ir verificar se eram identicamente os próprios, para os receberem no prazo de três meses. Destacava, ainda, que os escravos que não tivessem seus donos apresentados seriam entregues ao Magistrado, responsável por arrecadar "os bens", vendendo-os, sendo que o produto líquido das despesas deveria ser entregue para os cofres do fisco (Gazeta do Rio de Janeiro, 1814, $\mathrm{N}^{\circ} 27$ ). Ao cultivarem essas práticas e códigos culturais intrínsecos ao universo escravo, muitos cativos eram violentamente reprimidos, o que, por fim, era um motivo a mais de aprofundamento dos conflitos intrínsecos ao sistema escravista.

O universo feminino também sofreu muitas transformações durante o período joanino. Com o estabelecimento da corte, uma ampla gama de novidades passou a fazer parte da vida cotidiana das mulheres: dos livros publicados pela Impressão Régia ao oferecimento de trabalho doméstico, houve um grande incremento nas ofertas de diversos produtos importados vindos da Europa e nas oportunidades de aprimoramento cultural.

Vendas de novelas com enfoque moral como O bom marido, $A$ boa mãe, A má mãe, Duas desafortunadas, Triste efeito de uma infelicidade, Amor ultrajado, Castigo da Prostituição, Infelicidade vingada, As mulheres célebres da Revolução, ou Quadro enérgico das almas sensiveis etc. eram títulos geralmente anunciados na seção de Avisos da Gazeta (Gazeta do Rio de Janeiro, 1817, $\mathrm{N}^{\circ}{ }_{17}$ ). Além de livros com temas femininos, o anúncio de joias, roupas e utensílios de origem francesa e inglesa recheava as páginas da folha. Em 1817, o comerciante Joaquim Martins Pinto, residente na rua Direita, anunciava a chegada de vestidos de seda de todas as cores, lavrados de ouro, prata e matiz. Cambraias bordadas, ornamentos para cabeça, muitos xales de lãs e 
gargantilhas, eram todos ornamentos chegados da França (Gazeta do Rio de Janeiro, 1817, $\mathrm{N}^{\circ} 85$ ). Quanto à oferta de emprego, muitas mulheres livres eram procuradas para o trabalho doméstico. Em 1820, Antonio Ferreira da Rocha procurava uma governanta branca ou parda com reconhecida capacidade doméstica para tratar do asseio da casa onde habitavam um homem viúvo e seus três filhos (Gazeta do Rio de Janeiro, 1820, $\mathrm{N}^{\circ} 25$ ).

A chegada de mulheres estrangeiras também se tornava uma realidade. Por aqui afluíram as senhoras da nobreza portuguesa, as esposas e filhas dos viajantes, as atrizes que vinham encenar peças de teatro e óperas no Real Teatro, assim como as profissionais liberais. Em maio de 1820, a modista inglesa Hannah Hairris, que tinha sua loja na rua do Ouvidor n. 17, anunciava a "preços cômodos" o recebimento de diversos objetos femininos vindos de Londres e Paris. Entre aqueles considerados de maior apreço, destacava os chapéus pretos de palha inglesa, vestidos bordados de filó de ouro e prata, e rendas de ouro e prata e pérolas (Gazeta do Rio de Janeiro, 1820, $\mathrm{N}^{\circ} 39$ ).

A multiplicidade de códigos e costumes culturais tão singulares aparecia de diversas formas no cotidiano do universo feminino. O papel das mulheres pertencentes às altas camadas da sociedade se restringia ao universo privado da casa. Como provedora dos alimentos da família, ficava também no comando da escravaria, além de ter em suas mãos a supervisão da educação de seus filhos. Quanto aos hábitos mais comuns, se ocupavam dos trabalhos manuais: bordar, fiar, costurar e tecer sempre foram atividades altamente indicadas às mulheres tanto pelos moralistas como por aqueles que se preocupavam com a educação feminina. Nesse período, havia a concepção de que a prática do uso das mãos femininas era uma forma eficaz de se evitar a ociosidade e, por consequência, os maus pensamentos e ações, razão pela qual elas raramente saíam de casa desacompanhadas de seus maridos ou escravos (Algranti, 1997: 122). Quando saíam, geralmente era para cumprir um importante ritual religioso: assistiam à missa, que ocorria às 4 horas da manhã.

Por outro lado, a valorização da educação feminina em outros espaços que não fosse o ambiente doméstico começava a ganhar terreno na cidade, inclusive pelas mãos de senhoras distintas da sociedade. O caso de D. Catarina Jacob é emblemático: em dezembro de 1812, a senhora informava ao público a abertura de uma academia para instrução de meninas que privilegiava justamente o ensino dos bons manejos das mãos e o cuidado com a casa. $\mathrm{O}$ aprendizado das Artes como a dança e a música seriam pagos à parte. 


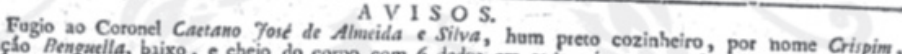

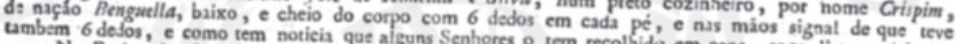

Na Botica de Antonio Joaguin de siva Genhores o tem recolhido em caza, foza lio participem.

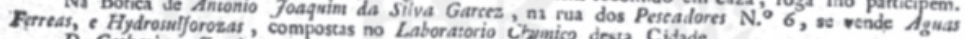

D. Cabarina Tarob toma libendade

Academia para instrucçáo de Meaiass na rua de fazet sciente ao Publico, que ella tem estabelecido huma a let, escrever, e fallar as lingus Portugueza da Lapa, defronte da Ex. ina Duqueza, em que ensinuri bordar, e o manjo da Caza. Esta esperancada que, $\mathrm{cm}$ conseguenciasts ; toda a qualidade de costura e eiçá, Religia, e Moral, mereceri eternamente que, em consegnencia do seu cuidado, e atvençio na edafiarem esta honta : cada Menina cópo de prata, pagario por ead tráa a cana compteta, tres toalhas de máos, hum talher completo, e msate todas as pessoss, quz cada Menina dezoito mil rtis por mez, sendo a quarteis adiantados. Igule go á parte; mandario todos os Sabhados os stus Meninis aprendio Muziea, Dança, e Desenho, serí pa. mudança, fizulmente as peisoas quequiz os stus criados ao Collegio com roupa necessuria para se fazer car 'as suas Meninis. Collegio: poderi haver modifica gio a tespeito de familte do masmo Domingo ou dia Santo se recollhio ao comodo, o-saprir aos oito dias com roupa abertura do Collegio deveri ter principio no o outra alguma couza; para o que fará particulat ajuste. A Com este mez aeabia ter principio no primeiro de Jansiro de 181 .

devem ditigir-s: a L Loj de Paulo Martin, Fibo do segundo semestre do corrente anno, e darante elle, sejio remeitidas as Gazetss no proxims seguinte stmenta da Quitand $i$, as pessoas, que dezejarem que the: para a pronta entreza de cada huoxims seguinte stmestre. As providencias, que ultimamente se tem dado quaesquet, qua forem conducentes ás Numsros, se continuario na nova subscripḉo, e se daráo outras e Listas de daspachos, ficarío (como dasteşa do Publico. Todas as Gazetas Extraordinurias, ou Dohradis, com preferencu hum exemplar de dalivas pertencendo aos Subscriptores, a quen igualmente se remerters se faz a subseripcío para o novo gornal o Patrio que se haja de distribuir gratuitamente. Na mesma Loji

Sexta feira 18 do cotrente haverí Gazeta Extraordinaria, N. ${ }^{\circ}$ to.

$$
\text { RIO DE JANEIRO "A IMPRESSXO REGIA. } 1812 .
$$

(Fonte: Gazeta do Rio de Janeiro, 1812, No 101).

Particularmente, no caso das viúvas, essa situação era amenizada: ao terem que cuidar dos negócios do falecido marido, tinham suas vidas também voltadas à arena pública. Em fins de novembro de 1819, um caso intrigante aparecia nas páginas da Gazeta. D. Ana Barbosa de Miranda, testamentária de seu esposo falecido, com a ajuda de seu pai - o tenente coronel Antonio José da Costa Barbosa -, avisava a sociedade sobre a demolição das casas erguidas por Diogo Teixeira de Macedo nos terrenos de sua propriedade. $\mathrm{Na}$ publicação, informava a sentença da justiça a seu favor, que lhes julgou próprio o terreno, uma vez que ela sofria problemas com Teixeira, já que este queria vender as casas e mais benfeitorias (Gazeta do Rio de Janeiro, 1819, N 94).

A presença e participação das mulheres também começavam a ser alvo de comentários na sociedade. A peça $A$ mulher inimiga do seu sexo, encenada no Real Teatro em junho de 1817, em meio às manifestações públicas que congratulavam o fim da Revolução Pernambucana, teve contornos interessantes das mulheres que a assistiam. Segundo a descrição do redator da Gazeta, o espetáculo começava com o hino nacional cantado pelos músicos da casa que viram também nas senhoras a expressão de espectadoras e acompanhantes fiéis do hino, entoando-o sob vivas e lenços, fosse da plateia ou do camarote (Gazeta do Rio de Janeiro, 1817, $\mathrm{N}^{\circ} 3$ ).

As profundas transformações socioculturais ocorridas no Brasil durante permanência da Coroa Portuguesa teriam contornos importantes na formação de uma nova concepção do espaço público. As ações dos diferentes sujeitos históricos no universo da política demonstravam claramente que o tempo da subserviência colonial ficara para trás. 
III.

\section{A elevação do Brasil a Reino Unido e a Aclamação de D. JoÃo VI}

Em dezembro de 1815, Dom João, ainda Príncipe Regente, elevou o Brasil à condição de Reino Unido a Portugal e Algarves. Coincidentemente, 1815 também fora o momento em que Napoleão Bonaparte deixava de ser, definitivamente, uma ameaça à Europa. Portanto, pela ótica dos súditos portugueses, não havia razões plausíveis para que o Príncipe Regente e a família real continuassem a habitar a América. Além disso, o fato de o Rio de Janeiro ser a capital do Império Português e o Brasil deixar, institucionalmente, de ser Colônia de Portugal amedrontava os fiéis vassalos portugueses que, independente dos seus lugares na sociedade, mostravam-se cada vez mais insatisfeitos por estarem relegados a um plano político periférico. Em 1817, os ministros do Reino, Marquez de Borba, Principal Souza, Ricardo Raimundo Nogueira e João Antonio Salter de Mendonça enviavam uma carta a D. João. O conteúdo do documento registrava, exatamente, o profundo pesar da sociedade lusitana pela ausência da realeza.

Não devemos porém, Senhor, ocultar a V. Mage., por nossa honra e obrigação, o descontentamento geral de todos os seus fiéis vassalos pela demora de V. Magestade no Reino do Brasil, depois dos ordinários sacrifícios e heroicidades que fizeram, para conseguirem a salvação da Monarquia e a pronta restituição de V. Mage. à antiga sede da mesma ... E todos suplicamos a Deus Nosso Sr. que inspire a V. Mage., que se compadeça da necessidade que temos da Sua Augusta Presença nestes Reinos para a conservação dos mesmos, e nosso amparo e se digne pela sua misericórdia disportudo de maneira que V.Mage. possavir com todaa brevidade. (ANTT, Ministério do Reino. Governadores do Reino. Registro de Cartas ao Príncipe Regente, Livro 317, Carta 466, 17.3.1817, fl. 377)

Se os burburinhos e discussões das múltiplas vozes anônimas dos súditos da monarquia pelas ruas de Lisboa entoavam a canção do retorno da realeza e sua corte, existiam também aqueles súditos que demonstravam o desgosto da situação na qual se encontravam, como ocorreu em 1818. Com uma retórica própria aos moldes do Antigo Regime, o súdito português dirigia-se a El Rei, intitulando-se seu fiel vassalo. 
Agora por nossa desgraça, estamos vendo os louros voltados, o que vinha do Brasil, para Portugal, vai agora de Portugal para o Brasil ... e não somos nós por ventura, vassalos de V. M. para sermos tratados pela mesma maneira que são hoje os brasileiros? que tão felizes se acham e nós em tanta desgraça? há muito bem pode V. M. socorrer-nos, quando não, será por tempos, V. M. Rei de um Povo mendigo, e desgraçado. (Carta de hum fiel vassallo a El rei D. João VI, relatando o estado do Reino de Portugal sob o governo regencial e pedindo a volta se S. M." Documentos para a História da Independência, 1923: 6)

Ambos os registros refletiam, em graus díspares, um sentimento coletivo de angústia e desesperança do povo português, que ganhava cada vez mais força desde 1814, quando as discussões sobre o (in)evitável retorno da realeza começaram a germinar em terreno fértil. Desde então, pelas duas margens do Atlântico os bastidores do alto escalão político da monarquia lusobrasileira versavam sobre os prós e contras acerca das controvérsias inerentes à permanência ou ao regresso. Em $1^{\circ}$ de novembro de 1814, em umas das cartas que, cotidianamente, remetia aos familiares no Reino, o bibliotecário real Luís Joaquim dos Santos Marrocos refletia sobre a estadia prolongada da monarquia no Brasil. "Quanto a novidades, a que eu, como povo possa chegar, devo dizer a V. Mcê. que vai nascer uma fermentação oculta, que solapadamente vai minando em preparativos nossa ida para Lisboa: no Arsenal da Marinha se trabalha em aprestos para as embarcações de guerra; estas estão se concertando e aparelhando". Mais à frente, Marrocos contava sobre a chegada de oficiais na cidade que, segundo ele, vinham ao Rio para ajudar os poucos oficiais que havia e, portanto, fixavam residência por tempo "indeterminado". As notícias oficiais ou os boatos que corriam pela cidade sobre a volta da monarquia eram a sua maior preocupação, conforme dizia ele: “(...) no Público não há nada de novo: S.A.R não fala, nem consente que se fale nisso; e é essa a razão porque ninguém se prepara nem cuida e tal. Uns dizem que a 17 de dezembro é que vem a publicar-se nossa retirada, e que esta se verifica para março; outros que para todo o ano futuro; outros finalmente afirmam que esta não se efetua enquanto for viva S. Majestade, ou enquanto não se preencher o tempo deste último tratado com a Inglaterra. Daqui pode V. Mcê. concluir o quanto estamos às cegas neste ponto." A carta de Marrocos sinalizava para uma questão política central do Império Português: Qual deveria ser o lugar hegemônico do poder no mundo luso-brasileiro?

A necessidade da resposta dessa questão fundamental se fazia urgente. Os habitantes do Reino, já libertos do domínio francês, ansiavam por reaver a antiga centralidade de Portugal na conjuntura do Império. Já no Brasil, os súditos, particularmente aqueles que habitavam a capital do Rio de 
Janeiro, viviam sob uma conformação de amplos interesses que englobava um status político-econômico que não podia ser abolido, revertido ou mesmo ignorado de uma hora para a outra. Apesar dessa intensa polêmica, em 16 de dezembro de 1815 D. João elevou o Brasil a Reino Unido de Portugal e Algarves, o que sinalizava para a sua permanência em terras americanas.

Elevação do Brasil à Categoria de Reino - Carta de Lei do Príncipe Regente D. João

\section{(18 de Dezembro 1815)}

Dom João, por graça de Deus Príncipe Regente de Portugal e dos Algarves daquém e dalém-mar, em África, da Guiné e da Conquista Navegação e Comércio da Etiópia, Arábia, Pérsia, Etiópia, etc. Faço saber aos que a presente carta de lei virem, que tendo constantemente em meu real (?) ânimo os mais vivos desejos de fazer prosperar os Estados, que a Providência Divina confiou ao meu soberano regime e dando ao mesmo tempo a importância devida à vastidão e localidade dos meus domínios da América, a cópia e variedade dos preciosos elementos de riqueza que eles em si contêm e outros em reconhecendo quanto seja vantajosa aos meus fiéis vassalos em geral uma perfeita união e identidade entre os meus Reinos de Portugal, dos Algarves, e os meus domínios do Brasil, erigindo estes àquela graduação e categoria política, que pelos sobreditos predicados lhes deve competir, e na qual os ditos meus domínios já foram considerados pelos plenipotenciários das potências que formaram o Congresso de Viena, assim no Tratado de Aliança concluído aos oito de abril do corrente ano, como no tratado final do mesmo congresso: sou portanto servido, e me praz ordenar o seguinte:

- Que dada a publicação desta carta de lei o Estado do Brasil seja elevado à dignidade, preeminência e denominação de Reino do Brasil

- Que os meus Reinos de Portugal, Algarves, e Brasil formem dora em adiante um só e único Reino debaixo do título de Reino de Portugal, e do Brasil, e Algarves.

- Que os títulos inerentes à Coroa de Portugal, e de que até agora hei feito uso, se substitua em todos os diplomas, cartas de lei, alvarás, provisões, e atos públicos, o novo título de Príncipe Regente do Reino Unido de Portugal, e do Brasil e Algarves daquém e dalém-mar (...) Dada no Palácio do Rio de Janeiro, aos dezesseis de dezembro de mil oitocentos e quinze. ([Carta] Regitrada nesta Secretaria de Estados dos Negócios do Brasil, L. ${ }^{\circ}$ 2. ${ }^{\circ}$ de leis, alvarás, e Cartas Régias à fl.69. Rio de Janeiro, em 16 de dezembro de 1815 ).

Esse novo status político do Brasil que, consequentemente remodelava sua importância e centralidade dentro do Império Português, colocava os brasileiros em pé de igualdade com os portugueses. Os lusitanos, no entanto, 
reagiram mal a essa transformação. Tinha até quem dissesse que uma nuvem negra de desgosto geral cobriu os corações dos habitantes de Portugal, vendo no governo todas as disposições de reduzi-lo ao estado de Colônia, quando se elevava o Brasil à graduação de Reino (Anônimo, 1863: 147).

Silvestre Pinheiro Ferreira, funcionário de alta consideração da Coroa, foi um dos principais conselheiros de D. João nessa delicada questão de Estado, que estava diretamente ligada à manutenção da integridade imperial. Refletia o estadista português:

A questão de Estado, que se agita sobre o regresso da Corte de V.A.R para a Europa e sobre a qual V.A.R (...) se há dignado de ordenar-me, que diga o meu parecer, é sem dúvida, um dos maiores problemas políticos, que jamais soberano algum teve de resolver. Porquanto nele se não trata simplesmente de saber, em qual dos vastos domínios de sua real Coroa convém mais, que V.A.R se digne de fixar sua residência; trata-se de nada menos, que de suspender e dissipar a torrente de males, com que a vertigem revolucionária do século, o exemplo dos povos vizinhos, e a mal entendida política que vai devastando a Europa, ameaçam de uma próxima dissolução, e de total ruína dos estados de V.AR., espalhados pelas cinco partes do mundo, quer seja pela emancipação das colônias, no caso de V.A.R regressar para a Europa: quer seja pela insurreição do Reino de Portugal, se aqueles povos, perdida a esperança que ainda os anima. De tornar a ver o seu amado príncipe, se julgarem reduzidos à humilhante qualidade de Colônia.

(Proposta autografada sobre o regresso da Corte para Portugal e providencias convenientes para prevenir a revolução e tomar a iniciativa na reforma política, In: RIHGB, tomo 47 , parte I, p.2.)

Silvestre Pinheiro Ferreira defendia a posição de que D. João deveria permanecer na América sob o título de "Imperador do Brasil". Porém, o ministro atentava para os perigos dos descaminhos de uma possível separação política: impunha, no que se referisse ao poder executivo, que este deveria ser exercido exclusivamente por D. João, nos dois lados do Atlântico. A fragilidade do sistema imperial, contudo, escancararia suas fissuras durante o ano de 1817.

\section{A Revolução Pernambucana (1817)}

Entre os meses de março e maio, a província de Pernambuco viveu uma importante insurreição política, denominada pelos revoltosos de revolução pernambucana. 
A composição do movimento era de natureza absolutamente heterogênea. Negociantes de grosso trato, diversos proprietários de terras, homens do clero (muitos deles formados no Seminário de Olinda), pequenos sitiantes, homens livres, boticários e, inclusive, escravos e negros se opunham à opressão $\mathrm{e}$, consequentemente, às dificuldades financeiras impostas pela Corte desde a sua instalação, através do aumento dos tributos pagos por Pernambuco. Além disso, a péssima condição das tropas militares - mal pagas e mal alimentadas -, eram fatores que contribuíam para que os habitantes da província tivessem uma imagem despótica do Príncipe Regente. A ala de negociantes contrária à revolução era, na maioria, composta por portugueses residentes em Pernambuco, vinculados ao comércio lusitano, que detinham o monopólio de suas produções como o açúcar e o algodão.

Ao conseguirem dominar o Governo Provincial, os líderes do movimento - o negociante Domingos José Martins, Antônio Carlos de Andrada e Silva, Padre João Ribeiro, o magistrado José Luís Mendonça, o representante da agricultura Manuel Corrêa de Araújo, o militar Domingos Theotônio Jorge Martins Pessoa - instalaram um governo provisório cujas propostas básicas eram a proclamação da República, abolição de alguns impostos e a elaboração de uma constituição que estabelecesse a liberdade religiosa e de imprensa, bem como a igualdade de todos os proprietários perante a lei. No tocante à abolição do regime escravista, acenava-se para o fim gradual da escravidão, que ocorreria em um futuro ainda incerto. $\mathrm{Ou}$ seja, entre as noções de igualdade e propriedade, os revoltosos defendiam mais veementemente a segunda. Tal viés, contudo, apontava para outra questão de suma relevância: a noção de igualdade colocava em prática o rompimento dos laços de fidelidade com o rei. Em Preciso, nota escrita pelo líder José Luís de Mendonça, no dia 10 de março de 1817, em meio ao movimento, o magistrado refletia sobre as razões da queda do governo provincial: "Depois de tanto abusar da nossa paciência por um sistema de administração combinado acinte para sustentar as vaidades de uma corte insolente sobre toda a sorte de opressão de nossos legítimos direitos, restava caluniar agora a nossa honra com o negro labéu de traidores, aos nossos mesmos amigos, parentes e compatriotas naturais de Portugal; e era esta por ventura, a derradeira peça que faltava de se pôr à maquina política do insidioso governo extinto de Pernambuco". Ao relatar todos os acontecimentos ocorridos entre os dias 5 e 10 de março, Mendonça encerrava o escrito felicitando a nova pátria, os patriotas e exaltando, por fim, que acabasse "para sempre a tirania real". Já no poder, os insurgentes conquistaram o apoio das províncias de Paraíba e Rio Grande do Norte que, juntamente com Pernambuco, viveriam por mais de setenta dias sob 
um governo provisório que proclamava a independência da região, molamestra do movimento.

A República criava um novo contrato social, cujas representações, inclusive na mudança de tratamento pronominal das pessoas - introduziamse o uso de vós entre todos, o que os "igualava" e muito assustava os proprietários de terras -, apontava para a inauguração de um novo tempo histórico. O significado da bandeira republicana, nesse contexto, foi de grande simbologia.

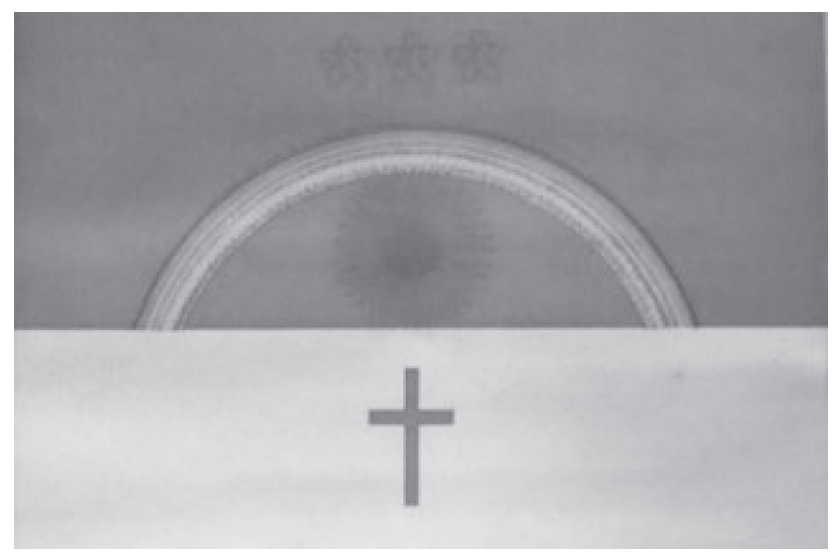

Bandeira da Revolução de 1817

A bandeira "era dividida ao meio, horizontalmente em duas cores, azul e branco. Tinha no branco uma cruz vermelha, sinal da religião cristã, uma alusão ao primeiro nome do Brasil - Terra de Santa Cruz -, e apontava o caminho da redenção", explica a historiadora Iara Lis Schiavinatto (1999: 71). Ainda sobre as cores e significados da bandeira, Schiavinatto ressalta que "na parte azul da bandeira, um sol esplendoroso vinha acompanhado de um arco-íris de três estrelas que simbolizavam as três províncias rebeldes. $\mathrm{O}$ sol significava os habitantes de Pernambuco que sob ele viviam e lembrava a justiça do astro que rege todo o universo" (Schiavinatto, 1999: 72).

O governo central não tardou em reprimir a revolução. As forças do Rio de Janeiro, comandadas por Luiz do Rego, sob a direção do presidente da capitania da Bahia, o Conde dos Arcos, articularam um forte bloqueio naval em Pernambuco. Ao adentrarem em Recife - dominando-a -, os representantes de D. João não hesitaram em ordenar aos homens da tropa real que adentrassem pelos caminhos da política do ferro e fogo. Uma das proclamações das tropas reais exigia que nenhuma reivindicação fosse atendida "sem que preceda como preliminar a entrega dos chefes da revolta, 
ou a certeza de sua morte", sendo, para isso, lícito "atirar-lhes a espingarda como a lobos".

A Revolução, no entanto, perdia força devido a fatores internos e externos que, pouco a pouco, minavam-na. Internamente, elementos conservadores e populares da capitania ajudavam a desmoralizar militarmente o movimento. Segundo as observações de Tollenare, viajante francês que se encontrava na província pernambucana durante a revolução, o povo vivia sem entusiasmo diante do ensaio democrático que se desenhava diante de seus olhos, pois percebia claramente que a sua situação não tinha melhorado como havia anunciado os líderes. Com o passar do tempo, as atitudes das lideranças republicanas passaram a ser questionadas, tanto que Domingos Theotônio já era considerado por muitos um ditador. A perda do idealismo da revolução colocava em cena outra perspectiva: o essencial era a salvação de cada um. Quando houve a entrada de cerca de 8 mil homens realistas em Recife, em 30 de abril, o desânimo já reinava na província. Em 20 de maio, exaltavase a vitória da contrarrevolução. Mais de 6 mil patriotas, contando-se aí escravos e libertos, retiraram-se para Olinda, deixando Recife deserta. Era dado restituir o poder monárquico à província rebelde, sob o comando de Luiz do Rego, novo governador da Pernambuco.

No mês de junho, enquanto Rego reafirmava o contrato soberano com a monarquia portuguesa, através da exposição pela cidade das cabeças e parte dos corpos dos conjurados, como ocorreu no caso da morte do Padre João Ribeiro, muitos súditos reais cumprimentavam o Príncipe Regente nos salões de São Cristóvão, felicitando-o - entre repiques de sinos, iluminações gerais e foguetes - pelo restabelecimento da ordem.

A Revolução Pernambucana foi destaque das notícias da Gazeta do Rio de Janeiro apenas em 14 de maio de 1817, quando as tropas realistas de D. João já estavam à frente do movimento.

Temos demorado por longo tempo a comunicar os nossos leitores quanto nos constava dos desastrosos sucessos, acerca da revolta de Pernambuco, não tanto pelo horror que sentíamos em semelhante acontecimento, ainda que bem desejaríamos não manchar com tal atrocidade as páginas da História Portuguesa, tão distintas pelo testemunho de amor, e respeito que os vassalos desta nação consagrarão ao seu Soberano nas ocasiões de maior apuro, e em distâncias muito remotas; mas para não adiantar fato, ou circunstância alguma em coisa por sua natureza tão odiosa de que não tivemos completa informação; e porque demais estando convencidos, assim como todos, de que os habitantes de Pernambuco, não podiam ter-se alienado até o ponto de perderem os sentimentos de fidelidade e obediência, que noutro tempo realçarão o seu caráter, não acertávamos, como pôde verificar a escandalosa ingratidão, que acabavam de manifestar. As notícias mais individuais, que 
ultimamente têm chegado, nos tiram desta incerteza, mostrando que na funesta rebelião de Pernambuco não teve parte a maioridade de seus habitantes; e não nos arrependemos por isso de uma demora que serviu para confirmar a persuasão em que estávamos e que tínhamos tanto a peito: sabe-se já com toda a evidência, que foi unicamente o resultado da trama de alguns malvados, que tomarão este expediente, para fugir à justa punição de seus crimes. (Gazeta do Rio de Janeiro, 1817, N. $^{\circ} 39$ ).

Paralelamente, em Lisboa, ocorria a descoberta da conspiração militar Gomes Freire contra a Dinastia de Bragança que fora abortada no mês de abril, antes mesmo de sua conflagração. A revolta tinha como objetivo a derrubada da supremacia militar inglesa sob o comando do Marechal Beresford e a implantação de uma monarquia constitucional que, na prática, desejava a restituição da figura real através de um Rei presente, justo e identificado com os anseios do seu povo, uma vez que D. João já era considerado por muitos "o mais perverso, e abominável subversor da pátria” (Memória sobre a Conspiração de 1817, vulgarmente chamada A Conspiração Gomes Freire; escrita e publicada por um português, amigo da justiça e da verdade, 1822: 52-53).

Um dos panfletos apreendidos contra o governo sintetizava as insatisfações dos revoltosos, que desejavam afastar os oficiais ingleses do poder e reorganizar a administração do Estado e das tropas portuguesas. Assim, conspiravam:

\section{Espírito Nacional}

Quem perde Portugal? O Marechal

Quem sanciona as Leis? O Rei

Quem são os executores? Os Governadores

Para o Marechal: hum punhal

Para o Rei: a Lei

Para os Governadores: os executores.

(Fonte: ANTT. Casa Forte. Ministério dos Negócios Eclesiásticos e da Justiça, M.22, fl. 204).

Beresford e os governadores do Reino exigiram a prisão dos revoltosos, abriram processo contra os envolvidos e enforcaram onze dos acusados, entre eles o general Gomes Freire de Andrade, considerado o líder do movimento.

Embora os movimentos ocorridos em 1817 contra o regime absolutista português vivenciassem universos e ideais políticos distintos entre si, em ambos se destacou a forte participação da Maçonaria, um fator preponderante e de grande importância na organização e desenrolar dos eventos políticos contestatórios que muito incomodavam o poder central. Porém, por mais 
que a monarquia luso-brasileira tivesse saído vitoriosa nos dois movimentos que contestavam o poder real, a partir de 1817 , ficava patente a crise do antigo regime português em ambos os lados do Atlântico que, três anos mais tarde, escancararia seus conflitos de forma irreversível, a partir de agosto de 1820, com a Revolução do Porto. A situação era tão delicada que escritos literários de vassalos de renome - como Estanislau Vieira Cardozo, segundo escriturário do Banco do Brasil e secretário do $1^{\circ}$ Regimento de Cavalaria de Milícias da Corte -, circularam pela cidade como uma forma de demonstração de fidelidade ao monarca.

Mas não te penes, Príncipe! Um momento

De perfídia, e desdouro não faz vulto

No quociente do século de glória.

Troveja o claro céu; benigno é sempre.

Cumpre porém olhar atento a esfera:

São das exalações os raios prole.

Enunciada esta insólita ousadia,

Tua alma nobre por extremo aflita,

Mais pelo que urge o nacional decoro

Que pelo que é de ti, que em fim és grande

Há de nadar de júbilo em torrentes,

Quando à porfia em turmas acorrerem

Povos fiéis ingênuos a oferecer-te

Os mais prezados bens - fortunas - vidas.

A ACLAMAÇão DE D. JoÃo VI (1818)

$\mathrm{O}$ ano de 1818 se mostraria bem diferente do anterior. Apesar de envolto em nuvens que desenhavam uma complexa situação política, o fato é que pela primeira vez na história do Velho Mundo um Rei era aclamado na América. A festa de aclamação de D. João VI, ocorrida no dia 6 de fevereiro, na Corte, foi uma das mais importantes manifestações do poder real no período joanino. Tratava-se de um momento sui generis marcado por simbologias e conexões políticas cuidadosamente arquitetadas pela elite luso-brasileira, cuja meta política era a consolidação de um Império luso-brasileiro com sede na América.

A cerimônia foi concebida como um espaço de legitimação do poder real que renovava a relação entre o Rei e seus súditos. $\mathrm{O}$ alcance da adesão maciça de todas as camadas da sociedade era um fator de fundamental relevância, sobretudo depois de a monarquia ter vivenciado momentos de 
grande fragilidade política em decorrência dos movimentos revolucionários de 1817. Dia 10 de fevereiro, quatro dias depois das festividades públicas, o redator da Gazeta Manuel Ferreira de Araújo Guimarães produzia o discurso da folha oficial com o objetivo de fixar a imagem de um povo que abençoa, apoia e adora o seu rei, irrestritamente. "Então salvaram as fortalezas e os navios surtos nesse porto, e se elevaram muitos fogos de artifícios, que arremedavam um regular fogo rolante com perto de dois mil tiros. Foi nesse afortunado momento que o imenso concurso de povo, que estava em frente à Varanda, e que atulhava as ruas contíguas, rompeu em unânimes vivas, que mostravam da maneira mais evidente o prazer que transbordavam no coração de todos."

As celebrações começaram às 9 horas da manhã, com todas as pompas dignas de uma festa da realeza. Os tiros de canhões e os repiques dos sinos indicavam a importância da data. "Toda a família real estava resplandecente de diamantes e de todas as vestimentas da Corte eram notáveis pela riqueza e elegância", observava o pintor e viajante francês J. B. Debret, ao acompanhar a chegada dos membros reais à missa solene, na Capela Real, que selava a magnitude do evento digno das circunstâncias, segundo o francês, pela eloquência política e religiosa (Debret, 1989: 65).

A questão central da aclamação, no entanto, estava intimamente associada a dois fatos políticos de suma importância para a manutenção da integridade da monarquia luso-brasileira. No que se refere à elevação do Brasil a Reino, consumada em dezembro de 1815, o festejo visava reafirmar a autonomia do Brasil dentro do Império Português, assim como imortalizar a figura de D. João VI como o monarca responsável por trazer a prosperidade e a civilização ao vasto continente do Brasil.

A escolha do dia 6 de fevereiro como data que oficializava sua coroação também foi um aspecto particularmente arquitetado por D. João. A associação com a fundação do Reino de Portugal rememorava as antigas tradições enraizadas em torno do princípio que legitimava a autoridade do direito divino dos reis em contraposição à concepção de soberania popular defendida pelos revolucionários na sedição pernambucana de 1817. Na prática, portanto, para além de a data da cerimônia se tornar uma resposta aos princípios republicanos dos revolucionários, ainda perpetuaria no calendário monárquico uma versão vitoriosa da história que solapava a visão dos "vencidos".

A festa de aclamação foi maciçamente financiada pelos negociantes de grosso trato como Fernando Carneiro Leão, Amaro Velho da Silva, Francisco José Guimarães, Francisco Pereira de Mesquita, João Rodrigues Pereira de Almeida entre outros. O grande dinheiro despendido nos festejos tinha como estratégia enaltecer a figura do rei, para assim, consolidarem suas órbitas de 
influência junto a D. João VI. Um dos arcos construídos - o arco do triunfo - realçava a imagem de um Rei ilustrado, cujo projeto era proteger e avançar as atividades comerciais e artísticas do Brasil, agora elevado a uma porção fundamental e civilizada do Império. Luís Gonçalves dos Santos, o Padre Perereca, descreveu com riqueza de detalhes as comemorações em torno da cidade, que toda iluminada, celebrava a coroação pelas igrejas, conventos e casas todas iluminadas cujas chamas e fogos de artifício demonstravam o amor e o prazer de seus fiéis vassalos (Santos, 1825: 632).

As luminárias e iluminações construídas por numerosos personagens endinheirados da cidade davam as diversas nuanças do regozijo que marcava o momento. O comendador Luís de Sousa Dias mandou construir um arco na porta da Alfândega que registrava a imagem da elevação do Brasil a Reino. Já a iluminação feita pelo tenente general José d'Oliveira Barbosa reafirmava o poder divino do Rei com os dizeres “Deus e o meu Rei”. Porém, as manifestações de apoio e fidelidade a D. João não chegavam apenas da parcela mais rica da sociedade. Bernardo Avelino Ferreira de Souza, um contemporâneo dos fatos, afirma que os mais pobres que viviam nos subúrbios também realizavam suas comemorações de acordo com suas possibilidades.

Apesar de tantas solenidades durante os três dias em que duraram os festejos, nem tudo foram flores. Quase um ano depois das sedições ocorridas em 1817, D. João ainda desconfiava da audácia das classes médias e populares, colocando em dúvida a lealdade de seu povo. "No primeiro e no segundo arco, onde eu me achava quase rente dele [D. João], pareceram-me provir de vagas suspeitas originadas de maus dizeres, que continuamente se estiveram a segredar em seu ouvido. Tive uma semelhante oportunidade de o observar, cerca de meia hora antes de seu início da cerimônia", comentava o viajante inglês John Luccock. O contato de Luccock com as classes médias e populares, no entanto, convencia-o de que não havia a menor razão para o temor, já que estava convicto "de que nunca houvera capital mais afeiçoada do que o Rio de Janeiro deste tempo" (Luccock, 1942: 379).

Para garantir a segurança pessoal do monarca e do cerimonial, a Intendência da Polícia distribuiu os soldados reais pela cidade. Munidos de cartuchos de pólvora, muitos deles se infiltravam em meio à gente miúda $\mathrm{e}$ cercavam o palácio para evitar possíveis badernas. Na multidão também foram implantados espiões para vigiarem os "elementos suspeitos" que poderiam atentar contra a vida do Rei. O olhar privilegiado e crítico de Luccock destacava os meios repressivos com que as tropas reais se precaviam diante do povo e, sobretudo, contra os estrangeiros. "Não era permitido a ninguém falar língua estrangeira em meio do povo. No momento em que um senhor natural de 
Veneza se dirigiu a mim em inglês, um soldado lhe ordenou rudemente que falasse português ou calasse a boca" (Luccock, 1942: 379).

A grande participação popular nessa festividade tão marcante não escondia as normas e etiquetas vigentes na sociedade de corte, há séculos enraizada e perpetuada pela monarquia portuguesa em datas comemorativas. O início da aclamação se dava com a entrada do Rei e seus acompanhantes que assistiam a uma oração pronunciada por um eclesiástico, responsável pela explicação dos motivos da realização da cerimônia. Na sequência, o Rei fazia seu juramento perante os dignitários, considerados testemunhas do ato, seguido pelo juramento dos presentes e, posteriormente, realizavase o beija-mão do soberano.

Todo esse cerimonial era regido por uma ordem hierarquia de acesso ao monarca. Primeiro, tinham vez os maiores representantes da nobreza portuguesa, em seguida tinham espaço os procuradores das cidades e vilas - sempre determinados por graus de importância - e, por último, era a vez do clero que, diferentemente dos demais estamentos, não tinha o privilégio de tomar a mão do Rei entre as suas; o que delineava os graus de influências e consequências políticas.

A aclamação popular, por outro lado, também marcava um momento importantíssimo da celebração. Era a ocasião em que acontecia a ovação dos súditos do Rei que, amontoados no Terreiro do Paço, legitimavam os laços políticos existentes entre o povo e o soberano. Logo após, o monarca e a Corte seguiam para a Capela Real, saudando o povo como exigia a tradição. Finalmente, às quatro horas da tarde, era chegada a hora da majestade aparecer publicamente pela primeira vez para os seus vassalos em todo o seu esplendor real.

Os lugares e hierarquias tanto dos súditos ao redor de El Rei quanto das instituições em destaque - como o senado da Câmara do Rio de Janeiro e os representantes da Universidade de Coimbra -, estavam bem delimitados e demonstrava a influência de cada um dos atores sociais nesse jogo de poder permeado por inúmeras representações e construção da memória coletiva.

Enquanto no Rio de Janeiro as iluminações pela cidade durante os festejos da aclamação demonstravam as manifestações de adesão do "povo" ao Rei e ao seu projeto político, em Portugal o silêncio, a indiferença ou as ausências nos festejos marcavam a revolta e a resistência ao mesmo momento. Houve até destruição de luminárias. Segundo o relato do português José Ribeiro Pinto, em Lisboa não se ouvia os vivas quando foi mostrado o retrato de D. João VI. 
Revolução do Porto e a volta da Família Real para PORTUGAL

Ao final de 1820, era traduzido na Bahia um folheto anônimo em francês cuja autoria foi atribuída a Cailhé de Geine, informante da intendência da polícia baiana, Intitulado Le Rói et la Famille Royale de Bragance DoiventIls, dans lês Circonstances Presentes, Saourner à Portugal, ou Bien Resterau Brésil? O tema do folheto colocava em cena uma polêmica que extrapolava o universo particular das discussões dos ministros de D. João VI desde 1814. O Rei e a família real deveriam ficar no Brasil ou voltar para Portugal?

$\mathrm{O}$ folheto teve grande impacto na Corte, onde gerou importantes discussões, uma vez que defendia a permanência definitiva da Corte no Brasil, a construção de um Império Brasileiro e o abandono de Portugal, em uma clara reação às consequências advindas da Revolução do Porto. Entre as reivindicações dos revolucionários, existia uma proposta que defendia a preservação do Antigo Regime no Brasil ou, em outras palavras, propugnava a manutenção do status de Colônia deste lado do Atlântico.

A reação a essas ideias foi de tal envergadura que as autoridades reais apreenderam os exemplares em circulação. Porém, por mais que o Brasil ainda vivesse sob um aparato censor, que estruturava um dos alicerces do poder real, tal fato já apontava para uma nova realidade: dava-se início à discussão pública de temas políticos verdadeiramente relevantes para o destino da Nação, em que a pluralidade de opiniões se tornava a tônica principal do debate. "Ao contrário do que pretendia o autor, o escrito ampliou o desejo dos luso-brasileiros de agir em uníssono com os constitucionalistas de além-mar", relata a historiadora Lúcia das Neves (2008: 97).

Surgiam as mais diversas formas de julgamento sobre o tema, sobretudo diante de uma proposta tão radical. A ideia de separação entre Brasil e Portugal estava longe de ser um consenso entre a elite luso-brasileira. O conflito político, no entanto, chegava ao seu limite: em agosto de 1820 eclodia na cidade do Porto uma revolução liberal que defendia a bandeira de uma monarquia constitucional. As notícias desse fato político, no entanto, só seriam oficialmente noticiadas no Brasil em novembro do mesmo ano. 
Em 9 de novembro de 1820, a Impressão Régia publicava uma edição extraordinária da Gazeta do Rio de Janeiro. Naquela quinta-feira, a sociedade carioca soube oficialmente sobre a Revolução do Porto - um movimento político liberal - que desde 24 de agosto mantinha a sociedade portuguesa sob constante tensão e conflitos de interesses. No Porto, os revolucionários defendiam uma bandeira patriótica: proclamar a liberdade e a independência nacional, através da necessária Regeneração que, por essa ótica, seria responsável pelo término dos males pretéritos. Porém, a regeneração não foi interpretada pelas elites ilustradas e revolucionárias portuguesas como uma ruptura radical com o passado monárquico, mas como um resgate do "constitucionalismo da monarquia lusitana que se opunha à ideia de um Estado absolutista superdimensionado em suas funções e visto como responsáveis pelos males que assolavam o país" (Silva, 2000: 285). Agora era a existência de uma Constituição, uma lei fundamental, que passaria a assegurar ao povo os laços tradicionais existentes entre eles e o Rei soberano.

As notícias da Revolução chegaram ao Rio cerca de quarenta dias depois e se propagaram como rastilho de pólvora pelas ruas da cidade. A questão, porém, é que esse fato histórico de tamanha relevância para a sustentação do Império luso-brasileiro não parecia ser uma novidade para a elite econômica e política da Corte. Segundo atestava uma folha inglesa traduzida e publicada no Correio do Porto, no dia 20 de outubro, os brasileiros já estavam informados sobre o andamento de um projeto revolucionário em Portugal. "O Brasil está muito inquieto, não sendo improvável que a Revolução de Portugal se estenda além do Atlântico. Cartas da Bahia, Pernambuco, e outras terras do norte do Brasil, escritas por pessoas mui respeitáveis exprimem receios de próximos rompimentos; e até dão a entender que o Projeto de uma Revolução em Portugal era conhecida no Brasil já em Junho passado", informava o periódico.

Como era de se esperar de um súdito fiel de D. João, o então redator da Gazeta, Manuel Ferreira de Araújo Guimarães, anunciava as notícias de modo a enaltecer a monarquia e execrar a figura dos revoltosos. Dizia ele:

O espírito de inquietação e o desatinado desvario, que tem atacado o meio dia da Europa, desgraçadamente soprou sobre uma das mais belas cidades de Portugal, e corrompendo ânimos ambiciosos, e indiscretamente amigos da novidade, causou tumultos efêmeros, que a prudência do Governo se apressou a atalhar e a extinguir. Para darmos aos nossos Leitores uma ideia deste abominável acontecimento, basta copiarmos a seguinte PROCLAMAÇÃO. 
Publicado na seção Rio de Janeiro, o comentário de Guimarães antecedia a inserção de documentos oficiais sobre os acontecimentos ocorridos na cidade do Porto, entre os idos de agosto e setembro. Todas as notícias divulgadas nesse número extraordinário eram extraídas da Gazeta de Lisboa e, curiosamente, limitavam-se ao que fora publicado no periódico lusitano até, precisamente, o dia 2 de setembro de 1820 . Acontece que, desde o dia 5 de setembro, os governadores do Reino enviavam ao Rio as primeiras cartas de ofícios de portugueses e os seus próprios documentos, informando o Rei acerca das providências tomadas pela Regência de Lisboa que, para apaziguar a situação, decidira convocar as Cortes.

Realmente, até o início de setembro, os governadores do Reino lutaram contra a evolução do movimento com as armas que tinham nas mãos: a diplomacia, a força das palavras no universo público e a organização de um corpo militar, responsável por combater os revolucionários do Porto. Em 30 de agosto, o redator da Gazeta de Lisboa considerava o levante um "horrendo crime de rebelião contra o poder, a autoridade legítima do nosso Augusto Soberano, EL-REI Nosso Senhor", cujas atitudes eram frutos de "alguns poucos indivíduos mal intencionados [que] alucinando os chefes dos corpos das tropas daquela cidade; poderão desgraçadamente influí-los" e, assim, romper o juramento de fidelidade ao monarca, já que se atreviam "a constituir por sua própria autoridade naquela cidade um governo a que dão o título de Governo Supremo do Reino", cuja bandeira defendia a monarquia constitucional. 


\section{Num. 205.

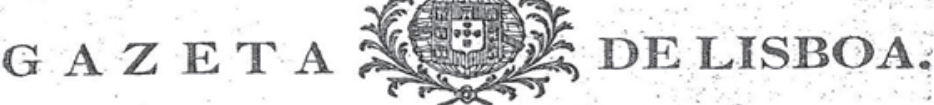

COM PRIVILEGIO DE SUA MAGESTADE.

QUARTA FEIRA 30. DE AGOSTO.

LISBOA 29 de Agosto.

P R O C L A M A C . I O.

7 Dortuguezes! O horrendo crime de rebellião contra o poder, $\mathbf{e}$ Au1 thoridade legitima do nosso Augusto Soberano, ElRei Nosso Senhor, acaba de ser commettido na Cidade do Porto.

Alguns poucos Individuos mal-intencionados, allucinando: os Chefes dos Corpos da Tropa daquella Cidade, pudérăo desgraçadainente influillos paraque, cobrindo-se de opprobrio, quebrassem no dia 24 do corrente o juramento de fidelidade ao seu Rei, és suas Bandeiras, e se atrevessem a constituir, por sua propria Authoridade, naquella Cidade hum Governo a que dăo o titulo de Governo Supremo do Reino. Bem conhecião os perversos, que maquinárão esta conspiração, que só poderião conseguir extraviar coraçőes Portuguezes occultando-lhes, debaixo de apparencias de hum juramento illusorio de amor e fideli2 dade ao sen Soberano, o primeiro, e tremendo passo que thes fizerão dar para o abismo das revoluçôes, cujas consequencias podem ser a subversão da Monarquia; e a sujeição de buma Nação sempre zelosa da sua independencia á ignominia de hum jugo estrangeiro.

Não vos illndais pois, fieis e valorosos Poriuguezes, com semelbantes apparencias : be evidente a contradição com que os revoltosos', protestando obediencia a ElRei Nosso Senhor, se subtrahem:á Authoridade do Governo legitimamente estabelecido por Sua Magestade-, propondo-se, como declarão os intrusos, que a si mesmos se canstituírão debaixo do titulo de Governo Supremo do Reino, a convocar Côrtes, que sempre serão illegaes, quando não forem chamadas pelo. Soberaвo; e a annuciar mudinças, e alterações, que, quando muito; devião limitar-se a pedir, por isso gue só podem emanar legitima', é permanentemente do Real consentimento.

Gazeta de Lisboa, 30/08/1820, $N^{\circ}$ 205. Nessa edição da gazeta oficial, a sociedade lisbonense tomava conhecimento dos fatos ocorridos na cidade do Porto, seis dias antes.

Toda essa problemática vivenciada pelos acontecimentos da Revolução do Porto era resultado de uma conjuntura histórica que permeava a vida política luso-brasileira desde 1815, quando o Brasil fora elevado a Reino Unido de Portugal e Algarves. A conjuntura política era deveras delicada, quase insustentável. Assim, em 15 de setembro, os mesmos governadores que até então defendiam "acirradamente" a manutenção da ordem monárquica absolutista da Dinastia de Bragança sob a chefia de D. João VI formaram uma junta governativa - um governo interino -, acataram as exigências dos "rebelados", ao convocarem as antigas Cortes e assumiram uma nova postura política diante dos fatos e, consequentemente, do próprio Rei. A ausência do monarca acentuava a urgência de medidas que contivessem a situação, corroborando para que os líderes políticos se sentissem aptos e 
livres para dirigirem os destinos do Reino. Nessa data, mudava-se, inclusive, o discurso da Gazeta de Lisboa, que passava a defender o desejo de "toda a nação". "Chegou o momento de sufocar, pela unanimidade de votos da Nação, o gérmen de civis discórdias; já são livres de acanhados terrores as vozes dos Portugueses; conseguiu-se enfim uma justa e moderada liberdade neste dia, duas vezes memorável", refletia o jornalista.

Havia aqueles que criticavam as qualificações dos autores da Revolução do Porto, que eram considerados abomináveis e escandalosos, jamais rebeldes e sediciosos. Por outro lado, também tinham os que já se denominavam brasileiros, apoiavam a separação e defendiam a independência como forma de corrigir os vícios do governo do Brasil, pois era um engano esperar qualquer melhoria advinda do trono. A força do folheto anônimo de fins de 1820 foi tão ampla que a própria Gazeta do Rio Janeiro, em 31 de julho de 1821, anunciava a sua venda "devidamente" analisada. "Na loja da Gazeta se acha vertido em Português e analisado o folheto francês que há tempos se espalhou no Rio de Janeiro, que tinha por título O Rei e a Família real devem nas circunstancias presentes voltar para Portugal ou ficar no Brasil, por 960 réis", informava o anúncio. Contudo, quando a direção da Gazeta decidiu dar publicidade ao impresso, D. João VI e toda a corte já havia retornado para Portugal, assim como as discussões pela definição dos padrões de uma monarquia constitucional já ganhavam acirrados debates nas Cortes de Lisboa.

Em 2 de janeiro de 1821, Cailhé de Geine enviava uma carta a Paulo Fernandes Viana, intendente da polícia no Rio. Neste escrito, relatava o novo caminhar da população baiana depois do conhecimento da Revolução do Porto: as fermentações dos ânimos apareciam de forma mais explícita no universo público. Ninguém mais parecia se preocupar em esconder suas opiniões, revelando-as através da produção de papéis e canções patrióticas que passavam a circular livremente, sendo lidos ou cantados em voz alta pelas ruas (Cartas de C. de Geine ao Intendente da Polícia. BNRJ. Mss. II-33, 22,54. 2 de janeiro 1821).

Essa nova conformação política e suas consequências no cotidiano da sociedade luso-brasileira, mas principalmente da sociedade carioca, aparecem com maior nitidez a partir do raiar do ano de 1821. O final do ano de 1820, entretanto, já sinalizava algumas transformações. Em 19 de dezembro, a sociedade portuguesa era informada pela Gazeta de Lisboa sobre as decisões reais de D. João VI deste lado do Atlântico. O monarca autorizava as Cortes convocadas pelos precedentes Governadores do Reino, reclamando, no entanto, o fato de a convocação ter ocorrido sem o concurso da sua Real Pessoa, o que considerava, particularmente, injusto. A mesma edição também anunciava que logo em breve - assim que concluídas as mesmas Cortes, e sendo remetidas as propostas delas para serem legalizadas com a régia 
sanção - os portugueses teriam no meio de si a real figura de D. João ou a de algum de seus augustos filhos.

Já por essa época, muitas das exigências vigentes na Revolução do Porto apareciam de forma mais nítida nas Cortes, como foi o caso do debate sobre as leis que pautariam a liberdade de imprensa e o fim definitivo da censura régia. Entre os temas de grande relevância para a Constituição, a regulamentação da liberdade de imprensa compôs uma das mais acaloradas discussões entre os deputados. A questão foi de tamanha urgência que, em 5 de fevereiro de 1821, Soares Franco - ex-redator da Gazeta de Lisboa no período das Guerras Napoleônicas - apresentava um projeto de decreto sobre liberdade de imprensa extraído em grande parte do regulamento espanhol. A própria noção de imprensa era reestruturada pelo governo interino do Reino, em Lisboa, que determinava: "do primeiro de janeiro do ano próximo de 1821 , por diante, a Impressão Régia se denomine = Imprensa Nacional = por ser esta uma propriedade da nação" (ANTT, Ministério do Reino, Livro 325: 39), ${ }^{1}$ fato que impulsionava a mudanças do título e concepção do jornal, que passaria a ser denominado Diário do Governo.

Se a maioria da sociedade portuguesa defendia de forma veemente um novo sistema de governo baseado na monarquia constitucional, havia também vozes dissonantes que criticavam a ideia de uma Constituição. Um folheto traduzido do espanhol que circulou por Lisboa, entre os idos de 1820 e 1821, fazia a seguinte reflexão:

Com que já temos constituição? Que escândalo! Que Horror! Que desaforo! Quem havia de pensar que ao fim de tantos anos que estão trabalhando os homens mais doutos mais respeitáveis para desterrar semelhante nome dentre nós, havia chegar um dia em que não só se ouvisse sem estremecer-nos, senão que se proclamasse, se exaltasse e ainda, para assim explicar-me se divinizasse? Em que tempo vivemos, Sr. d. Fernando, e que desgraça há sido a nossa ter alcançado este maldito século XIX. ${ }^{2}$

A verdade era que o raiar do século XIX trazia consigo um legado fundamental da Revolução Francesa: a discussão de temas políticos na arena pública pelos homens comuns. Isto é, se dessacralizava a política, tornando-a um tema a ser resolvido por toda a Nação. Nas palavras do historiador João Luís Lisboa, o início do século XIX marca a "altura dos grandes debates sobre as virtualidades da intervenção do homem na modificação e na condução

\footnotetext{
1 Documento direcionado à Joaquim Antonio Xavier A. da Costa, assinado por Manoel Fernandez Thomaz, importante dirigente do governo interino.

2 Lisboa. Punhal dos Corcundas. n. ${ }^{5}$, p. 41 . Lamentos políticos de um pobrezinho e preguiçoso que estava acostumado a manter-se à custa alheia, por O lamentador.
} 
da coisa pública" (Lisboa, 1991: 164), particularmente no contexto português, já que o Rei e sua Corte estavam a milhares de léguas de Lisboa, antigo centro do poder.

Sob essa nova perspectiva, a evolução e, posteriormente, a repercussão da Revolução do Porto nos dois lados do Atlântico impôs uma nova cultura política que se delinearia ao longo de 1821 e 1822, criando também o nascimento de um novo vocabulário político entre os homens ilustrados que pensavam os destinos do império. A "cultura política de uma sociedade compõe-se não só de conhecimentos e crenças que fundamentam as práticas possíveis no interior de um sistema político, como as normas estabelecidas para definir os direitos e deveres dos participantes como cidadãos", o que na prática, delimitava "as fronteiras das comunidades a que pertencem indivíduos e grupos, legitimando ou desqualificando as suas reivindicações", define a historiadora Lúcia Neves (2003: 25-26).

Se no início de 1821 a vigência das Cortes em Portugal já demarcava vieses importantes da monarquia constitucional a ser instituída no Império Português, no Brasil ainda se desenhavam as primeiras adesões às Cortes e à Constituição, cujo impacto e repercussão se deram de forma diferenciada em todo o Brasil, tão caracterizado pelas especificidades regionais. O Pará aderia ao projeto constitucional $\mathrm{em} 1^{\circ}$ de Janeiro de 1821, seguido do Maranhão e do Piauí. Em 10 de fevereiro, era a vez da Bahia e, em seguida, de Pernambuco. Nessas províncias, particularmente, o movimento constitucionalista foi "em grande parte resultado da ação de brasileiros libertos da revolução de 1817, cujos ânimos conseguiram ser totalmente sufocados pelos esforços dos respectivos governadores locais", afirma a historiadora Ana Rosa C. da Silva (2000: 292-293).

Apesar de as províncias do norte e nordeste terem concordado prontamente com o sistema constitucional, não houve uma perfeita sintonia nas tendências e motivações dessas províncias; pelo contrário, desde o início, a agitação pelo controle da situação se mostrava aguda. Todas essas capitanias, porém, convergiam em um ponto importante: faziam oposição ao despotismo do Rio de Janeiro, diferentemente das províncias do sul e sudeste, que assumiram um tom mais controlado.

Já no Rio de Janeiro, a particularidade dessas transformações aparecia desde 1820, quando a cena política brasileira já contava com o surgimento de novos protagonistas que, em 1821, seriam líderes de um importante movimento político em prol do juramento da constituição de Lisboa, ocorrido no largo do Rossio. Esse novo grupo era composto por proprietários de terras e comerciantes do Recôncavo da Guanabara e do Campo dos Goytacazes que se aliaram aos negociantes de gêneros de abastecimento e varejistas, além de bacharéis e militares, com o intuito de se contraporem aos interesses das 
famílias portuguesas e negociantes de grosso trato, ambos articuladores das esferas de decisão do Estado.

Denominado de liberais, seus principais representantes - Joaquim Gonçalves Ledo, Januário da Cunha Barbosa, José Clemente Pereira, Luis Pereira da Nóbrega de Souza Coutinho e Manoel dos Santos Portugal - eram homens que buscavam o enriquecimento e a ascensão na esfera pública, marcadamente por defenderem interesses antagônicos aos da alta burocracia portuguesa, representada pela nobreza emigrada, os comerciantes de grosso trato, como a família Carneiro Leão, e os ministros de Estado, entre eles Silvestre Pinheiro Ferreira e Vilanova Portugal.

26 DE FEVEREIRO DE 1821

O grupo dos liberais liderou uma das mais importantes manifestações políticas ocorridas no espaço público durante a governação de D. João VI. A parada militar ocorrida em 26 de fevereiro de 1821, no largo do Rossio na capital, exigia o juramento do Rei à Constituição de Lisboa e a substituição dos ministros de Estado e das pessoas que ocupavam os principais cargos políticos no governo. Eram favoráveis à volta de D. João VI para Portugal, sob a perspectiva de uma monarquia constitucional, com sede em Lisboa. Paralelamente a essas reivindicações, as atitudes do regente escancaravam a forte crise pela qual passava a monarquia portuguesa, cujo impasse era sinalizado para toda a sociedade fluminense inclusive com importantes contornos na imprensa.

Em 18 de fevereiro, D. João VI determinava a volta de D. Pedro a Portugal com o objetivo de "assegurar a felicidade da nação" e, assim, "restabelecer a tranquilidade geral daquele Reino; para ouvir as representações e queixas dos povos" (Gazeta Extraordinária do Rio de Janeiro, 1821, No 3). ${ }^{3}$ No dia 24, a Gazeta do Rio de Janeiro notificava em publicação extraordinária o decreto real que enviava o Príncipe Real ao Reino para consolidar a constituição portuguesa.

3 Na publicação do periódico a assinatura do Regente datava de 22 de fevereiro de 1821, folha 132 do Livro $8^{\circ}$. 
N.・ 3.

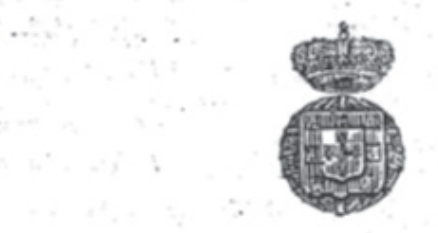

Anno 1821.

\section{GAZETA EXTRAORDINARIA \\ Do \\ RIO DE JA N EIRO.}

SABBADO \&4 DE FEVEREIRO.

Destrias. . vie genenct insitem :

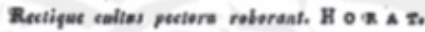

RIO DE' JANEIRO.

\section{E C R E T O.}

$\mathbf{E}$

Xigindo as circunstancias em que se acha a Monarchia justas e adequadas providencias pa. ra consolidar o Throno, e ansegurar a felicide. de da Naçio Partururza, Renolvi Dar a unaior prova do constante desvello, que $\mathrm{Me}$ anima pefo bem dos Meus Vassallos, Determinando que - Meu muito Amado e Prezado Filho, D, PE. pro, Principe Real do Reino Unido de Portu. gal, Braxil e Algarves, va a Portugal nunido da Authoridade e Instruç̧̋́es necessarias, para pôr logo em execuçín as medidas e providencias que Jolgo convenientes, a fim de restabelecer a tranquillidade geral.daquolle Reino; para ouvir as representaçốes e queixas dos $\mathrm{Po}$. vos; - para entabelecer as refórmas e melho. ramentos, e as Leis que possío consolidar a Constituiçio Portugerza ; e tendo sempre por base a justiça e o bem da Monarehia, procurar a eatabelidade e prosperidade do Reino Uni. do ; devendo ser-Me transidittida pelo Principe Real a mo-ma Constituiçio, a fim de receber, sendo por Min Approvada, a Minha Real San. ç̧ăo. Nio podendo porém a Conatíniçäo que em consequencia dos mencionados Poderes se - ha de estabelecer e sanccionar para os Reinos de Portegal e Algarver, ser igualmente adapta. vel e conveniente em todos os sens aniges e pontes essenciaes á Povoaşâo, luczlidade e mais circunstancias tifo penderotas ci mo attcndlitis deste Rrines de Bravil, assim cume as das llhas - Dominis.s Ulusmarines, que naso nerrcem menos a Muba Real Centenplacko e P.ternal Cuilates Hei por cunvenis nte Mandar censo. car a-rsia Certe es Precuraderts, que as Camaras des Cidales e Villas principacs, que tem Juizes Letrades, tanto do Reino do Brazil, cumo das Illas des Ageres, Madrira e Calo Verde ciegerem : E Sou outrosim Servido que eilas hajto de os escolher $e$ nomear see demo. $r a$, para que reenides aqui o mais prontamente que for pessivel em Junta de Cortes, com a Presidencia da Pessoa que Eu Hutier por bem escelher para este Lligar, nío sómente examinean e consultem o que dos referidos artigor for adaptavel ao Reino do Brozill, mas tambean $\mathrm{Me}$ proponhajo as mais reflreas, os melheramentos? os estabelecimentos, e quaes. quer outras providencias çue se entenderem es. senciaes ou uteis, on . ja para a seguian;a individual, e das prepriadade, boa administracko da Justica e da Fazenda, angmento do Commercto, da Agricultura, e Navegaço, Estudos e Educaçấo publica, en para outros quacrquer objectos conducentes a prosperidade e bew geral deste Reino, e dos Duaninics da Coroa Parfutoura.

$\mathbf{E}$ para secelerst aues traball.es, e prepa- 
rar as materias de qua deverís occupar-se: Sou tamban Servilo Crear desie já i hum. Comnis. sío co nontas de Pessas resilentes nesta Coirte. e por Mim nomsalas. qua entrarás logzo em exercicio, e continuaras con os Procurabres das Camiras qua se forein apresentanbo, a tratur de tolos os neferilos objectos, para cora ple. no coniscinsoto de caus $\mathrm{E}_{1}$ os Desilir. A Mesi ds D sensarz, do Paç, o tenha assim cotenfih. fagt pablicar e ex-catar, passan lo as Ortagi nacecrios is Cemuras, es mais Des juchn e participaçoss quat precias forems as quast tinban on fart, ass Governos das Pro. Qiacias pelas Secretariat da Estals. Palacio da $R$ ig do. 7atiry en dawiva de Fevereir, de mil

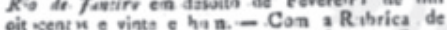
SUA MAG.3TT IOZ. - Enti confor as Pay'

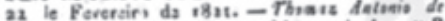

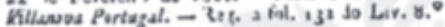

\section{E C R - E T O.}

Tenta Mialifac $\mathrm{C}$ ansas os Pracuratores

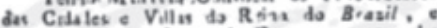
Ithas, pars en Jast de C urtes sa iratar des Dels Cinstiancioases. qua se discutem nas Car. tes da Libos, e dis milhoramzates que forera useis a Brazil. Cresals ha as Con nisslo de Pesias da Mra Crasalho part preparar estes

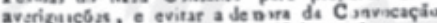

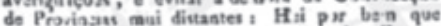
a provinas Comniriso stja compata das Petsoas gue constio da Ralach incluss, assiguth por Forerz Atanis de Villavous Portagal, Ministro e Secretario de Eitado dos Nutacin do Reino e a ella polerí assistir o M sa Procursdor da Curn, e ser chemalo qualquer dus ontros Five caes, oy E narezalor pislicus, qua far can. veaicate, $O$ masm? Minituro e Secretario de E. talo e ten's astim ententify, e tho participe, pata qas, se n depen lencia de o itr, Tiuals, ha. fó de entrar en exercicin. Palucio da Ris de Gaquin en vinte e tres de Ferereirs te nil aitoctatu e vint? e hos. - Co.s a Rabnea de SUA MAGESTADE.

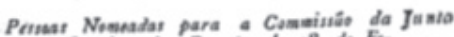
Creada pele Decrete de 18

Para Presidenie.

O-Marģuea de Aligrile.

Para Depulados.

O-Barlo de Santo Ausro.

$\mathrm{M}$ inienhor Alinelía.

Laiz Fout de Carvalho a Mrllo.

Antonio Lais Percira da Casba.

Atsonio Rolriguet Velloso de Olivira.

Job) Sevoriese Maciel da Coula.

Ciaills Miria Tondlet.

7oie te Soase de Mendonga Corte Rralo.

toid da Silva Lingas.

Muriaseo Jase Pereira da Fonsera.

Jilo Relinigues Perrira de Almeida.

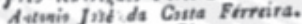

Francisco Xavier-Pires.

Joud Cutaro Gomet.

\section{Procurador da Corsa.}

Jue de Otiocira Botelho Pinto Mospacira.

$$
\text { Secritariot. }
$$

Masel Fucinto Nogurira da Gama.

Masod Girrira de Figweirrde.

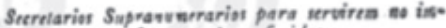
pedimate dos referides.

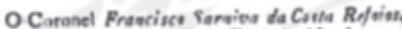
O Dusabargajor Jod, Jud de Mrwdonga.

Palacio do Rio de 7antirn en 23 de Feve. reim de 18 at. - Thomas Antanio de Villasavo Portiegal. 
O discurso real de D. João evidenciava os novos paradigmas que a sociedade como um todo estava compartilhando. Como soberano agora submetido a uma constituição feita e pensada pelo povo, D. João se via na posição de partilhar os poderes da nação, já que era por ela escolhido. A partir de então, o monarca devia obediência às leis que a sociedade legislava e promulgava nas Cortes, sendo reduzido seu espaço de negociação, que ficava sujeito a uma determinação coletiva vinculada aos trâmites do poder legislativo. A volta de D. Pedro para Portugal era uma forma de D. João VI conservar os laços reais nos dois lados do Atlântico para, em última instância, garantir a unidade e legitimidade do Império Português (Schiavinatto, 1999: 96-105). A circunstância era muito complexa, motivo pelo qual, no dia 23 de fevereiro, o Rei dava publicidade à relação dos membros da comissão da "Junta das Cortes" do Reino do Brasil. A ratificação dessa decisão ocorreria no dia seguinte, com a aprovação no Reino do Brasil da Constituição que estava sendo feita em Portugal. Os membros da comissão "eram os mesmos homens que no decorrer do governo joanino haviam acumulado enormes fortunas e se assenhorado da administração pública", afirma a historiadora Cecília Salles Oliveira (1999: 116). Na prática, a presença de personalidades como Tomás Antonio Vilanova Portugal, o Conde de Palmela e o Conde dos Arcos, perpetuava o mesmo poder político e as antigas condições de mercado vigente. Essa conjuntura conflitava diretamente com os interesses dos liberais fluminenses, que buscavam criar instrumentos jurídicos que legitimassem a sua preponderância sobre o mercado e a esfera pública. $\mathrm{O}$ foco da crise monárquica estava nas decisões reais que se passavam dentro do alto escalão governamental, fato que já se delineava pelo universo público de diferentes formas.

Desde a chegada da notícia da Revolução, o Rio presenciava um momento político de efervescência e ebulição. Já em meados de 1821, os habitantes da cidade produziam seus escritos que agora circulavam por todos os cantos em um clima de maior liberdade. Multiplicavam-se os manuscritos - cartas, anotações, papéis públicos - que geravam muitos burburinhos sobre o futuro do Império Português e, obviamente, contribuíam para o raiar de novas reflexões sobre a política real. Essa atividade ganhava tamanha dimensão que os próprios escravos passavam a esquadrinhar uma outra vertente de atuação, impostando suas vozes e opiniões, em uma clara perspectiva de sujeitos históricos agentes (Morel: 2005:232-233).

A manifestação de 26 de fevereiro de 1821 foi resultado dos dias de intenso conflito e tensão que ocorriam na órbita governamental. $\mathrm{O}$ movimento evidenciava o embate de posições políticas entre o governo e um grupo de cidadãos livres insatisfeitos, cujas relações comerciais eram muitas vezes perpassadas por elos de parentesco com os europeus e 
também pelo contato com a maçonaria, que os tornavam mais próximos dos revolucionários vintistas.

D. Pedro se responsabilizou pelas negociações entre os liberais - que exigiam a aprovação da constituição - e a palavra final de D. João VI, que aceitava o novo cenário político. Um contemporâneo dos fatos descreve que, desde o amanhecer do dia 26, quando todo o batalhão militar já se organizava na Praça do Rossio exigindo que o Rei se rendesse às Cortes, apareceu a figura de D. Pedro. Com um papel nas mãos, leu para as tropas que aguardavam a decisão real. "Tudo está feito: a Tropa pode ir a quartéis, e os oficiais vão beijar a mão do meu Augusto Pai" (Relação dos Acontecimentos do Rio de Janeiro no dia 26 de fevereiro de 1821 e algumas circunstâncias que o precederam e o produziram. BNP. Seção de Reservados, Cód. 10.759).

O bacharel Marcelino José Alves Macamboa argumentou que essa atitude não atendia as reivindicações e que o Rei deveria jurar as Cortes.

Em consequência desse momento de conflito, D. Pedro se comprometia em levar as solicitações dos revoltosos para D. João, inclusive com o pedido de afastamento de Paulo Fernandes Viana e Vila Nova Portugal, ambos homens de proeminência no governo. Depois da reunião com o monarca, que consentiu todas as exigências, D. Pedro voltou à praça e leu o decreto real de 24 de fevereiro. Foi ovacionado pela população que, sob vivas, aclamava o nascimento de um novo tempo. Alguns escritos da época exaltavam a relevância da atitude do príncipe, que foi considerado por muitos um herói.

Os Heróis sempre marcam

Um dia com grandes Feitos

Outros além levantaram

Padrões de valor inteiro;

Mas o Rio de Janeiro

Um herói em si achou

Que de mais glória coroou

26 de fevereiro.

(Poesia em aplauso dos heroicos feitos do memorável dia 26 de fevereiro 1821, Rio de Janeiro, Imprensa Régia, 1821).

Às onze horas da manhã, D. João estava in persona no Rossio para reafirmar as palavras e o pacto de lealdade do filho com o seu povo. Ao ser ovacionado, o Rei punha em prática os códigos de sociabilidade tão presentes e necessários nas relações hierárquicas e de subordinação vigentes na monarquia portuguesa: reverenciava o povo com beija-mãos, o que supostamente sinalizava para o restabelecimento da ordem. "D Pedro, ao ocupar a cena pública, sintetizava um modo de agir mais condizente com 
a intenção política liberal, que não reprime a revolta, o descontentamento, mas, ao contrário, sabe remanejá-los a seu favor", elucida a historiadora Iara Lis Schiavinatto (1999: 99). Com essa atitude, conseguia dissimular a derrota do rei, que cedia às exigências do povo.

Já no dia 28, o redator da Gazeta descrevia os fatos ocorridos dois dias antes pela ótica da conciliação entre os envolvidos. Segundo Guimarães, as múltiplas circunstâncias tiveram "vantajosos resultados" que podiam ser vistos através da "geral tranquilidade no meio dos acontecimentos quase sempre rubricados com sangue". No final da reportagem, o jornalista abria um diálogo com os leitores da folha, dizendo que bastava "transmitir uma singela e verdadeira exposição do que houve de mais notável neste dia singular a aqueles, que não tiveram a satisfação de o presenciar."

Era preciso que a Gazeta veiculasse essa versão dos fatos até porque a direção do jornal tinha ciência de que na cidade já circulavam outras informações sobre os acontecimentos advindos de além-mar, que vinham pelas correspondências particulares. Nessa mesma data, a Impressão Régia publicou um Suplemento à Gazeta $\mathrm{N}^{\circ}$ 17, que "complementava" as informações veiculadas na mesma edição. Ao contrário do que poderiam supor os contemporâneos, o jornalista não só defende explicitamente os interesses do povo, como também reverenciou o patriotismo dos revolucionários vintistas. Dizia ele: "Retumbou no Brasil a voz, que alçaram nossos Irmãos em Portugal, e o fogo do nobre patriotismo, acendendo-se nos peitos generosos dos habitantes do Rio de Janeiro, [que] rompeu as prisões que o detinham, e se manifestou com o maior entusiasmo". A participação popular era justificada "pelo desejo de ver melhorada a sua situação, ambicionando a glória de regenerar a Pátria." Ainda segundo o redator, como o povo não podia realizar tal empreitada por si só e "ultimar tão grande obra, convidou a cooperação daqueles que, por mais de uma vez tem salvado, e achou no brio, valor e honra dos mesmos, o auxilio, de que precisava", em referência aos militares, a Tropa e ao grupo dos liberais.

Nessa publicação há um rompimento com o discurso real que glorificava o monarca e sua infinita benevolência para com o seu povo. O gazeteiro assume, inclusive, a existência de condições sociais conflituosas (sobretudo para os menos privilegiados) dentro do sistema absolutista português. Diante de tamanha ousadia, já que tudo isso tinha sido dito em um jornal oficial, é bem razoável que os diretores do periódico estivessem inquietos com as consequências adversas do processo político desde a Revolução do Porto e, por isso mesmo, buscassem uma rearticulação do discurso da folha. 
O ano de 1821 foi, decisivamente, um período de grandes e importantes mudanças na vida sociopolítica e cultural do Brasil. As múltiplas manifestações de ordem pública só cresceriam ao longo do ano, sobretudo depois do movimento constitucionalista de fevereiro. Nesse cenário, os cafés e as livrarias se tornavam locais privilegiados das discussões políticas, apesar de o absolutismo não ser ainda uma página virada da história luso-brasileira. "Diante do poder Absolutista, havia um público letrado que, fazendo uso público da Razão, construía leis morais, abstratas e gerais, que se tornavam uma fonte de crítica do poder e de consolidação de uma nova legitimidade política", afirma o historiador Marco Morel (2005: 201).

O mês de março marcaria importantes contornos nessas transformações que, em âmbito mais amplo, estavam imersas nas novas problemáticas vigentes no Império luso-brasileiro. Nesse mês, surgiam três jornais no Rio - uma absoluta novidade -, já que até então todo papel impresso que circulasse pela cidade (incluindo-se aí a imprensa) era de domínio privado do governo, através da Impressão Régia e, portanto, necessitava de uma licença real para circular.

O amigo do Rei e da Nação, de Ovídio Saraiva de Carvalho e Silva, foi um periódico que circulou entre os meses de março e junho de 1821 . O texto era escrito em forma de artigo, sendo publicado em três partes. Para além deste, nascia também $O$ Bem da Ordem e O Conciliador do Reino Unido. Enquanto o primeiro tinha como redator o cônego Francisco Vieira Goulart, o segundo foi dirigido por José da Silva Lisboa, o visconde de Cairu, todos eles homens ilustrados pertencentes a um estrito círculo cultural diretamente ligado à realeza. Diferentemente de $O$ amigo do Rei e da Nação, O Bem da Ordem foi uma coleção de dez edições, escrita em formato editorial, que circulou até o mês de dezembro de 1821. Em todos os números, o redator primava pela continuidade temática do que havia sido discutido nos exemplares anteriores. Já O Conciliador do Reino Unido teve apenas sete números, circulando entre $1^{\circ}$ de março e 28 de abril de 1821 .

Todas essas novas folhas, juntamente com a Gazeta do Rio de Janeiro, debateriam questões políticas essenciais da época: as Cortes, a constituição, a ideia de opinião pública e a liberdade de imprensa; esta última uma exigência dos revoltosos vintistas aceita por D. João VI no "memorável" dia 26 de fevereiro de 1821. Debater as vantagens e prejuízos da liberdade de imprensa era uma questão central da época, afinal de contas se constituía como um dos principais pilares do liberalismo político, então nascente no mundo luso-brasileiro. Cairu, que era diretor da Gazeta do Rio de Janeiro desde 1808 
e também censor régio, dedicou três números de seu jornal $O$ Conciliador do Reino Unido para pensar sobre essa problemática.

Nessas edições, criticava as ideias de um folheto anônimo impresso no Brasil que se popularizara na sociedade carioca justamente por defender a absoluta liberdade de imprensa. ${ }^{4} \mathrm{O}$ comentário do censor sobre tais reflexões é um excelente termômetro das mutações que permeavam o universo público da Corte. A "liberdade de imprensa é hoje reclamada sem limites, como direito do homem e do cidadão pela mania do século, e fantasia de sofistas, que confundem a saudável reforma com a horrorosa mudança na constituição do Estado", defendia. Com esse discurso, Cairu temia que a imprensa se convertesse em uma "maquina infernal, para explosões revolucionárias", pois, segundo ele, certamente estaria nas mãos dos pregoeiros de desordens, que, dizendo ter chegado à idade da razão, usá-la-iam para propagar erros terríveis em escritos incendiários. Em outras palavras, o nobre desejava criar limites para a liberdade de expressão. Ovídio Saraiva de Carvalho e Silva, bacharel formado em direito pela Universidade de Coimbra, também ajuizava sobre o futuro da imprensa no Brasil, principalmente depois do decreto de 2 de março de 1821 que suspendia a censura prévia. Segundo ele, todas as conversas miúdas que invadiam os diferentes lugares de sociabilidade da Corte tinham como tema a esperança das pessoas em relação aos melhoramentos decorrentes das novas possibilidades da livre escrita (O Amigo do Rei e da Nação, n. 1, s.d: 5).

Apesar de tamanha agitação social, Carvalho e Silva interpretava o decreto de 2 de março mais como uma benesse do soberano do que como uma conquista de toda a sociedade. Por essa ótica, classificava os escritores em dois grupos bem distintos entre si: o cidadão benemérito e o criminoso. “(...) os mesmos tipos, que apontarem as virtudes, hão também [de] assinalar os delitos", defendia o fiel vassalo de D. João (O Amigo do Rei e da Nação, n. 1, s.d: 7). Na prática, porém, o Rio já vivia sob a diversidade de olhares, o que constituía um passo fundamental nas discussões sobre temas de interesse coletivo.

Apenas o Brasil o sabe, não mais se esconde o entusiasmo de seus habitantes, e sem que o medo o estorve, o sentimento avulta, a opinião se fortifica, e qual seja a vontade universal não entra em dúvida. O Bem, que a todos resultava na mudança era muito claro, muito simples para que às vistas mais grosseiras pudessem ficar oculto. A Bahia soltou o primeiro grito de Constitucional e, e seu eco, retinindo no Rio de Janeiro, encontrou a resposta em um grito semelhante.

4 Ver edições de n. ${ }^{\circ}$ S 5,6 e 7 
Apesar do partido imediato, que se nutria da miséria da Nação, e iludindo o Monarca, tentava escurecer a seus Olhos os raios da verdade; apesar dos Gênios mal fazejos, aos quais não convinha a menor variação na marcha do Governo: alguns daqueles Portugueses, a quem nada atemoriza, logo que se trata da salvação da Pátria, e alguns honrados e dignos Militares, tomam a si a Grande empresa, prestão-lhe energia, e conseguem finalmente na manhã do dia $26 \mathrm{de}$ Fevereiro realizar os seu ardentes votos com Aprovação do Benéfico Soberano

Às vistas de todos estão fixas na Administração da Causa Pública, e vêm satisfeitos, que os novos Ministros, e novas Autoridades vão confirmando a boa opinião da sua escolha, tanto mais grande ( $\mathrm{sic}$ ) quanto mais difícil na crise, em que foi feita, e da qual não devia retardar-se.

O público por justos motivos queixoso, e talvez indignado: agora que a verdade já não é crime, agora que a verdade já pode intrépida avesinhar-se ao trono o Soberano conhecerá cada vez mais, que a linguagem muito raras vezes tocou nos seus ouvidos. Não digo, que em todas as Autoridades existisse a corrupção; uma tal linguagem seria um crime seria manchar os Portugueses, e supor entre eles mais perversos, do que honrados. É certo, porém, que de grandes, e mesmo de pequenas Repartições, brotavam ordens, e emanavam planos que se o nosso Bom Rei os conhecesse, não ficariam impunes seus autores.

\section{(...)}

As nossas ideias mais livres agora, apuradas por sábias combinações, e por um sisudo critério, servirão de aperfeiçoar os costumes: as Ciências, e as Artes serão melhoradas entre nós, banida a estupidez, e o mérito exaltado. O fogo dos Gênios iluminados não será mais sufocado, e sem que transponham as balizas, que a Decência e a Razão lhes assinala, sem que fatais parcialidades os desvairem, veremos defender o justo, proscrever o injusto, e melhorando o que for bom, tornar feliz a Sociedade, enriquecê-la de bons Escritos, não só pelas Pátrias produções, mais ainda pelas traduções e ampliações daquelas com que as outras se enobrecem.

(O Amigo do Rei e da Nação, n.1, s.d.:3-7). 
N. 19.
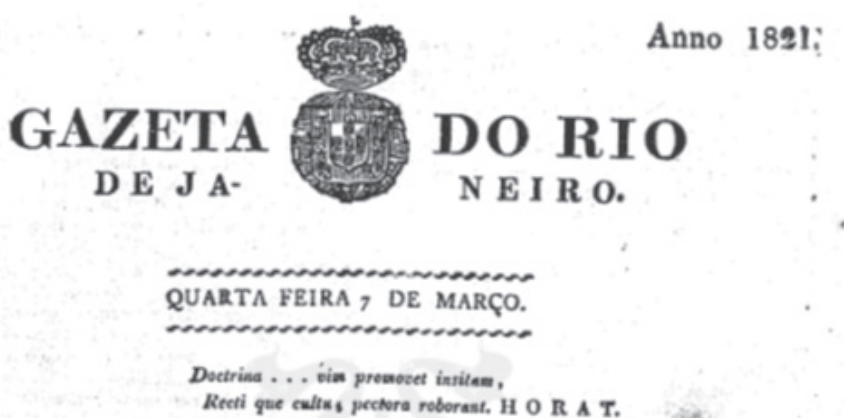

\section{RIO DE JANEIRO.}

$\mathbf{T}$ Erça feira, 6 do corrente, pelas 3. horas da tarde, us fogos de artificio, as salvas das Fortalezas e da Esq uadra, e os repiques dos si. nos advertiráo os Portugurzes de que - Ceo thes havia concedido mais hum beneficio, na feliz seccessio dos Seas Augantos Menarcas; Sua Alteza Real a Princeza Real do Reino Uni. do de Portugal, e do Bratil e Algaroes ha. vendo dado á laz buin Principe, Herdeiro das Virtudes de Seus Augustus Pais e Avós. Os nossos coraçbes, que ainda trasbordio de ju. bilo pelo fatstissimo donativo, cum que o Se. nhor D. JOXO VI., Nasso Águsto Suberano, bavia fixado a noss felicilade, toráo sobresal. sados de bum novo alvoroça, $e$ a visivel proteçáo do Altissiaso sobre Portugal exigio as nossas aç̧бes de graças. Apresiando-nos a tomar parte no publico regozijo, reiervamos por falta de tempo para- o N." seguiate a narraçio das devidas demonatrapües do apreço, que merece tão appetecido successo.

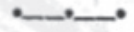

O singular Beneficio, que o Senhor D. JOXO VI., nosso Amabilissimo Soberano, concedeu aos seus ditosos Vasuallos pelo sempre memoravel Decreto de 24 de Fevereiro, ao mesmo tempo, que he o sagrado Palladio da nossa liberdade, he o matancial perenne da nosua fe. licidade. Exceeleria sem duvida as nossas aca. ahadas forças memorat todos os bens, que se derivão daquella fonte inexhaurivel. Limitando. nos porf́m a consideraçbes parciaes, temos neate momento de unencionar o Decreto de 2 de Mar. so corrente, como hutna époea notavel na his. toria Portagueza.

A liberdade da Imprensa era sem duvida huma consequencia dos principios liberaes, que havido indurido a SUA MAGESTADE a ado. ptar huma nova ordem de cousas ; mas, segundo o sentimento do celebre Montrioutea, as for. malidades da justiça sio necessarias á liberdada. SUA MAGESTADE se deliberou portanto a uncionar aquella franqueza, de que se tem derivado tantos progressos i propagaçio das lu. zes, e ́a communicaçío das noticias, Mas co* mo (segundo a opiniåo do mesmo grande Eutadista) - espirite de moderaça deve ier o do le gislador; 0 ben politice, como obem moral, se acba sempre entre dis lisiles, a sabedoria do Governo soube cohibir os excessos, que ta graves e profundas feridas tem feito na Religifio Christá, tio affastada do puro despotiamo, na opinilo do citado Autor, na moral pura do Evangelho, respeitada ainda por hum dos maio. res campióes da incredulidade, e nos principios da verdadeira politica, e da segurança pessoal, que he o mais saboroso fructo da Sociedade. Todas estas grandes vistas politicas se achio no seguinte Decreto, que offerecemos $\mathbf{a}$ attençio dos Leitores.

$$
\text { D E C R E T O. }
$$

Fazendo-se dignas de Minha Real Conside: naçlo as reiteradas Representaçbes, que Petsoas doutas e zelosas do progretso da Civilisaçio e das Letras tem feito subis a Minha Soberans 
Cinco dias depois, em 7 de março, o decreto era publicado na Gazeta do Rio de Janeiro. O comentário do redator não só admitia que a liberdade de imprensa fosse uma consequência dos princípios liberais, como também a referenciava como fator que propugnava o progresso e as luzes.

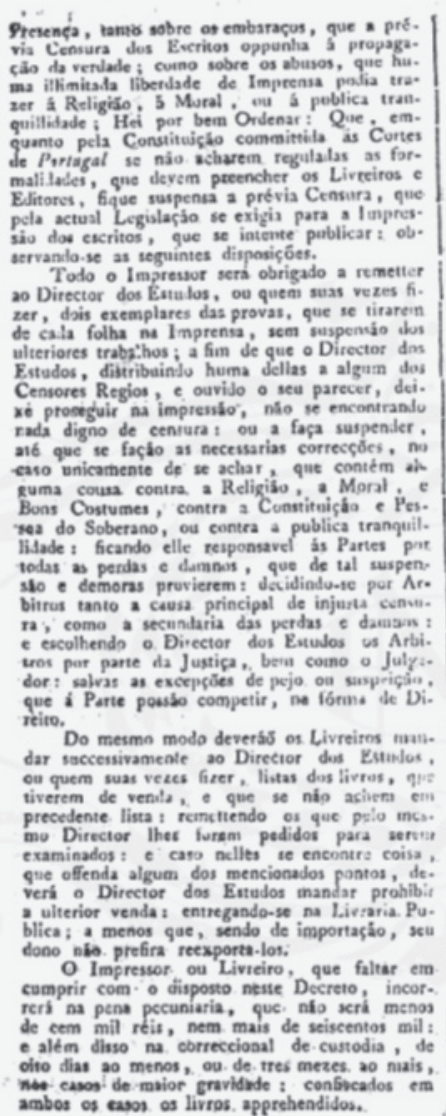

E come pelo Acto erpontaneo da Mi nh Scberania, com que Hei pur bem suspeniler at a promulgaço da Constituiça a Censura prévia. que prende e retarda a pablicaçho e cir. culaça dos Exritos, náo he, nein polis ser Minha Intença abrir a porta a libertia disoluçáo no abuso da lemprensa : Hei por espressamene declarabs, que se por alguin modo se imculuzitern nu Publico, apecar Jas cantslas. acim ondenadas, ou pela falta da sua observancia, Escritus scdiciusos, ou mbrersivos da Reliģifo e da Moral ; Gquean responsaveis is Justicas deates Meus Reinus , pela natureza e cunsequencias das dontrinas ou asserçő́es nelies conilis, em primeire lagar scus Autares: a guando estes nho sejso conhecidos, os Editores: a a final us Venjedores ou Dietribuilares, no caso que se lines prove conhecianento o cumpli. cilade na disserninaço de taes dumtrinas, ou asserç⿰⿸尸巳

A Meza do Desembargo do Paço o tenha assim enteadido, e faça executar. Palacio do Rio de Jaserire aos, de Março de 18a1. - Cora Rubrica de SUA MAGESTADE.

En consequencia do que havemos dito nos $\mathrm{N}$, ot precedentes das espontaneas e repetilas demonstraciéss de prazer, que o publico á porfí tem dado, temos a satiofaçás de accrescentur que a iltuminaçio $\mathrm{tcm}$ cuntinualo todas as neiiss, e que em tedas clias tem criado o Real Theatro de 8 . Jnd, illuminado . e se tem repetislo cum o mesmo cothusianso os Vivas i Reliziso, a SUA MAGESTADE, a S. A. R. o PIIINCIPE REAL, e i Canstituiçio em Presenca das Effigies de \$S. MM. e AA. RR. cantando-se us hymnos, e recitando-se vernos al. lovives, ta mesima maneira, que unencionimos nas Gazetas precedentes.

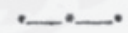

Temos muito prazer em elogiar as acerta. das medilas, com que a Pulicia tem vigiado subre a icgeranęa publica, das quacs se tará huma completa ides, lendo" a scguinte Edital.

Antonio Lurz Iratira da Cusha, do Conselbo de SUA MAGESTADE, ido da Sua Real Faresda Fidalgo da Caza Reat, Comimendadur da Orden de CArisu, Deperade da Real Jumta do Conenerrio, Ficral das Mercis, - Iniendente Giral da Policio desta Corie a Rrimo de Brasi, Es. Es. U6.

Fạo azber as que o presente Edital víg

O decreto de 2 de março transferia a censura dos manuscritos para as provas tipográficas. Isto é, na prática, mudava-se o tipo de "censura" praticada pela Coroa: regulavam-se os direitos dos editores e impressores, ao mesmo tempo em que estes ficavam restringidos à vigilância dos homens ilustrados da órbita real responsáveis pela "boa" condução das discussões. Apesar dessas controvérsias, a partir de então o Rio de Janeiro abria as portas para o florescimento da imprensa que pautaria os primeiros debates políticos na 
arena urbana. Nesse mesmo dia 7 de março, D. João notificava a decisão de voltar para Lisboa deixando aqui D. Pedro, seu legítimo sucessor que ocuparia na sua ausência o centro do poder no Brasil. Para evitar maiores conflitos políticos, que na vida cotidiana já se mostravam cada vez mais acirrados, o Rei também convocava para abril a reunião de eleitores paroquiais para a escolha de seus representantes nas comarcas, responsáveis por elegerem os deputados que comporiam as Cortes, em Lisboa.

Uma semana depois, no dia 14 de março, era estampado na primeira página da Gazeta o decreto real. A decisão da partida foi compreendida como uma prerrogativa indispensável para a manutenção do Pacto Social. Por essa razão, D. João aceitava e jurava por "toda a Nação o dever do soberano de assentar a sua residência no Lugar, onde se ajuntarem as Cortes, para lhes serem prontamente apresentadas as Leis, que se forem discutindo, e deles receberem sem delongas a Sua indispensável Sanção." Compreendia sua partida como "um dos mais custosos sacrifícios, de que é capaz o meu Paternal e Régio Coração", estendendo o momento da sua tristeza para rememorar a trajetória histórica da monarquia portuguesa, particularmente quando ele próprio fora personagem principal. Ressaltava a separação - pela segunda vez - de seus vassalos, "cuja memória me fará sempre saudosa e cuja prosperidade jamais cessará de ser em qualquer parte um dos mais assíduos cuidados do meu Paternal Governo”.

Abril foi um mês de muita tensão no Rio. As tropas de linha aguardavam com ansiedade a reunião marcada para o dia 22, que definiria os personagens ou eleitores das comarcas para a representação do Rio de Janeiro nas Cortes Gerais. Estes ameaçavam novas manifestações e, com o apoio do povo, mantinham a cidade em constante agitação, ao ponto de Silvestre Pinheiro Ferreira sugerir ao Rei que entregasse aos autores da "desordem" a sustentação da tranquilidade pública (Ferreira, 1877: 182-183). José Domingues de Attaíde Moncorco, um memorialista do período, considerava horrível o quadro da Corte nessa época. "Tal a apaga que esta cidade leal e hospitaleira recebeu daqueles a quem acolheu, elevou e nutriu por tantos anos. Ela via-se onerada de impostos mal aplicados e novos no país, sem marinha, sem comércio e sem numerário", bradava o contemporâneo. Além disso, ainda exaltava sua revolta com "uma Corte que ostentava luxo asiático; e como se ainda estes males não fossem sobejos, o Rio de Janeiro via germinar no seu seio mil partidos diversos e destrutores." Segundo ele, tais fatores foram responsáveis pela partida precipitada do Rei (Moncorvo, 1864: 274). Paralelamente, ocorria a formação das Juntas de Governos Provinciais. Pará, Pernambuco e Bahia mantinham uma posição revolucionária: os líderes expulsaram os capitãesgenerais do poder e instituíram a eleição imediata de representantes da terra. Já São Paulo e Minas Gerais compuseram o poder e a representação pela 
aliança dos antigos governadores, que simbolizavam a força do governo absolutista. Apesar das diferenças, essas transformações na recomposição dos poderes regionais significavam, nas palavras da historiadora Maria de Lourdes Viana Lyra, "a incorporação definitiva e de direito, dos nascidos no Brasil nas funções administrativas da Monarquia" que, na prática, abria o caminho para a flexibilização do sistema (1994: 196).

Diante desse cenário, D. João resolveu antecipar em um dia a reunião, que ocorreria, então, no dia 21. Entre os dias 19 e 20 eram afixados nos principais pontos da cidade os editais que determinavam a mudança da data. A antecipação do encontro foi uma estratégia muito bem planejada pelos nobres emigrados e comerciantes de grosso trato para que mantivessem o controle das decisões e impedissem ou minimizassem a presença e os votos do grupo liberal. "A leitura deste edital causou sensação prodigiosa, instruiu o povo da sua força e animou os mais tímidos. Lavrou por toda a cidade a notícia de que a junta eleitoral ia deliberar sobre um novo governo e que El-rei queria que o Brasil fixasse regido por pessoas da sua confiança", relembrava Moncorvo em maio do mesmo ano (Moncorvo, 1864: 276).

Os liberais, todavia, não acataram a alteração. Com o apoio do povo, das tropas milicianas e regimentos policiais organizaram uma manifestação na Praça do Comércio cujo intuito era fazer pressão ao governo e tentar viabilizar as diretrizes e os representantes que atendessem aos seus interesses. No dia 22, o povo - na maioria à margem do processo eleitoral -, compôs a multidão na praça. O sentido de povo no Brasil no alvorecer do Oitocentos estava estritamente associado aos critérios de representatividade, isto é, pelas regras da época vigente no quadro do liberalismo constitucional, eram as eleições censitárias e indiretas que designavam quem seriam os parlamentares. Apesar disso, o Rio ainda mantinha uma concepção tradicional do esquadrinhamento do espaço público (uma vez que as praças existiam, sobretudo devido à sociabilidade da Coroa, da nobreza, dos militares e da Igreja). Como nos elucida o pesquisador Marco Morel, essa situação já começava a mudar devido às ocorrências e "tentativas de apropriação de outros espaços, que assim se tornavam híbridos", pois marcava a presença de diferentes camadas da população na cena pública, $o$ que, na prática, contribuía decisivamente para o "movimento de passagem para a condição de súditos-cidadãos" (Morel, 2005: 165).

Ao contrário do que imaginavam os liberais, a população livre das mais diversas camadas sociais também intervinha nas propostas políticas exigindo que suas vozes e interesses fossem contemplados. Depois de lido o edital, o povo se convenceu de que tinha o direito de fazer os comentários e reflexões que melhor lhes conviessem, por isso pediram em uma voz uníssona "Queremos a constituição espanhola interinamente!" (Moncorvo, 
1864: 277), que vigorava desde 1812 e cujo texto exercia grande influência no desenvolvimento do constitucionalismo espanhol, português e também norte-americano.

Esse posicionamento mostrava um viés fundamental da atuação do "povo" tão subestimado pelas elites luso-brasileiras: havia uma insubordinação às decisões e aos projetos políticos defendidos pela elite proprietária de terras, o que representava um perigo para os grupos em conflito, fossem eles a alta nobreza portuguesa e os ricos negociantes fluminenses, ou mesmo o grupo dos ditos liberais.

Em meio ao rebuliço, os membros do partido realista ou os homens próximos à $\mathrm{D}$. João pediam tranquilidade e admitiam o juramento à constituição espanhola. "Os clamores aumentando em todo o salão, muitos membros da junta tomaram a palavra para os sossegar (sic), e os eleitores mais adictos às novas opiniões, depois de terem apreciado em silêncio o espírito do seu corpo, vendo que o partido realista estava comprimido por um terror pânico julgaram chegada a ocasião de se aproveitarem do ardor popular: eles em alta voz pediam ao povo que se tranquilizasse, prometendo-lhes que se havia de julgar a constituição que pediam, e afiançando o presidente para que estava munido de poderes reais para os atender", narra Moncorvo, uma figura ocular dos fatos.

A violência e o acirramento das diferentes posições políticas alteraram os rumos da reunião. No auge das discórdias, D. Pedro autorizou a atuação repressiva das tropas de linha e de regimento da divisão portuguesa que colocavam um ponto final à manifestação. $\mathrm{O}$ saldo de tamanha violência, no entanto, era um alto número de mortos e feridos. “(...) pessoas do povo foram indiscriminadamente mortas, e um número maior, lançando-se ao mar com precipitação, encontrou nas ondas a morte que evitava. Porém, $\mathrm{o}$ que mais denegria estes soldados desencaminhados e ferozes foi que, não contentes de tirarem a vida a seus próprios concidadãos, traficavam nelas, recebiam ou roubavam o que achavam de mais precioso, e saquearam os móveis de prata do serviço da casa", descrevia o mesmo memorialista (Moncorvo, 1864: 288).

A grande repercussão do episódio teve diferentes versões pela cidade. Cada um a sua maneira recontava o fato ressaltando os detalhes que mais lhe interessavam. Diante de tamanha afronta ao poder real, era necessário que o gazeteiro da monarquia publicasse uma reportagem sobre o ocorrido, em 25 de abril. Depois de descrever a razão do evento ocorrido na Praça do Comércio - a eleição dos nomes dos compromissários para atuação nas Cortes -, Araújo Guimarães falava em nome da monarquia, comentando a enorme decepção que o povo havia causado diante dos olhos do Rei e seus representantes. "Confessamos ingenuamente que nos entregávamos 
de antemão a sentimentos de júbilo por uma acizada (sic) eleição, e nos felicitávamos do desempenho de tão grato dever. Mas quanto são errados (sic) os juízos dos homens!" Afirmava ainda que, por ter as esperanças malogradas, a dor era pungente. Ressaltava, contudo, que "devemos ser fiéis expositores de acontecimentos desastrados, que tiveram origem na inconsideração, progresso na exaltação de sentimentos ilegais, e fim em desgraças, que a maior vigilância não pudera antever."

A circunstância pela ótica das autoridades reais era desastrosa e a fala do redator deixava claro que a razão dessa catástrofe tinha uma explícita relação com a atuação do povo - considerado por Guimarães "inimigos da causa pública" -, justamente porque reivindicava a sua participação política. Segundo o jornalista, os revoltosos "sofregamente procuravam medidas violentas, e providências arrebatadas. Discursos sediciosos, vozes tumultuosas substituíram a tranquilidade e sangue frio necessários em deliberações de tanta importância" que acabaram por abrir espaço para objetivos "alheios àquela assembléia e, portanto nulos". Para os representantes da monarquia, esses personagens acabaram por produzir muitos rumores anárquicos ao invés de consagrar o importante voo em direção à liberdade, o que causava profundo pesar aos cidadãos que têm verdadeiro amor pela Pátria.

A reflexão publicada na folha oficial três dias depois do episódio revelava muito da visão que os detentores do poder possuíam dos agentes sociais populares que estavam inseridos na transformação política de tamanha envergadura para os destinos do Império luso-brasileiro. Compunham uma multidão ainda sem coesão coletiva em prol dos ideais que defendiam, mas que já possuíam a consciência do seu potencial de transformação ou, ao menos, já começavam a compreender a força inerente ao poder de suas palavras quando expunham as contradições e problemas da realeza no espaço público.

Em 26 de abril, quatro dias após esse episódio lamentável, D. João VI partia para Portugal. D. João, a Rainha D. Carlota e o príncipe D. Miguel eram acompanhados por mais ou menos quatro mil pessoas que compunham a comitiva real. Por ironia do destino, o regresso da corte joanina foi feito à francesa, às pressas, mas sem alarde. D. João VI voltava para o Reino muito menos Rei do que quando chegara ao Brasil, ainda Príncipe Regente. Acuado politicamente, o silêncio da partida demonstrava o medo do monarca diante das possíveis manifestações populares que já faziam parte do cotidiano de seus súditos-cidadãos em ambas as margens do imperial Atlântico português.

Dois dias depois da partida, a edição 34 da Gazeta do Rio de Janeiro estampava a notícia que já era de conhecimento de todos na cidade. $\mathrm{O}$ jornalista exaltava as provas de amor do soberano aos seus vassalos e todo o seu empenho em prosperar o Novo Mundo. O embarque da realeza 
pela nau D. João VI era descrito da seguinte forma: "Um excelente dia, um vento do NE, fresco e aturado fizeram sobressair esta cena brilhante, e ao mesmo tempo dolorosa”. Nessa mesma edição, a Gazeta publicava o primeiro artigo de D. Pedro na imprensa. Intitulado Habitantes do Brasil, o regente comunicava seus súditos acerca dos objetivos gerais de sua real administração. Em 28 de abril de 1821, portanto, sob as rédeas do Príncipe Regente, que ficara para dar unidade ao Império, começava uma importante fase da história do Brasil. O período joanino ficara para trás. 


\section{Considerações Finas}

A volta de D. João VI para a Europa marcava o final de um período ímpar na História da colonização do Novo Mundo. Pela primeira vez um monarca atravessou o oceano, pisou em suas possessões coloniais, transladou - com sua corte - uma estrutura governamental para o outro lado do Atlântico e foi aclamado Rei com toda a pompa das cortes europeias.

No entanto, ao retornar para o Velho Continente, D. João VI partia muito menos Rei do que quando aqui chegara. Nos treze anos em que permaneceu no Brasil a face política do mundo luso-brasileiro se transformara a ponto de colocar em questão a natureza de seu pátrio poder. Se em Portugal desde a Revolução do Porto (1820) os súditos-cidadãos exigiam a regeneração da pátria, com a promulgação de uma Constituição pelas Cortes que assentaria o poder político do Rei em uma monarquia constitucional, deste lado do Atlântico o diálogo e a tensão política com o Reino não foram menores.

A partir de 1821, os ecos da Revolução do Porto já se faziam presente no espaço público do Brasil, sobretudo no Rio de Janeiro. Os conflituosos interesses da elite brasileira colocavam em cena as disputas pela vigência de diferentes projetos políticos que apareciam de forma patente na dinâmica da vida cotidiana. A arena pública se tornava palco da constituição da prática cidadã e o homem comum passava a refletir e a discutir os destinos do Brasil. O povo emergia como personagem de primeiro escalão na teatralidade da vida política e era agora necessário que os representantes do poder se preocupassem em criar formas mais sofisticada de controle das possíveis consequências políticas desses indivíduos no espaço público.

Atos e palavras ganhavam novos significados. Resultado da complexidade de um universo plural em que os códigos de sociabilidade tradicionais do Antigo Regime se conflitavam com os novos valores e posturas políticas que constituíam uma sociedade em constante mutação. 


\section{Bibliografia Comentada}

ALGRANTI, Leila Mezan, O feitor ausente. Estudo sobre a escravidão urbana no Rio de Janeiro (1808-1822). Petrópolis: Vozes, 1988.

Este livro é uma contribuição fundamental para a compreensão da escravidão urbana no Brasil uma vez que discute as relações socioeconômicas escravistas vigentes na cidade do Rio de Janeiro no período joanino. A autora reinterpreta a natureza e as feições características do escravismo colonial sob a forma de ganho, que marca as peculiaridades do sistema escravista no universo urbano, intrinsecamente associado à sustentação do Estado português no Brasil Colonial. A obra também fornece importantes subsídios para a compreensão da história da vida cotidiana carioca no raiar do século XIX, marcada por tensões, violências e conflitos sociais inseridos em um movimento mais amplo das contradições escravistas vigentes no sistema colonial brasileiro.

KURY, Lorelai (Org.), Imperialismo e Império no Brasil. O Patriota (18131814). Rio de Janeiro: Editora Fiocruz, 2007.

Coletânea de cinco artigos de renomados historiadores nacionais, o livro traz análises inovadoras que discute as singularidades do que os pesquisadores denominaram de iluminismo luso-americano, que nasceu inserido no universo imperial português. Sob diferentes problematizações, os autores buscaram compreender as especificidades inerentes ao processo de produção, discussão, circulação e leitura das ideias impressas no universo letrado da Colônia, presente nas páginas de O Patriota, primeiro jornal literário e científico a circular no Brasil nos anos de 1813 e 1814. O leitor ainda recebe o CD-ROM com a coleção integral de O Patriota, que permite o acesso ao fac-símile da coleção de textos raríssimos produzidos por homens ilustrados da seleta órbita cultural do monarca.

LOPES, Emilio Carlos Rodrigues, Festas Publicas, Memória e Representação: um estudo sobre manifestações na Corte do Rio de Janeiro (1808-1822). São Paulo: Ed. Humanitas FFLCH/USP, 2004.

Os sentidos políticos das festas produzidas pela monarquia portuguesa entre os anos de 1808 e 1822 norteiam a discussão deste livro, que é uma referência importante para a compreensão da vida sociocultural do período joanino no Brasil. Ao analisar a arquitetura das festas sob o olhar de diversos 
personagens da época, o autor traça um rico cenário dos diferentes olhares e interesses na constituição desses eventos sociais, intrinsecamente relacionados à ideia de sustentação do Império Português. Sob essa perspectiva, o livro aborda dois eventos de suma importância do período: a aclamação de D. João VI, em 1818, e a aclamação de D. Pedro I, em 1822. A dimensão da análise ganha relevância em virtude do amplo significado que apresentaram dentro do momento histórico que problematizava os confrontos vigentes no movimento de separação dos Reinos do Brasil e Portugal.

LIMA, Oliveira, D. João VI no Brasil. $4^{\mathrm{a}}$ ed. Rio de Janeiro: Topbooks. 2006.

Livro clássico da historiografia brasileira, D. João VI no Brasil completa cem anos mantendo uma análise atual acerca da problemática política vigente no período joanino. Ao consultar uma ampla documentação diplomática, o autor não só revela uma imagem complexa de D. João como Príncipe Regente e monarca como também enfatiza a figura de Carlota Joaquina. A análise dos bastidores da política ministerial do governo joanino assim como as tensões, interesses políticos e práticas da vida cotidiana, ambos ricamente contextualizados, são o ponto alto dessa obra, cuja narrativa envolvente coloca o leitor diante de complexidade do universo político imperial e cotidiano da sociedade carioca.

MALERBA, Jurandir. A corte no exílio: civilização e poder às vésperas da independência (1808-1821), São Paulo: Cia das Letras, 2000.

O enfoque sociocultural da vinda da Corte para o Brasil é um dos aspectos mais inovadores da obra de Jurandir Malerba. Ao analisar o impacto da instalação da Família Real no Rio de Janeiro e as consequências para a formação de uma nova sociedade na América, ainda nos moldes do Antigo Regime Português, o historiador traça um panorama das mudanças e permanências ocorridas entre anos de 1808 e 1821. O sentido das festas e do teatro na formação da constituição de um novo espaço público assim como a importância da sociabilidade de cortesão no intricado jogo político das disputas políticas da corte, entre nobres portugueses e comerciantes fluminenses são detalhadamente enfocados. Ao considerar os múltiplos aspectos do nascimento de um novo universo político, Malerba faz uma analise pertinente da formação do Estado Brasileiro como nação independente. 
SILVA, Maria Beatriz Nizza da. Gazeta do Rio de Janeiro (1808-1822): Cultura e Sociedade: Rio de Janeiro: Eduerj: 2007.

Ao utilizar a seção de Anúncios da Gazeta do Rio de Janeiro como fonte documental do período joanino, o livro reconstitui de forma inovadora a vida sociocultural e política da época. Por uma análise pormenorizada da sociabilidade nos seus múltiplos vieses, o leitor tem a oportunidade de conhecer aspectos fundamentais do cotidiano no Rio de Janeiro, entre os anos de 1808 e 1822, que apareciam pelas páginas do jornal oficial. Dos hábitos alimentares e diferentes tipos de moradia às doenças e os modos de curar. A diversidade dos grupos socioprofissionais, as práticas comerciais assim como as práticas de leitura da sociedade da época são temas, particularmente enfocados. Mas a análise da autora vai mais além: ao tratar também das notícias políticas publicadas no periódico em profundidade, a obra se incorpora à historiografia como uma referência indispensável para o conhecimento mais amplo do período.

D. JOÃO NA CORTE DO RIO DE JANEIRO - CRONOLOGIA

1808

- 8 de março, D. João desembarca no Rio de Janeiro.

- Criação do Conselho de Estado.

- Criação do Conselho da Fazenda.

- Criação do Conselho Supremo Militar e de Justiça por alvará de o1/4.

- Estabelecimento da Real Academia dos Guardas Marinha, no Rio de Janeiro por alvará de $05 / 5$.

- Criação do Tribunal da Mesa do Desembargo do Paço e da Consciência e Ordens no Rio de Janeiro por alvará de 10/5.

- Criação da Intendência Geral da Polícia da Corte e do Estado do Brasil, por alvará de $10 / 5$.

- Elevação do Tribunal da Relação à categoria de Casa da Suplicação do Brasil, por alvará de 10/5.

- Elevação à primazia de Capela Real a Igreja de Nossa Senhora do Monte Carmelo no Rio de Janeiro e criação da Paróquia do Paço Real.

- Criação do Arsenal da Marinha e da Escola da Marinha.

- Criação do Regimento de Cavalaria.

- Abolição da proibição de instalação de fábricas no Brasil e em todos os domínios ultramarinos por alvará de $28 / 5$.

- Regulamentação da fábrica de pólvora por decreto de 13/5. 
- Estanco das cartas de jogar do Brasil e dos domínios ultramarinos por alvará de $28 / 5$.

- Criação da Real Junta do Comércio, Agricultura, Fábricas e Navegação por alvará de $23 / 8$.

- Determinação para circulação de moedas de ouro, prata e cobre e proibição de ouro em pó, por alvará de o1/9.

- Fundação do Banco do Brasil por alvará de 12/10.

- Declaração de completa liberdade de circulação de moeda no Brasil por alvará régio.

- Criação da Escola de Cirurgia do Hospital Militar em Salvador por decreto de $18 / 2$.

- Criação do Museu Real no Rio de Janeiro, por decreto de 6/6.

- Criação da Escola Anatômica Cirúrgica e Médica do Hospital Militar do Rio de Janeiro, por decreto de 5/11.

- Início da circulação da "Gazeta do Rio de Janeiro" periódico oficial do governo, em setembro.

- Manifesto do Príncipe Regente, D. João, declarando guerra à França (1/5). 1809

- Início das atividades do Banco do Brasil em 11/12.

- Início das atividades da Impressão Régia no Rio de Janeiro.

1810

- Criação da Academia Real Militar no Rio de Janeiro por carta régia de 4/2. (Aberta em 1811)

- Assinatura entre Portugal e Inglaterra dos tratados de Comércio e Amizade e de Aliança e Navegação (19/2). Assinados por Lord Strangford e D. Rodrigo de Souza Coutinho.

- Chegada da primeira leva da Livraria do Rei e da Livraria do Infantado. São livros, manuscritos, códices, incunábulos, estampas, desenhos originais e mapas. Chegam também aparelhos científicos e uma coleção de moedas e medalhas.

- Instalada a Real Biblioteca no andar superior do Hospital da Ordem Terceira do Carmo.

1811

- Abertura da Academia Real Militar, criada em 1810.

- Criação da Junta da Fazenda, Arsenais, Fábricas e fundições do Rio de Janeiro.

- Abertura da Real Biblioteca. 
- Com o bibliotecário Luís Marrocos chega ao Rio de Janeiro o segundo lote de livros da Real Biblioteca (junho). Em novembro, com José Lopes Saraiva, chegam "os últimos 87 caixotes de livros", segundo carta de Marrocos a seu pai. 1813

- Inauguração do Teatro São João no Rio de Janeiro.

- Criada a Escola Cirúrgica, com sede no Hospital da Misericórdia.

1814

- Napoleão é deposto. Luís XVIII ocupa o trono.

- Convenção, assinada em Paris, entre a França, Inglaterra, Portugal, Áustria, Prússia e Rússia, sobre a suspensão de hostilidades (23/4); a que se refere o Ato de Adesão de D. João (8/5)

1815

- Carta de Lei que cria o Reino Unido de Portugal e do Brasil e de Algarves (16/12) ou, elevação do Brasil a Reino Unido a Portugal e Algarves, por carta régia de 16/12.

1816

- Morte de D. Maria I e início do Reinado de D. João VI.

- Chegada da Missão Artística Francesa chefiada por Lebreton.

- Criação da Escola Real de Ciências, Artes e Ofícios.

1817

- Desembarque de D. Leopoldina no Rio de Janeiro / Casamento.

1818

- D. João VI promove a cerimônia de sua aclamação.

1820

- Revolução Constitucionalista do Porto. As cortes de Lisboa exigem a volta de D. João a Portugal e formam uma Junta Provisional do Governo Supremo do Reino com o objetivo de tomar a regência e adotar uma Constituição. - Fundação da Academia das Artes do Rio de Janeiro por decreto de 23/11.

- Chegada de João Maurício Rugendas ao Brasil (permanecendo até 1830). 1821

- Família real regressa definitivamente a Portugal. Com ela retornam 4000 indivíduos: ministros, oficiais, diplomatas e suas famílias, além dos deputados que iam à Corte. 
- D. Pedro assume a regência do Reino do Brasil (26/4).

- Extinção do Tribunal do Santo Ofício.

- Abolição da Censura prévia e regulamentação do exercício da liberdade de imprensa, por decreto. (Em Portugal)

- Convocação dos deputados para as Cortes de Lisboa.

- Ordem para retorno de D. Pedro a Portugal / Processo de emancipação.

(Fonte: http://www.rio.rj.gov.br/culturas/anexos/djoao_cronologia.pdf) 


\section{Fontes e ReFERÊNCIAS BibliográficAs}

Fontes Impressas e Manuscritas

Carta de hum fiel vassallo a El rei D. João VI, relatando o estado do reino de Portugal sob o governo regencial e pedindo a volta se S. M. Documentos para a História da Independência, 1923.

[Carta] Regitrada nesta Secretaria de Estados dos Negócios do Brasil, L. ${ }^{\circ} 2 .^{\circ}$ de leis, alvarás, e Cartas Régias à fl.69. Rio de Janeiro, em 16 de dezembro de 1815 .

Biblioteca Nacional do Rio de Janeiro

Cartas de C. de Geine ao Intendente da Polícia.. 2 de janeiro 1821. Divisão de Manuscritos, II-33, 22, 54.

MORAES, Alexandre José de Melo, Dados sobre a chegada ao Rio de Janeiro da Família Real, problemas de habitação para a comitiva, vida social e política, hábitos da família real, volta para Portugal, falecimento de D, João VI e Pedro I como imperador, S.l, s.d, Original (transcrição feita por Cecília Coelho, maio de 2001). Divisão de Manuscritos, II-30, 23, 6,7.

Relação das festas que se fizeram no Rio de Janeiro, quando o príncipe Regente N.S e toda a sua família chegarão pela primeira vez áquella capital. Ajuntando-se algumas particularidades igualmente curiosas, e que dizem respeito ao mesmo objeto. Lisboa, Impressão Régia, 1810. Seção de Obras Raras, $[36,0,21]$

Ferreira. Seção de Obras Raras - DOC 37,5 1B.

Poesia em aplauso dos heróicos feitos do memorável dia 26 de fevereiro 1821, Rio de Janeiro, Imprensa Régia, 1821.

Arquivo Nacional da Torre do Tombo (Portugal)

Casa Forte, Ministério dos Negócios Eclesiásticos e da Justiça, M.22, fl.204. 
Ministério do Reino, Governadores do Reino, Registro de Cartas ao Príncipe Regente, Livro 317, Carta 466, 17.3.1817, fl.377.

Ministério do Reino, Livro 325.

Biblioteca Nacional de Lisboa

Memória sobre a Conspiração de 1817 , vulgarmente chamada $A$ Conspiração Gomes Freire; escrita e publicada por um português, amigo da justiça e da verdade, Lisboa, Imprensa Liberal, 1822.

Relação dos Acontecimentos do Rio de Janeiro no dia 26 de fevereiro de 1821 e algumas circunstâncias que o precederam e o produziram. Seção de Reservados, Cód. 10.759.

Lisboa. Punhal dos Corcundas. n. ${ }^{\circ}$ 5, p.41. Lamentos políticos de um pobrezinho e preguiçoso que estava acostumado a manter-se à custa alheia, por O lamentador.

\section{DOCUMENTOS IMPRESSOS}

“Considerações sobre o Estado de Portugal e do Brasil, desde a saída d'El Rei de Lisboa em 1807 até o presente, indicando algumas providências para a consolidação do Reino Unido", Londres, 4 de Junho de 1822, In: RIHGB, tomo XXVI, 1863, p. 147.

FERREIRA, Silvestre Pinheiro, Memórias e Cartas Biográficas, sobre a Revolução Popular e o ministério do Rio de Janeiro desde 26 de fevereiro de 1821 até o regresso de S.M O Sr. D. João VI com a Corte para Lisboa e os votos de homens de Estado que acompanharam S.M.( $2^{\text {a }}$ Parte $)$ Anais da Biblioteca Nacional.Volume III, (fascículo I) Rio de Janeiro, Leuzinger e Filhos, 1877, Carta XXII, p.182-183.

MONCORVO, José Domingues de Attaíde. "Sobre os acontecimentos dos dias 21 e 22 de Abril de 1821 na Praça do Comércio do Rio de Janeiro. Escrita em Maio do mesmo ano por uma testemunha presencial", in Revista Trimensal do Instituto Histórico Geográfico e Etnográfico do Brasil, tomo XXVII, parte primeira, Rio de Janeiro, Tipografia Luis dos Santos, 1864.

PONDÉ, Francisco de Paula e Azevedo. "D João VI e a emancipação intelectual do Brasil”, in RIHGB. Rio de Janeiro, tomo 279, 1968.

VIANA, Paulo Fernandes. "Abreviada Demonstração dos trabalhos da Polícia em todo o Tempo que serviu o Desembargador do Paço Paulo Fernandes Viana", RIHGB, tomo 55, parte.1, 1892, p. 374-375. 
PerióDicos

Gazeta do Rio de Janeiro (1808-1821)

O Bem da Ordem (1821)

O Conciliador do Reino Unido (1821)

O Amigo do Rei e da Nação (1821)

Livros, Artigos e Teses

ALGRANTI, Leila Mezan. O feitor ausente. Estudo sobre a escravidão urbana no Rio de Janeiro (1808-1821). Petrópolis: Ed. Vozes, 1988.

ALGRANTI, Leila Mezan. Livros de Devoção, Atos de censura: cultura religiosa na América Portuguesa, Ed. Hucitec e Fapesp, São Paulo, 2004.

ASSUNÇÃO, Paulo de. Ritmos da Vida: momentos efusivos da família real portuguesa nos trópicos. Rio de Janeiro. Ed. Arquivo Nacional, 2008.

BITTENCOURT, José Neves, "Iluminando a Colônia para a Corte: o museu real e a Missão Francesa como marcos exemplares da política de administração portuguesa no Brasil", in Seminário Internacional Dom João VI: um rei aclamado na América, Rio de Janeiro, Museu Histórico Nacional, 2000.

CAMARGO, Ana Maria de Almeida; MORAES, Rubens Borba de. Bibliografia da Impressão Régia do Rio de Janeiro, Edusp, São Paulo, 1993.

DEBRET, Jean, Baptiste. Viagem pitoresca e histórica do Brasil. Trad. e Notas Sérgio Milliet. Belo Horizonte/ São Paulo: Itatiaia/Edusp, 1989.

Diccionário BioBibliográphico brasileiro de diplomacia, política externa e direito internacional Argeu Guimarães: Rio de Janeiro: Edição do autor, 1938.

KLEIN, Herbert. The middle passage. Princeton: Princeton University Press, 1978.

KURY, Lorelai (Org.). Imperialismo e Império no Brasil. O Patriota (18131814). Rio de Janeiro: Editora Fiocruz, 2007.

LIMA, Madalena Q. Aspectos da vida cotidiana do Rio de Janeiro na visão de três viajantes estrangeiros: Debret, Rugendas e Maria Graham. Dissertação de mestrado. UERJ. 2000.

LIMA, Oliveira. D. João VI no Brasil. $3^{\text {a }}$ ed. Rio de Janeiro. Topbooks, 1996. LYRA, Maria de Lourdes Viana. A utopia do poderoso império. Portugal e Brasil: bastidores da política (1798-1822). Rio de Janeiro: Sette Letras, 1994.

LOPES, Emílio. Festas públicas, memórias e representação: um estudo sobre manifestações na Corte do Rio de Janeiro (1808-1822). São Paulo: Ed. Humanitas FFLCH/USP, 2004. 
LUCCOCK, John. Notas sobre o Rio de Janeiro e partes meridionais do Brasil, tomadas durante uma estada de dez anos nesse país, de 1808 a 1818, Trad. Milton da Silva Rodrigues, São Paulo, Livraria Martins, 1942.

LUCCOCK, John. Notas sobre o Rio de Janeiro e partes meridionais do Brasil. Belo Horizonte: Ed. Itatiaia, 1975.

MALERBA, Jurandir. A corte no exílio: Civilização e poder no Brasil às vésperas da Independência (1808-1821), Cia das Letras, São Paulo, 2000.

MARTINS, Ismênia de Lima. "Corte Joanina”. In: NEVES, Lúcia Bastos Pereira das; VAINFAS, Ronaldo. Dicionário do Brasil Joanino. Rio de Janeiro: Objetiva, 2008.

MEIRELLES, Juliana Gesuelli, Imprensa e poder na corte joanina: A Gazeta do Rio de Janeiro. Ed. Arquivo Nacional: Rio de Janeiro, 2008.

NEVES, Lúcia M. Bastos Pereira das. As representações napoleônicas em Portugal: imaginário e política (1808-1810). Tese para Professor Titular em História Moderna. UERJ. Rio de Janeiro. 2002.

NEVES, Lúcia M. Bastos Pereira das, Corcundas e Constitucionais: a cultura política da independência (1820-1822), Revam: FAPERJ, Rio de Janeiro, 2003.

NORTON, Luiz. A corte de Portugal no Brasil. São Paulo. Companhia Editora Nacional. 1938.

SANTOS, Afonso Carlos Marques dos. "A fundação de uma Europa possível" in Seminário Internacional Dom João VI: um rei aclamado na América, Rio de Janeiro, Museu Histórico Nacional, 2000.

SANTOS, Luiz Gonçalves dos Santos, Memórias para servir à história do Brasil. Lisboa. Impressão Régia. T.1. 1825.

SCHWARCZ, Lilia M., AZEVEDO, Paulo César de e COSTA, Ângela Márquez da. A longa viagem da biblioteca dos reis: do terremoto de Lisboa à Independência do Brasil. São Paulo. Companhia das Letras, 2002.

SCHWARCZ, Lilia M. "Metrópole improvável de 46 ruas", in 200 anos da chegada da corte: um império nos trópicos. O Estado de São Paulo. 7 de março de 2008.

SCHWARCZ, Lilia M. O sol do Brasil: Nicolas Antoine Taunay e as desventuras artísticas dos artistas franceses na corte de D. João. São Paulo: Companhia das Letras. 2008.

SILVA, Maria Beatriz Nizza da. Gazeta do Rio de Janeiro (1808-1822): Cultura e Sociedade: Rio de Janeiro: Eduerj, 2007.

SILVA, Maria Beatriz Nizza da. Dicionário da História da Colonização Portuguesa no Brasil, Lisboa: Ed. VERBO, 1994.

SILVA, Maria Beatriz Nizza da. Livro e Sociedade no Rio de Janeiro (18081821). Separata da Revista de História, n. ${ }^{\circ} 94$, São Paulo, 1973. 
SILVA, Paula Pinta. "Angu e empada, aipim e avelâ", in 200 anos da chegada da corte: um império nos trópicos. O Estado de São Paulo. 7 de março de 2008.

SCHIAVINATTO, Iara Lis. Pátria Coroada: o Brasil como Corpo Político Autônomo 1780-1831, Ed. Unesp, São Paulo, 1999.

SOUZA, Laura de Melo e (Org.). História da Vida Privada no Brasil: Cotidiano e vida privada na América Portuguesa. São Paulo: Companhia das Letras: 1997. 